This document is confidential and is proprietary to the American Chemical Society and its authors. Do not copy or disclose without written permission. If you have received this item in error, notify the sender and delete all copies.

\title{
A Thieno[2,3-d]pyrimidine Scaffold is a Novel Negative Allosteric Modulator of the Dopamine D2 Receptor
}

\begin{tabular}{|r|l|}
\hline Journal: & Journal of Medicinal Chemistry \\
\hline Manuscript ID & jm-2017-01565m.R2 \\
\hline Danuscript Type: & Article \\
\hline Complete List of Authors: & $\begin{array}{r}\text { Fyfe, Tim; Monash Institute of Pharmaceutical Sciences, Medicinal } \\
\text { Chemistry } \\
\text { Zarzycka, Barbara; University of Southern California } \\
\text { Lim, Herman; Monash Institute of Pharmaceutical Sciences, Drug Discovery } \\
\text { Biology by the Author: } \\
\text { Kellam, Barrie; University of Nottingham, School of Pharmacy } \\
\text { Mistry, Shailesh; University of Nottingham, Pharmacy } \\
\text { Katritch, Vsevolod; University of Southern California, BISC } \\
\text { Scammells, Peter; Monash University, Medicinal Chemistry } \\
\text { Lane, J. Robert; Monash Institute of Pharmaceutical Sciences, Drug } \\
\text { Discovery Biology } \\
\text { Capuano, Ben; Monash Institute of Pharmaceutical Sciences, Medicinal } \\
\text { Chemistry }\end{array}$ \\
\hline
\end{tabular}

\section{SCHOLARONE}

Manuscripts 


\section{A Thieno[2,3- $d]$ pyrimidine Scaffold is a Novel Negative Allosteric Modulator of the Dopamine $\mathrm{D}_{2}$ Receptor}

Tim J. Fyfe, ${ }^{\dagger},, / /$ Barbara Zarzycka, ${ }^{\ddagger}$ Herman D. Lim, ${ }^{\S}$ Barrie Kellam, " Shailesh N. Mistry, ${ }^{\prime \prime}$ Vsevolod Katrich, ${ }^{\star \neq}, \neq$ Peter J. Scammells, ${ }^{\dagger}$ J. Robert Lane, ${ }^{*, \S}$ Ben Capuano ${ }^{*} \dagger$

${ }^{\dagger}$ Medicinal Chemistry, and ${ }^{\S}$ Drug Discovery Biology, Monash Institute of Pharmaceutical Sciences, Monash University, Parkville, Victoria 3052, Australia

"School of Pharmacy, Centre for Biomolecular Sciences, University of Nottingham, Nottingham NG7 2RD, U.K

${ }^{\ddagger}$ Department of Biological Sciences, Bridge Institute, University of Southern California, Los Angeles, CA 90089, United States.

FDepartment of Chemistry, Bridge Institute, University of Southern California, Los Angeles, CA 90089, United States.

Abstract: Recently, a novel negative allosteric modulator (NAM) of the $\mathrm{D}_{2}$-like dopamine receptors 1 was identified through virtual ligand screening. This ligand comprises a thieno[2,3- $d]$ pyrimidine scaffold that does not feature in known dopaminergic ligands. Herein, we provide pharmacological validation of an allosteric mode of action for $\mathbf{1}$, revealing that it is a NAM of dopamine efficacy and identify the structural determinants of this allostery. We find that key structural moieties are important for functional affinity and negative cooperativity, whilst functionalization of the thienopyrimidine at the 5- and 6-positions results in analogues with divergent cooperativity profiles. Successive compound iterations have yielded analogues exhibiting a 10fold improvement in functional affinity, as well as enhanced negative cooperativity with dopamine affinity and efficacy. Furthermore, our study reveals a fragment-like core that maintains low $\mu \mathrm{M}$ affinity and robust negative cooperativity with markedly improved ligand efficiency.

\section{- INTRODUCTION}

The dopamine $D_{2}$ receptor $\left(D_{2} R\right)$, a class $A$ G protein-coupled receptor (GPCR), is a therapeutic target for central nervous system disorders such as schizophrenia and Parkinson's disease. Accordingly, it has been the subject of intensive drug discovery efforts for the last 60 years. Such efforts have focused on targeting the 
orthosteric binding site of the $\mathrm{D}_{2} \mathrm{R}$ where dopamine (DA) binds. ${ }^{1,2}$ Clinically marketed drugs indicated for the treatment of schizophrenia display efficacy with respect to treating the positive symptoms of the disease. These drugs all act either as competitive antagonists or partial agonists at the $\mathrm{D}_{2} \mathrm{R}$. However, these drugs can cause deleterious side-effects. First-generation antipsychotics (FGAs) are associated with a high frequency of extrapyramidal motor symptoms (EPS) caused by antagonism of $\mathrm{D}_{2} \mathrm{R}$ signaling in the nigrostriatal system. ${ }^{3}$ Although, second generation antipsychotic (SGAs) are thought to be associated with a lower risk of EPS such drugs are associated with other limiting side effects such as metabolic side effects. ${ }^{4}$

In order to adequately address the unmet medical need associated with antipsychotic drug discovery, novel approaches are required. NAMs that display limited negative cooperativity with dopamine have been proposed as a safer therapeutic option to treat the positive symptoms of schizophrenia, in particular for the onset of EPS, because they would cause only partial blockade of the $\mathrm{D}_{2} \mathrm{R} .{ }^{5}$ Indeed, targeting allosteric sites within GPCRs may be associated with a number of advantages over classical orthosteric drug discovery such as improved subtype-selectivity and thus reduced off-target side-effects, as well as maintenance of spatiotemporal patterns associated with endogenous neurohumoral signalling because they still allow the endogenous neurotransmitter to bind the receptor. ${ }^{6,7}$

Virtual screening of orthosteric and putative allosteric sites within the human dopamine $\mathrm{D}_{3}$ receptor $\left(D_{3} R\right)$ recently identified an active thienopyrimidine compound (1, Figure 1$) .{ }^{8}$ In this study, screening was undertaken using two optimised crystal-structure-based models (PDB ID: 3PBL) ${ }^{9}$ : the receptor with an empty (unliganded) binding pocket $\left(\mathrm{D}_{3} \mathrm{R}^{\mathrm{APO}}\right)$, and the receptor complex with $\mathrm{DA}\left(\mathrm{D}_{3} \mathrm{R}^{\mathrm{Dopa}}\right)$. In particular, $\mathrm{D}_{3} \mathrm{R}^{\mathrm{Dopa}}$ was used to screen for allosteric compounds that can bind along with the endogenous ligand. Interestingly, $\mathbf{1}$, although identified using $\mathrm{D}_{3} \mathrm{R}^{\mathrm{APO}}$, was predicted to bind in an allosteric pose and showed the highest potency of DA inhibition in vitro. ${ }^{8}$ Furthermore, this compound also displayed activity at the $\mathrm{D}_{2} \mathrm{R}$, and as such, may represent a novel allosteric scaffold for this receptor.

To date, very few ligands have been characterised as allosteric modulators of $\mathrm{D}_{2}$-like dopamine receptors including the drug-like ligand SB269652 (Figure 1); which acts to negatively modulate dopamine affinity at the $D_{2} R$ and $D_{3} R .{ }^{10-12}$ Structure-based virtual ligand screening (VLS) provides an attractive path for efficient discovery of allosteric ligands. However, it is important to validate this approach through optimisation of 
initial VLS hits. ${ }^{13,14}$ Currently, there is no structure-activity relationship (SAR) data associated with 1, but there is much scope for further structural interrogation. We therefore undertook a study to identify novel allosteric modulators for the $\mathrm{D}_{2} \mathrm{R}$, based on the structure of $\mathbf{1}$. Through modifications to the scaffold of $\mathbf{1}$, we aimed to identify key molecular features responsible for its allosteric action at the $\mathrm{D}_{2} \mathrm{R}$ (Figure 2). We applied analytical pharmacological methods to allow us to supplement this SAR study with measures of allosteric ligand action to include not only allosteric ligand affinity $\left(K_{\mathrm{B}}\right)$, but also the magnitude of modulatory effects upon dopamine affinity $(\alpha)$ and efficacy $(\beta)$. Such an approach may be useful as a starting point to understand the relationship between allosteric ligand behavior and the in vivo efficacy of such modulators. Indeed, to explore negative allosteric modulation as an approach to treat the positive symptoms of schizophrenia it would be advantageous to have a set of $\mathrm{D}_{2} \mathrm{R}$ NAMs that display a range of different allosteric behaviors from modulation of dopamine affinity through to modulation of dopamine efficacy. Herein, we report the design, synthesis, and detailed pharmacological characterisation of $\mathbf{1}$, together with a library of structural analogues. We provide evidence that $\mathbf{1}$ does indeed act via an allosteric site at the $\mathrm{D}_{2} \mathrm{R}$ and reveal that $\mathbf{1}$ exerts distinct pharmacology to that of SB269652, whereby it acts to modulate dopamine efficacy rather than dopamine affinity. Promising low molecular weight candidates with marketedly improved lipophilic ligand efficiencies (LLE) have been identified, and thus represent an attractive starting point for the development of novel $\mathrm{D}_{2} \mathrm{R}$ NAMs that modulate dopamine efficacy, affinity or both.

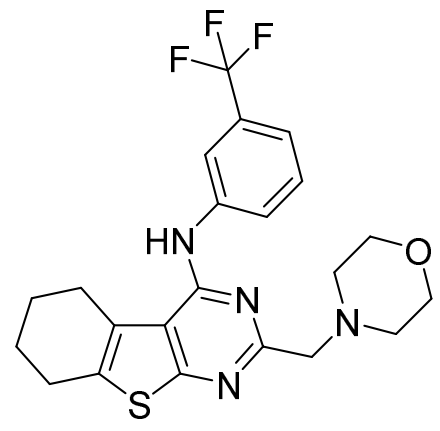

1

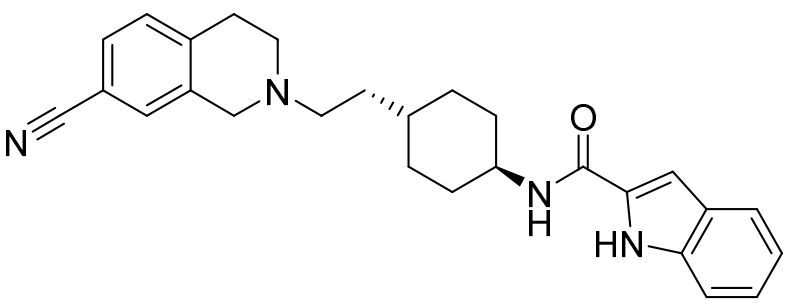

SB269652 (2)

Figure 1. Compound 1 (above left) (2-(morpholinomethyl)- $N$-(3-(trifluoromethyl)phenyl)-5,6,7,8tetrahydrobenzo[4,5]thieno[2,3-d]pyrimidin-4-amine) (above left) was identified from a virtual ligand screen targeting orthosteric and allosteric pockets of the dopamine $\mathrm{D}_{2}$-like receptors. SB269652 (2) (above right), is the first drug-like NAM of the dopamine $\mathrm{D}_{2}$ receptor. ${ }^{10}$ 


\section{- RESULTS \& DISCUSSION}

Chemistry. In order to validate the pharmacological activity of lead compound $\mathbf{1}$, it was resynthesised using a five step chemical synthesis outlined in Scheme $1 .{ }^{15}$ Gewald chemistry permitted the one-pot assembly of ethyl 2-amino-4,5,6,7-tetrahydrobenzo[b]thiophene-3-carboxylate $\quad \mathbf{5}$ via commercially available cyclohexanone 2 , ethyl cyanoacetate 3 and sulfur, catalysed by diethylamine in absolute ethanol at $60{ }^{\circ} \mathrm{C}$ to afford the fused thiophene $\mathbf{5}$ as brilliant orange needles. ${ }^{15}$ Next, $\mathbf{5}$ was subjected to an acid catalysed intermolecular cyclisation in 1,4-dioxane at room temperature using chloroacetonitrile and hydrogen chloride gas generated in situ (Kipp's apparatus) to yield the 2-chloro substituted thieno[2,3-d]pyrimidin-4(3H)-one core scaffold $\mathbf{6}$ as a precipitated white solid. ${ }^{16}$ Subsequent $N$-alkylation with morpholine was achieved in DMF at $100{ }^{\circ} \mathrm{C}$ folowed by cooling to room temperature to precipitate the desired product 7 . Activation of the pyrimidinone was accomplished with an adapted procedure using phosphorus oxychloride $\left(\mathrm{POCl}_{3}\right)$ and catalytic DMF in toluene to give the corresponding chloropyrimidine $\mathbf{8}$ as a brown oil in good yield. Finally, 8 was subjected to microwave assisted nucleophilic aromatic substitution with 3-(trifluoromethyl)aniline in $i-\mathrm{PrOH}$ to afford the target compound $\mathbf{1}$, following chromatography and recrystallisation from chloroform.

\section{Scheme 1. Chemical Synthesis of $1^{a}$}
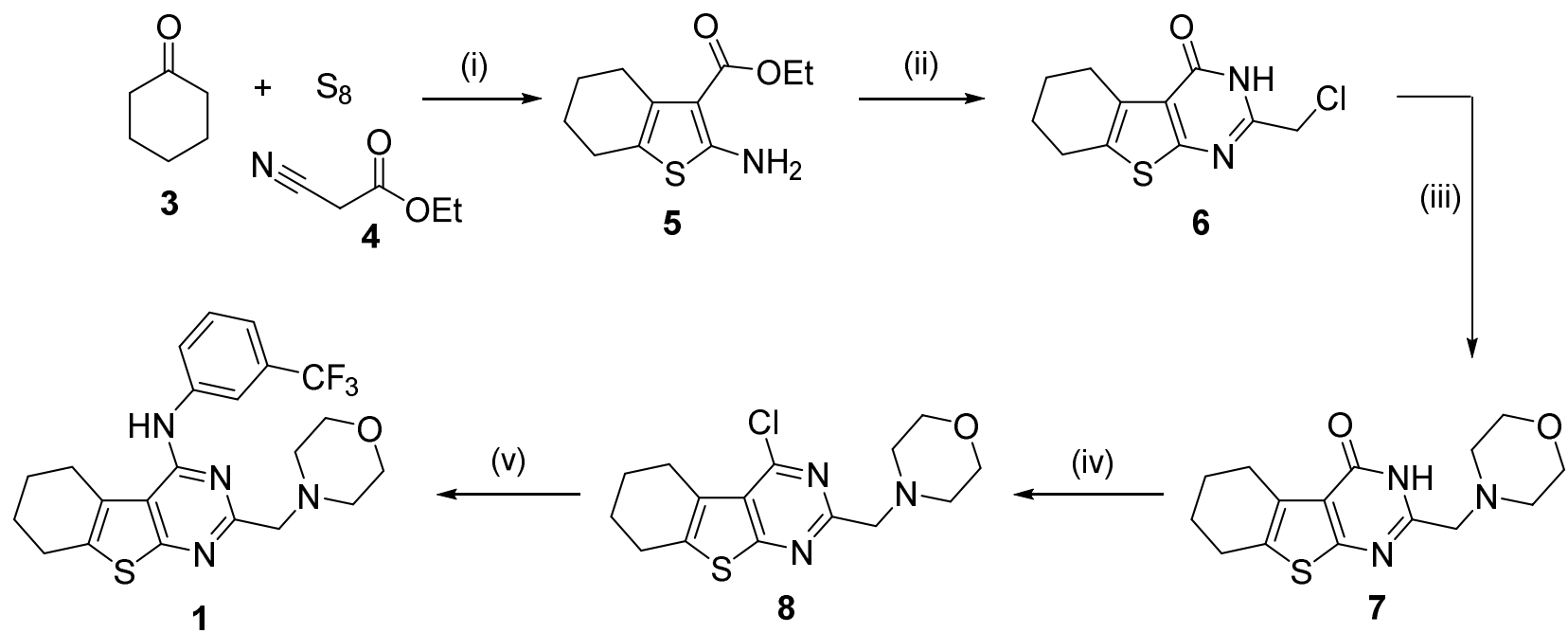

${ }^{a}$ Reagents and conditions: (i) morpholine, $0-45^{\circ} \mathrm{C}, 80 \%$; (ii) chloroacetonitrile, 1,4-dioxane, $\mathrm{HCl}_{(\mathrm{g})}$ (Kipp's apparatus), $50{ }^{\circ} \mathrm{C}, 2 \mathrm{~h}, 85 \%$; (iii) $\mathrm{DMF}$, morpholine, $\mathrm{Et}_{3} \mathrm{~N}, 100{ }^{\circ} \mathrm{C}, 2 \mathrm{~h}, 80 \%$; (iv) $\mathrm{POCl}_{3}$, toluene, $100{ }^{\circ} \mathrm{C}, 4 \mathrm{~h}$, 75\%; (v) $i$-PrOH, $m$-trifluoromethylaniline, MWI, 2 h, 70\%. 
Single Modifications to Fused Cyclohexane Moiety, 2-, and 4-Positions of 1 . In addition to 1, we generated a focused library of thieno[2,3-d]pyrimidine analogues bearing single structural modifications to examine the effect on functional binding affinity and allosteric pharmacology of the scaffold (Figure 2). This included modifying the fused ring system - initially observing the effect of differing ring size (fused cyclopentane 14a, cycloheptane 14b and cyclooctane 14c) (Schemes 2 and 3), as well as the effects of removing substitution at the 5- and 6-position of the thienopyrimidine 14j. Moreover, we explored functionalisation of both the 5- and 6-positions with various substituents (6-phenyl, 14d; 5-phenyl, 14e; 6-benzyl, 14f; 5-cyclohexyl, 14g; 5,6dimethyl, 14h; 6-cyclohexyl, 14i) (Scheme 3) to provide an understanding of the chemical space surrounding this moiety for further future elaboration. We investigated the effect of removing the $\mathrm{CF}_{3}$ substituent on the aryl ring 16a, and the influence of incorporating additional substituents with different electronic effects (3-F, 16b; 3- $\left.\mathrm{OCH}_{3}, \mathbf{1 6 c} ; 3-\mathrm{OH}, 17\right)$ (Scheme 4). In addition to this, we explored the role of the secondary aliphatic amine bridging the substituted aryl moiety in $\mathbf{1}$ through the synthesis of two analogues bearing $N$-methylamino (18) and $N, N$-diethylamino (19) substituents (Scheme 4). The role of this secondary amine was further probed through the removal of its hydrogen-bond donor property via isosteric replacement with an ether linkage (20) (Scheme 4). This would permit the assessment and influence of hydrogen bond donor removal and any subsequent functional effects on the allosteric pharmacology of $\mathbf{1}$. The $N$-methylamino derivative (18) would test the importance of aromaticity whilst still maintaining hydrogen-bond characteristics of $\mathbf{1}$, while the $N, N$ diethylamino analogue (19) investigates the impact of removing aromaticity and hydrogen-bond donor properties at the 4-position. Additionally, the ether derivative (20) assesses the importance of removing hydrogen-bond donor properties while maintaining aromaticity. We also focused on the 2-position of $\mathbf{1}$, where we sought to evaluate the impact of removing the 2-morpholinomethyl moiety entirely (23a, Scheme 5), subsequently conferring no substitution at the 2-position of the thienopyrimidine. In addition to this, we investigated isosteric replacement of the morpholino $\mathrm{O}$ for $\mathrm{CH}_{2}$ to afford the piperidine analog $\mathbf{2 6}$ (Scheme 6), as well as a similar replacement of $\mathrm{N}$ for $\mathrm{CH}$ to furnish the tetrahydopyran analog $33 \mathbf{a}$ (Scheme 7). Moreover, we investigated the effects of increasing the methylene linker length bearing morpholine (ethylene, 39a; propylene, 39b; butylene, 39c) (Scheme 8). 


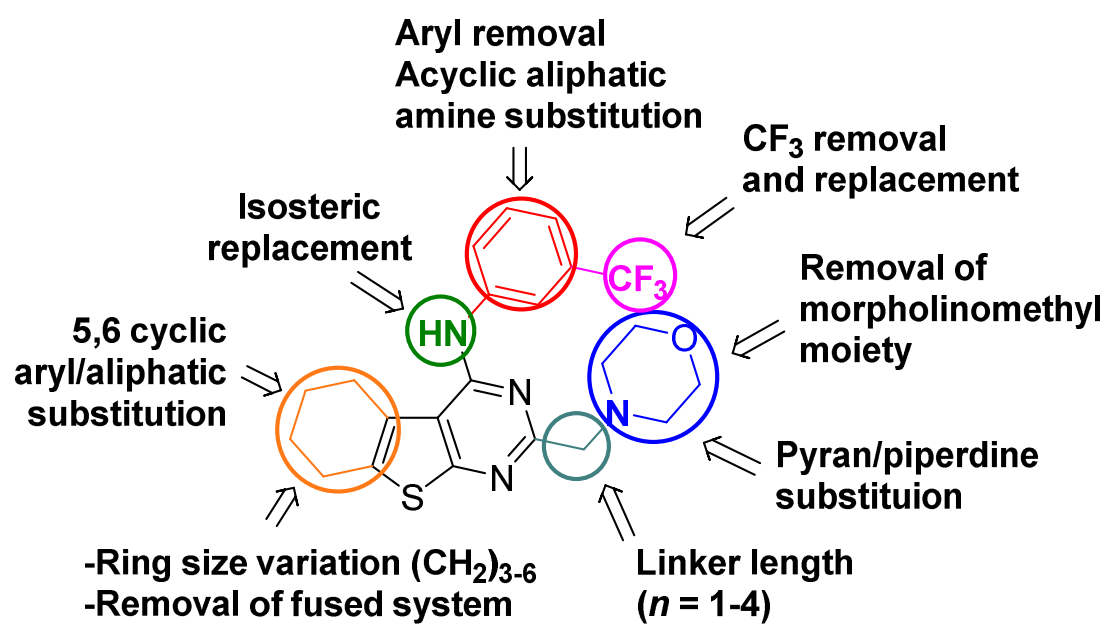

Figure 2. Areas of structural modification of 1 conducted during intial SAR investigation.

Hybrid Modification of $\mathbf{1}$. Several additional compounds were synthesised to further investigate the effects of the aforementioned structural modifications. These modifications included deletion of the fused cyclohexane system of the tricyclic scaffold, removal of the 2-morpholinomethyl pendant, isosteric replacement through substitution of the morpholine ring for tetrahydropyran, and the incorporation of a 1,4-butylene linker; all bearing the $N, N$-diethylamino functionality in place of the aryl $m-\mathrm{CF}_{3}$ moiety. These subsequent analogues (23b, Scheme 5), (33b, Scheme 7), (40, Scheme 9), (44, Scheme 11) were synthesised as outlined previously by varying the nature of the nucleophile used in the final nucleophilic aromatic substitution. Finally, a further four analogues (43a-b, Scheme 10: 47a-b, Scheme 11), were synthesised to examine the effects of simultaneous deletion/instalment of functionality with respect to maintaining one of either $m-\mathrm{CF}_{3}$-aryl or $N, N$ diethylamino substituents at the 4-position of $\mathbf{1}$.

The thieno[2,3- $d]$ pyrimidine moiety (Figure 2) is prevalent in a variety of reported compounds, thus its synthesis is well established. ${ }^{17-22}$ Rapid access to a series of analogues substituted at the 5- and 6-positions was achieved using the appropriate aldehyde or ketone as a starting material, by means of Gewald-type chemistry (Scheme 2). An alternative method to traditional Gewald chemistry using solvent-free conditions for the preparation of substituted 2-aminothiophene derivatives from respective ketones/aldehydes in the presence of morpholine as catalyst was used to furnish a parallel set of analogues (Scheme 2). ${ }^{23}$ The commercial availability of aldehydes (9d, 9f, 9i) or ketones $(\mathbf{9 a - c}, 9 \mathbf{9}, 9 \mathrm{~g}, 9 \mathbf{9 h})$ and their usefulness in Gewaldtype chemistries or variations thereof permitted easy access to a variety of substituted thienocarboxylate 
precursors 10a-i bearing a primary amine and ethyl ester as functional handles. Ethyl 2-aminothiophene-3carboxylate 10j, was obtained in accordance with an adapted procedure ${ }^{24}$ (Scheme 2 ) using the commercially available mercaptoacetaldehyde dimer, 1,4-dithiane-2,5-diol (9j). This reagent was successfully used to afford $\mathbf{1 0 j}$ as a yellow crystalline solid in good yield.

\section{Scheme 2. Chemical Synthesis of 2-Amino-3-Carbethoxythiophenes ${ }^{a}$}

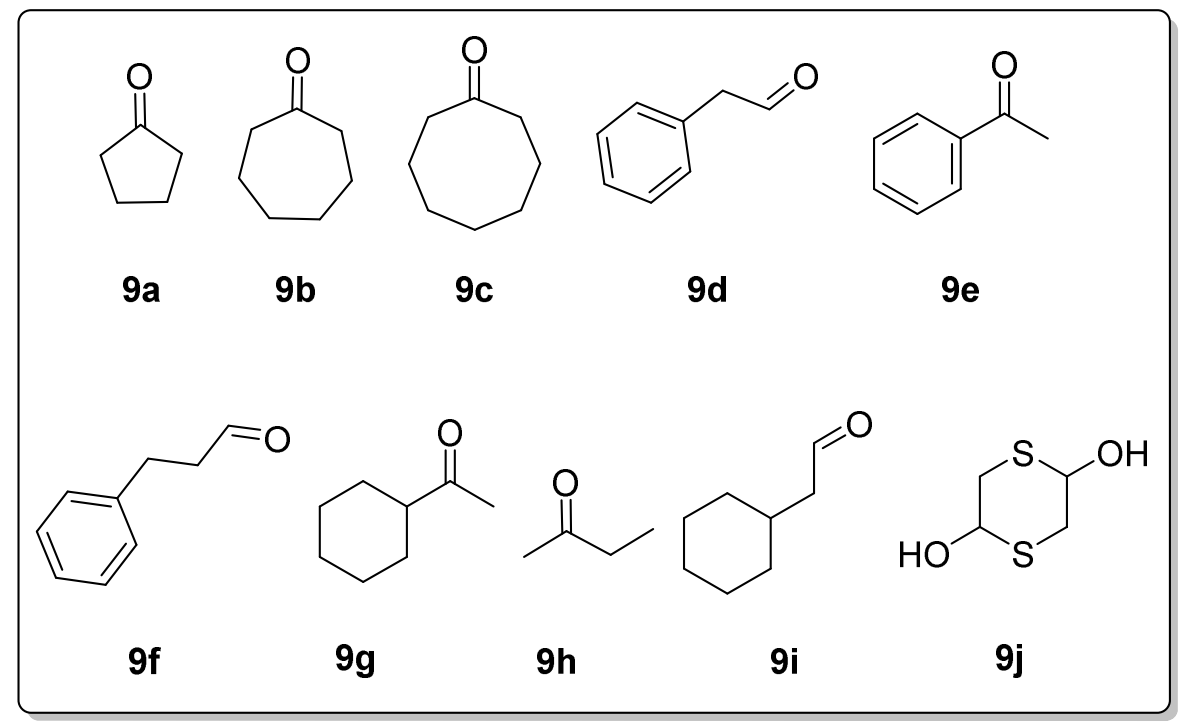<smiles>[R]c1sc(N)c(C(=O)OCC)c1[R]</smiles>

$10 \mathrm{a}-\mathrm{j}$

$$
\begin{aligned}
& \text { a } \mathrm{R}^{1}=\mathrm{R}^{2}=\left(\mathrm{CH}_{2}\right)_{3} \\
& \text { (i) } \quad \mathrm{R}^{1}=\mathrm{R}^{2}=\left(\mathrm{CH}_{2}\right)_{5} \\
& \text { (ii) } \mathrm{R}^{1}=\mathrm{R}^{2}=\left(\mathrm{CH}_{2}\right)_{6} \\
& \text { (ii) } \mathbf{d} \mathrm{R}^{1}=\mathrm{H}, \mathrm{R}^{2}=\text { phenyl } \\
& \text { e } \mathrm{R}^{1}=\text { phenyl, } \mathrm{R}^{2}=\mathrm{H} \\
& \text { f } \mathrm{R}^{1}=\mathrm{H}, \mathrm{R}^{2}=\mathrm{Bn} \\
& \text { g } \mathrm{R}^{1}=\text { cyclohexyl, } \mathrm{R}^{2}=\mathrm{H} \\
& \text { h } \mathrm{R}^{1}=\mathrm{R}^{2}=\mathrm{CH}_{3} \\
& \text { i } \mathrm{R}^{1}=\mathrm{H}, \mathrm{R}^{2}=\text { cyclohexyl } \\
& \text { j } \mathrm{R}^{1}=\mathrm{R}^{2}=\mathrm{H}
\end{aligned}
$$$$
\text { (i) }
$$

${ }^{a}$ Reagents and conditions: (i) sulfur, abs. EtOH, ethyl cyanoacetate, $60{ }^{\circ} \mathrm{C}, 3-4 \mathrm{~h}, 50-80 \%$ (10a-c); (ii) sulfur, morpholine (neat), ethyl cyanoacetate, r.t., $\sim 18 \mathrm{~h}, 45-80 \%$ (10d-i); (iii) Et $3 \mathrm{~N}$, ethyl cyanoacetate, DMF, $45^{\circ} \mathrm{C}$, $0.5 \mathrm{~h}, 55 \%(\mathbf{1 0 j})$.

To allow construction of the 2-chloromethyl-substituted pyrimidine bearing a functional handle for further elaboration, the appropriate thiophenes $\mathbf{1 0 a - j}$ were subjected to an intermolecular cyclisation reaction under acidic conditions in the presence of chloroacetonitrile to afford the desired thieno[2,3- $d]$ pyrimidine core which could be utilised for further derivatisation (Scheme 3). Cyclisation required dry $\mathrm{HCl}$ gas to be generated in situ (Kipps' apparatus) and to be passed through a solution containing the respective nitrile and thiophene, furnishing the corresponding 2-haloalkyl pyrimidinones 11a-j in high yields. ${ }^{16}$ 
Scheme 3. Chemical Synthesis of Analogues of 1 with Modifications to Fused Cyclohexane System ${ }^{a}$<smiles>[R]c1sc(N)c(C(=O)OCC)c1[R]</smiles>

$10 a-j$<smiles>[R]c1sc2nc(CN3CCCCC3)nc(Nc3cccc(C(F)(F)F)c3)c2c1[R]</smiles>

14a-j<smiles>[R]c1sc2nc(CCl)[nH]c(=O)c2c1[R]</smiles>

11a-j<smiles>[R]c1sc2nc(CN3CCOCC3)[nH]c(=O)c2c1[R]</smiles>

$12 a-j$

$N$-Alkylation of morpholine with 11a-j was conducted in DMF and typically proceeded smoothly to provide the corresponding morpholinomethyl analogues 12a-j. Products could often be precipitated with $\mathrm{H}_{2} \mathrm{O}$, washed with an appropriate solvent and/or recrystallised. Carbonyl activation was achieved through the use of $\mathrm{POCl}_{3}$ along with catalytic DMF in toluene to attain clean conversion to the corresponding chloropyrimidines (13aj). Finally, the appropriate chloropyrimidine (13a-j) could be taken up in $i-\mathrm{PrOH}$ and subjected to microwaveassisted nucleophilic aromatic substitution in the presence of the appropriate nucleophile (primary aromatic or secondary acyclic aliphatic amine) and an excess of Hünigs base to furnish target analogues $\mathbf{1 4 a - j}$ in good yields. Initially, DMF was trialed as a potential reaction solvent for nucleophilic aromatic substitution, however produced sub-optimal yields and by-products, and thus was not used further. Compound $\mathbf{1 5}$ was isolated as a reaction by-product during the attempted synthesis of $\mathbf{1 4 f}$, due to the presence of $N, N$ dimethylamine existing as an impurity in DMF, thus it was characterised and tested for its in vitro activity. 
Substituents at the thienopyrimidine 4-position. Compounds 16a-c were similiarly obtained as previously outlined, through the use of various substituted anilines via nucleophilic aromatic substitution with key chloropyrimidine intermediate 8 (Scheme 4). Compound 16c was used to access the phenolic analogue via $O$ demethylation employing boron tribromide in DCM at $0{ }^{\circ} \mathrm{C}$ to afford the corresponding phenol $\mathbf{1 7}$ in good yield. To assess the impact of removing aromaticity from the 4-position, several additional analogues of $\mathbf{1}$ were synthesised (Scheme 4). To do this, key intermediate $\mathbf{8}$ was again subjected to nucleophilic aromatic substitution using an excess of $N$-methyl or $N, N$-diethylamine under basic conditions in $i$-PrOH which furnished the corresponding $N$-methylamino and $N, N$-diethylamino analogues in good yields as light brown oils (18 \& 19, respectively). To advance our understanding of the aniline's role within $\mathbf{1}$, we generated a compound deficient of a hydrogen-bond donor group through isosteric replacement with an ether linkage but still bearing the aryl- $\mathrm{CF}_{3}$ substituent (20, Scheme 4). To achieve this compound $\mathbf{8}$ was subjected to MWI in the presence of 3-(trifluoromethyl)phenol and a 10\% molar equivalent of phase-transfer catalyst tris[2-(2methoxyethoxy)ethyl]amine (TRIDENT). Subsequent chromatographic purification afforded the target etherderivative $\mathbf{2 0}$ as a transparent oil in $72 \%$ yield.

\section{Scheme 4. Synthesis of Analogues Modified at the 4-Position ${ }^{a}$}

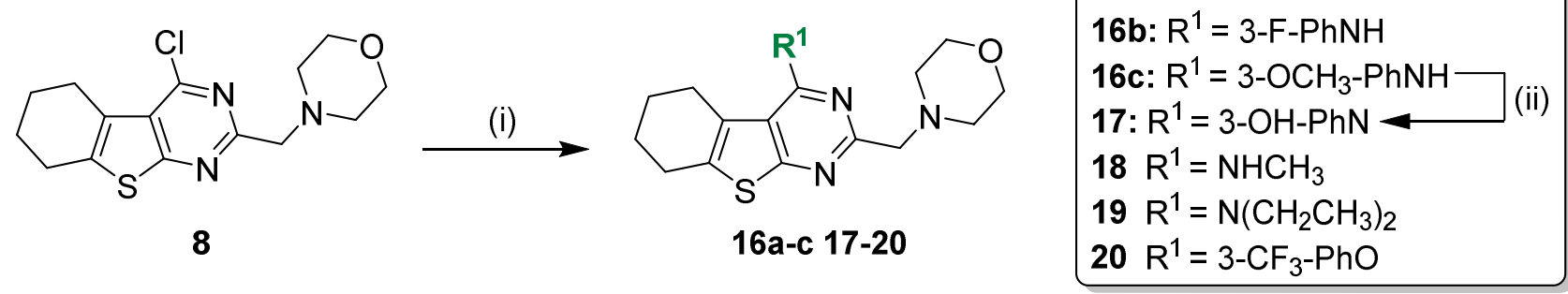

${ }^{a}$ Reagents and conditions: (i) substituted aniline, $i \mathrm{PrOH}, \mathrm{MWI}, 2 \mathrm{~h}, 65-90 \%$ (16a-c); (ii) $\mathrm{BBr}_{3}(1 \mathrm{M}$ in DCM), r.t., overnight, 53\% (17); (iii) $i$-PrOH, methylamine, MWI, $140{ }^{\circ} \mathrm{C}, 2.5 \mathrm{~h}, 85 \%(\mathbf{1 8})$; $i$-PrOH, $N, N$ diethylamine, MWI, $140{ }^{\circ} \mathrm{C}, 3$ h, $91 \%$ (19); $i$-PrOH, 3-(trifloromethyl)phenol, TRIDENT (cat), MWI, 6 h, $72 \%$ (20).

Substituents at the thienopyrimidine 2-position. To assess the effects of removing the 2morpholinomethyl moiety (Scheme 5), 4,5,6,7-tetrahydrobenzothiophene 5 was refluxed for several hours in 
neat formamide to construct the corresponding pyrimidinone 21. This compound was similarly converted to 4-chloro analogue 22, followed by nucleophilic aromatic substitution with 3-(trifluoromethyl)aniline to yield compound 23a (Scheme 5). To further assess the effect of introducing an $N, N$-diethylamino substituent at the 4-position of 1, we synthesised an additional analogue that incorporated this amine in conjunction with removal of the 2-morpholinomethyl substituent (23b, Scheme 5). This compound was accessed using key intermediate 22 via nucleophilic aromatic substitution thereby permitting us to further probe the effect of incorporating an aliphatic 4-substituent but still bearing similar hydrogen-bonding capabilities.

\section{Scheme 5. Chemical Synthesis of Analogues of 1 devoid of Morpholinomethyl Moiety ${ }^{a}$}

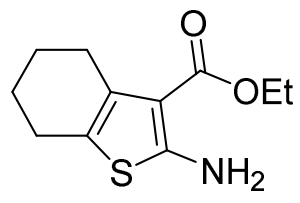

5

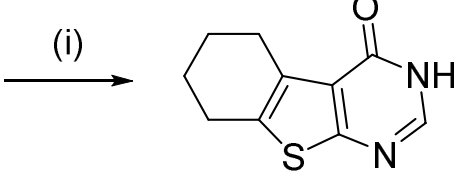

21

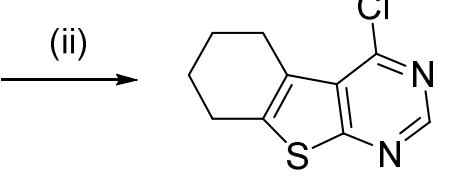

22

$$
\begin{aligned}
23 \text { a R } & =3-\mathrm{CF}_{3}-\mathrm{PhNH} \\
\text { b R }{ }^{1} & =\mathrm{N}\left(\mathrm{CH}_{2} \mathrm{CH}_{3}\right)_{2}
\end{aligned}
$$

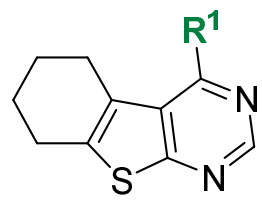

23a-b

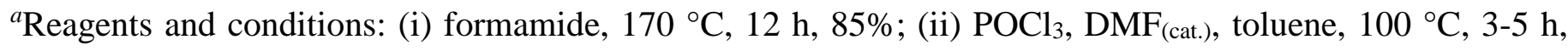
90\%; (iii) $i$-PrOH, $m$-CF - $_{3}$-aniline, DIPEA, MWI, 2 h, 75\% (23a); (iv) $i$-PrOH, $\mathrm{Et}_{2} \mathrm{NH}, \mathrm{DIPEA}, \mathrm{MWI}, 2 \mathrm{~h}$, $90 \%$ (23b).

Next, we focused on the morpholine moiety to probe the effect on the allosteric pharmacology of $\mathbf{1}$ by replacing the $\mathrm{O}$ or $\mathrm{N}$ heteroatoms with a methylene or methine group to give piperidine analogue, $\mathbf{2 6}$ and tetrahydropyran analogue, 33a, respectively. Compound 26 (Scheme 6) was accessed via the $N$-alkylation of piperidine with key intermediate 6, again followed by chlorination (25) and substitution to afford $\mathbf{2 6}$ in good yield. Compound 33a (Scheme 7) was furnished via a multi-step synthesis that initially involved activation of diethyl cyanomethylphosphonate $\mathbf{2 8}$ with $\mathrm{NaH}$, followed by drop-wise addition of tetrahydro- $4 H$-pyran-4-one 27 in diethyl ether. Vacuum distillation and recrystallisation from petroleum-ether afforded the corresponding nitrile 29 as a transparent crystalline solid in moderate yield. Catalytic hydrogenation employing $\mathrm{Pd} / \mathrm{C}$ as catalyst in EtOAc and $\mathrm{AcOH}$ under atmospheric pressure gave the corresponding saturated nitrile $\mathbf{3 0}$ as a 
transparent oil in high purity. Intermolecular cyclisation of thiophene $\mathbf{5}$ with $\mathbf{3 0}$ proceeded in 1,4-dioxane under standard acidic conditions (Kipp's apparatus) to afford the thienopyrimidinone 31, though requiring reflux temperatures to achieve full conversion. Subsequent DMF-catalysed $\mathrm{POCl}_{3}$ activation in toluene provided the chloropyrimidine $\mathbf{3 2}$, followed by nucleophilic aromatic substitution in $i$-PrOH to afford the target tetrahydropyran 33a as a white foam in moderate yield. To better assess the effects of $N, N$-diethylamino substitution of the 4-position in combination with the tetrahydropyran functionality, one additional analogue was synthesised (33b). This compound was readily accessed by reacting the appropriate starting material 32 under standard conditions to afford the target as a light gold oil in good yield (Scheme 7).

\section{Scheme 6. Chemical Synthesis of Piperidine Analogue ${ }^{a}$}<smiles>O=c1[nH]c(CCl)nc2sc3c(c12)CCCC3</smiles>

6<smiles>FC(F)(F)c1cccc(Nc2nc(CN3CCCCC3)nc3sc4c(c23)CCCC4)c1</smiles>

26<smiles>C#CC1CCCc2c1sc1nc(CN3CCCCC3)[nH]c(=O)c21</smiles>

24

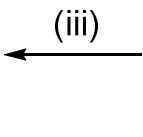<smiles>Clc1nc(CN2CCCCC2)nc2sc3c(c12)CCCC3</smiles>

25

${ }^{a}$ Reagents and conditions: (i) piperidine, $\mathrm{Et}_{3} \mathrm{~N}, 100{ }^{\circ} \mathrm{C}, 2 \mathrm{~h}, 71 \%$; (ii) toluene, $100{ }^{\circ} \mathrm{C} 4 \mathrm{~h}, 46 \%$; (iii) $i$-PrOH, m-trifluoromethylaniline, MWI, 2 h, 70\%. 
Scheme 7. Chemical Synthesis of Tetrahydro-2H-pyran-4-yl Analogues of $\mathbf{1}^{a}$
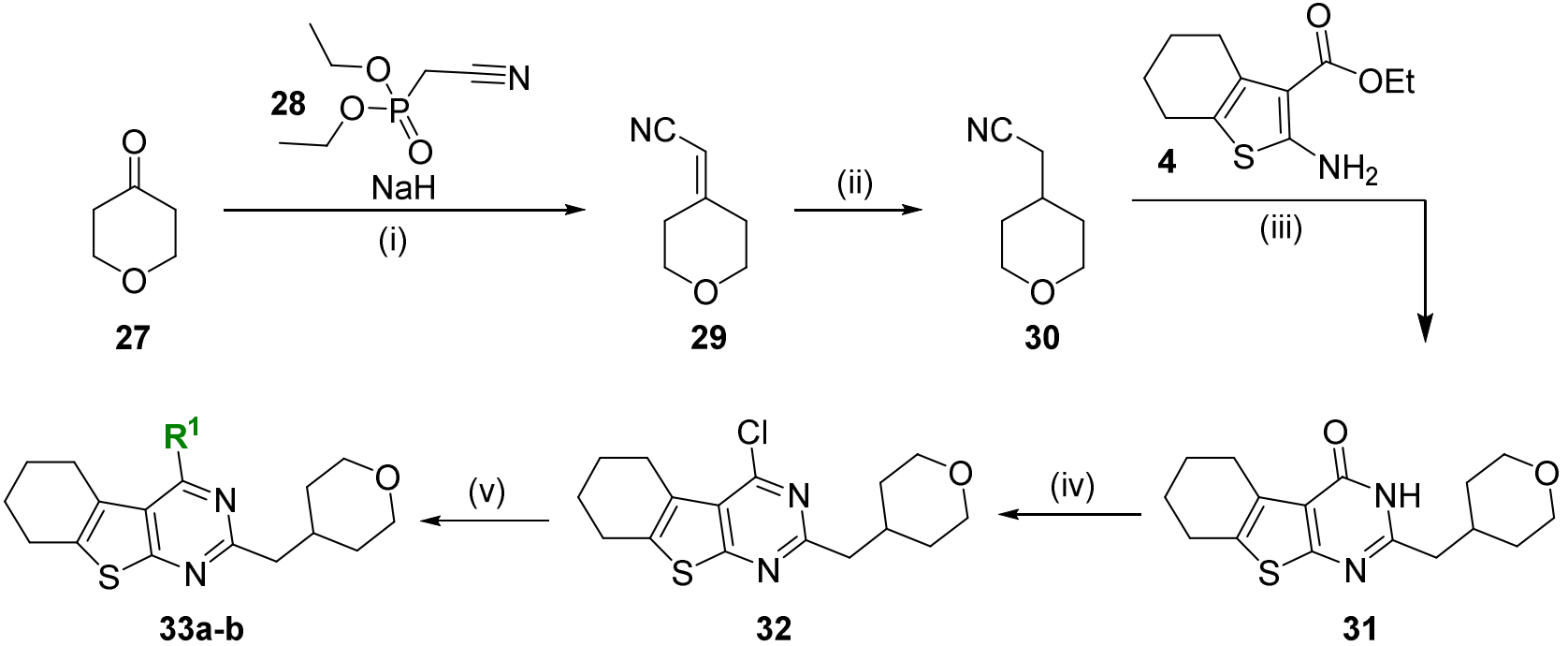

33a $\mathrm{R}^{1}=3-\mathrm{CF}_{3}-\mathrm{PhNH}$

33b R ${ }^{1}=\mathrm{N}\left(\mathrm{CH}_{2} \mathrm{CH}_{3}\right)$

${ }^{a}$ Reagents and conditions: (i) $\mathrm{Et}_{2} \mathrm{O}, 0{ }^{\circ} \mathrm{C}$ - r.t. 24 h, 39\%; (ii) $10 \% \mathrm{Pd} / \mathrm{C}$, EtOAc, $\mathrm{AcOH}, 1$ atm, r.t. 5 h, 100\%; (iii) 1,4-dioxane, $\mathrm{HCl}_{(\mathrm{g})}$, r.t. - reflux, $13 \mathrm{~h}, 93 \%$; (iv) toluene, $\mathrm{POCl}_{3}, \mathrm{DMF}_{\text {(cat.), }} 100{ }^{\circ} \mathrm{C}, 4 \mathrm{~h}, 24 \%$; (v) amine, $i$-PrOH, MWI $120^{\circ} \mathrm{C}, 3 \mathrm{~h}, 48 \%$ (33a); (vi) $i$-PrOH, Et $2 \mathrm{NH}, \mathrm{MWI}, 120^{\circ} \mathrm{C}, 2 \mathrm{~h}, 85 \%$ (33b).

Chain-extension of the 2-substituent linker of $\mathbf{1}$. To investigate the effects of increasing the methylene linker length on the allosteric pharmacology of $\mathbf{1}$, we generated a series of analogues of differing methylene chain length (2-4) bridging the morpholine substituent to the pyrimidine core (Scheme 8). Commercially available primary chloroalkyl nitriles: 3-chloropropionitrile 34a, 4-chlorobutanenitrile $\mathbf{3 4 b}$ and 5-chloropentanenitrile $\mathbf{3 4 c}$, were reacted in the presence of thiophene $\mathbf{5}$ under standard acidic conditions in order to furnish the corresponding chain-extended pyrimidinones (36a-c). These nitriles were substantially less reactive than chloroacetonitrile, and thus required reflux temperatures to complete the conversion of the amidinium species formed in situ to the corresponding 2-chloro-pyrimidinone.

Using standard conditions, alkylation of morpholine with the appropriate chain extended chloro-pyrimidinone was attempted to generate the corresponding morpholinoethyl, morpholinopropyl, and morpholinobutyl substituted intermediates 37a-c. This methodology successfully afforded the morpholinoethyl pyrimidinone 37a in good yield as a yellow crystalline solid (Scheme 8), however pyrimidinone derivatives bearing the longer chloroalkyl chains were suspected to be eliminating under basic conditions. ${ }^{1} \mathrm{H}$ NMR analysis provided 
confirmation of favoured intramolecular cyclisation under both ambient and reflux conditions, generating two tetracyclic regioisomers in a 1:1 ratio. ${ }^{25}$ In light of this, additional efforts focused on construction of the $N$ substituted nitrile moiety first (Scheme 8). This was accomplished by stirring the appropriate nitrile (34a-c) with an excess of morpholine in refluxing toluene for several hours to furnish the corresponding $N$-morpholino nitriles (35a-c) in good yields as transparent oils. These intermediates were reacted with $\mathbf{5}$ under acidic conditions to afford the target morpholinopropyl and morpholinobutyl pyrimidinones in good yields (37b-c) followed by chlorination (38a-c) and subsequent nucleophilic aromatic substitution to furnish the final chain extended analogues 39a-c.

\section{Scheme 8. Synthesis of Morpholino-Substituted Nitriles and Corresponding Alkyl Chain-Extended}

\section{Analogues of $1^{a}$}

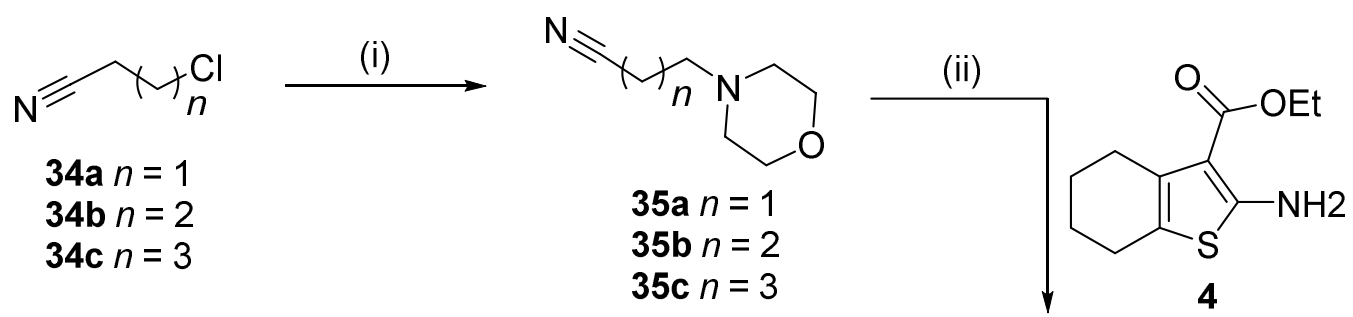<smiles>[R]c1sc2c(c1C(=O)OCC)CCCC2</smiles><smiles>C[C@@H]1CCCc2c(sc3nc(CCCl)[nH]c(=O)c23)C1</smiles>

$$
\begin{aligned}
& 36 \mathbf{a} n=1 \\
& 36 \mathbf{b} n=2 \\
& 36 \mathbf{c} n=3
\end{aligned}
$$$$
\text { (vi) or (vii) }
$$<smiles>ClC1NC(CCCN2CCOCC2)=Nc2sc3c(c21)CCCC3</smiles>

$$
\begin{array}{ll}
39 \mathbf{a} n=1 & 38 \mathbf{a} n=1 \\
39 \mathbf{b} n=2 & 38 \mathbf{b} n=2 \\
39 \mathbf{c} n=3 & 38 \mathbf{c} n=3
\end{array}
$$

${ }^{a}$ Reagents and conditions: (i) morpholine, toluene, reflux, 7 h, 45-65\% (35a-c); (ii) 1,4-dioxane, nitrile, $\mathrm{HCl}$ (g), r.t. 12 h, reflux 4 h, 57-80\% (37b-c); (iii) 34a-c, 1,4-dioxane, $\mathrm{HCl}_{(\mathrm{g})}$, r.t. 12 h - reflux 3 h, 60-83\% (36a- 


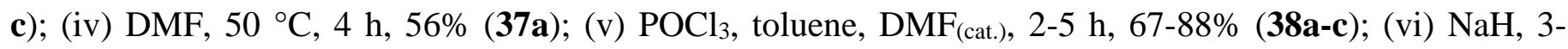
(trifluoromethyl)aniline, DMF, $100{ }^{\circ} \mathrm{C}, 6$ h, 27\% (39a); (vii) $i$-PrOH, MWI, 2-4 h, 56-59\% (39b-c).

Hybrid Functionalisation of 2- and 4-positions of 1 . The subsequent pharmacological effects of incorporating extended morpholinoalkyl substituents into analogues of 1 (39a-c) conveyed interesting changes in the functional properties of this scaffold. The 1,4-butylene linker was of particular interest. Thus, compound 40 was synthesised using intermediate 38c (Scheme 9) via nucleophilic aromatic substitution to enhance our understanding of the SAR surrounding the 4-position of 1 with respect to $N, N$-dimethylamino substitution. In addition to further investigate the 1,4-butylene linker, removal of the fused functionality within $\mathbf{1}(\mathbf{1 4} \mathbf{j})$ resulted in a loss of not only binding affinity, but rendered this analogue functionally inactive. To this end, we sought to investigate the effect of removing the fused cyclohexane system whilst maintaining the morpholinobutyl functionality in conjunction with one of either 3(trifluoromethyl)anilino or $N, N$-diethylamino substitutents at the 4-position (Scheme 10). These two additional analogues were accessed by reacting the appropriate unsubstituted thiophene $\mathbf{1 0 j}$ with $\mathbf{3 5 c}$ under acidic conditions to provide cyclised product $\mathbf{4 1}$, followed by chlorination $\mathbf{4 2}$ and nucleophilic aromatic subsitution employing conditions as outlined previously to furnish 43a-b in good yields (Scheme 10).

Scheme 9. Synthesis of $N, N$-Diethylamino Analogue Bearing Morpholinobutyl Substitutent \& Fused Cyclohexane Moiety ${ }^{a}$

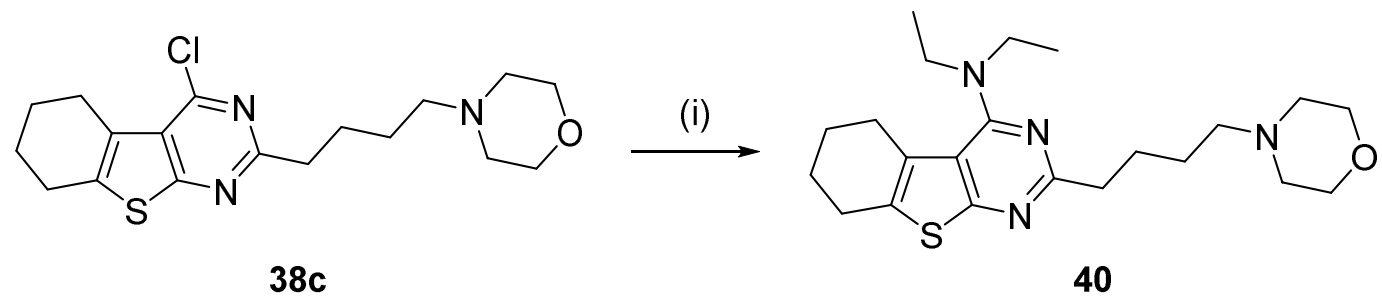

${ }^{a}$ Reagents and conditions: (i) $i$-PrOH, Et $2 \mathrm{NH}, \mathrm{MWI}, 120{ }^{\circ} \mathrm{C}, 3 \mathrm{~h}, 85 \%$ 
Scheme 10. Further Analogues of 1 Bearing the Morpholinobutyl Substituent ${ }^{a}$<smiles>CCOC(=O)c1ccsc1N</smiles>

10j<smiles>[R]c1nc(CCCCN2CCOCC2)nc2sccc12</smiles>

43a $\mathrm{R}^{1}=3-\mathrm{CF}_{3}-\mathrm{PhNH}$ 43b R $\mathrm{R}^{1}=\mathrm{N}\left(\mathrm{CH}_{2} \mathrm{CH}_{3}\right)_{2}$<smiles>O=c1[nH]c(CCCCN2CCOCC2)nc2sccc12</smiles>

41<smiles>Clc1nc(CCCCN2CCOCC2)nc2sccc12</smiles>

42

${ }^{a}$ Reagents and conditions: (i) 1,4-dioxane, $\mathrm{HCl}_{(\mathrm{g})}$, r.t overnight, reflux 3-6 h, 57-65\%; (ii) toluene, $\mathrm{POCl}_{3}$, $\mathrm{DMF}_{\text {(cat.), }} 3 \mathrm{~h}, 60-88 \%$ (iii) $i$-PrOH, $\mathrm{Et}_{2} \mathrm{NH}, \mathrm{MWI}, 120{ }^{\circ} \mathrm{C}, 1.5 \mathrm{~h}, 80 \%$ (43a); $i$-PrOH, Et $2 \mathrm{NH}, \mathrm{MWI}, 120{ }^{\circ} \mathrm{C}$, 4 h, $90 \%$ (43b).

In addition to this, we wanted to observe the effects of $N, N$-diethylamino substitution of $\mathbf{1 4} \mathbf{j}$ as a direct

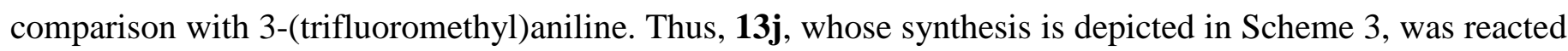
with $\mathrm{N}, \mathrm{N}$-diethylamine under microwave irradiation to afford $\mathbf{4 4}$ in good yield (Scheme 11). Moreover, we wanted to observe the effect of aromatic and aliphatic substituents at the 4-position of $\mathbf{1}$ in conjunction with concurrent removal of the fused cyclohexane and morpholinomethyl moieties. Removal of said functionalities on the structure of $\mathbf{1}$ effectively results in a low molecular weight fragment-like core. These compounds were readily accessed using chemistry as outlined previously (Scheme 11) to furnish the target analogues $\mathbf{4 7 a - b}$ in high yields. 
Scheme 11. Further Thieno[2,3-d]pyrimidin-4-amine Analogues of $1^{a}$

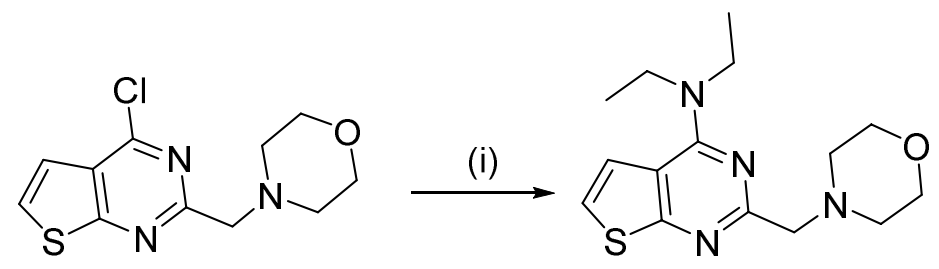

13j

44<smiles>CCOC(=O)c1ccsc1N</smiles>

10j (ii)<smiles>O=c1[nH]cnc2sccc12</smiles>

45<smiles></smiles><smiles>Clc1ncnc2sccc12</smiles>

46
47 a $\mathrm{R}^{1}=3-\mathrm{CF}_{3}-\mathrm{PhNH}$ b $\mathrm{R}^{1}=\mathrm{N}\left(\mathrm{CH}_{2} \mathrm{CH}_{3}\right)_{2}$<smiles>[R]c1ncnc2sccc12</smiles>

$47 a-b$

${ }^{a}$ Reagents and conditions: (i) $\mathrm{Et}_{2} \mathrm{NH}$, DIPEA, $i$-PrOH, MWI, $120{ }^{\circ} \mathrm{C} 1.5 \mathrm{~h}, 94 \%$ (44); (ii) formamide, $170{ }^{\circ} \mathrm{C}$, $6 \mathrm{~h}, 76 \%$; (iii) toluene, $\mathrm{POCl}_{3}, \mathrm{DMF}_{\text {(cat.) }}, 3 \mathrm{~h}, 88 \%$; (iv) $m$-CF $\mathrm{CF}_{3}$-aniline, DIPEA, $i$-PrOH, MWI, $120{ }^{\circ} \mathrm{C} 2.5 \mathrm{~h}$, $80 \%$ (47a); $\mathrm{Et}_{2} \mathrm{NH}$, DIPEA, $i$-PrOH, MWI, $120^{\circ} \mathrm{C} 1.5$ h, $90 \%$ (47b).

Pharmacology. Confirmation of an allosteric mode of action for 1 at the $D_{2} R$. Our previous study predicted that 1 can adopt an allosteric pose within the $\mathrm{D}_{3} \mathrm{R}^{\mathrm{APO}}$ model and revealed that this compound also displayed activity at the $\mathrm{D}_{2} \mathrm{R}$, our primary target of interest. ${ }^{8}$ Prior to initiating an investigation into $\mathbf{1}$, we wanted to confirm its activity at the $\mathrm{D}_{2} \mathrm{R}$, and determine if it displays competitive or allosteric pharmacology. Equilibrium radioligand binding experiments were performed on 1 to monitor its effect upon orthosteric ligand ( $\left[{ }^{3} \mathrm{H}\right]$ raclopride) binding in membranes prepared from FlpIn CHO cells stably expressing the long isoform of the human $\mathrm{D}_{2} \mathrm{R}\left(\mathrm{hD_{2L }} \mathrm{R}\right){ }^{26}$ This assay may also provide indication of an allosteric versus competitive mode of action. If the compound displays incomplete or partial displacement of the radioligand this is consistent with the saturable effect of an allosteric modulator whereby the degree of negative cooperativity with the radioligand detemines the level of radioligand displacement. In cases where one observes only partial 
displacement, data may be fit using an allosteric ternary complex model to derive a value of affinity, denoted as $K_{\mathrm{B}}$, and cooperativity with $\left[{ }^{3} \mathrm{H}\right]$ raclopride $(\alpha) .{ }^{27}$ However, in our assay, $\mathbf{1}$ was able to completely displace $\left[{ }^{3} \mathrm{H}\right]$ raclopride. Therefore, this assay did not allow us to discriminate between high negative cooperativity with the $\left[{ }^{3} \mathrm{H}\right]$ raclopride or competition for the orthosteric binding site (Table 1). Thus, to determine evidence of an allosteric mode of action for this ligand, we extended our evaluation to measurements of $\left[{ }^{3} \mathrm{H}\right]$ raclopride dissociation from the $\mathrm{D}_{2} \mathrm{R}$ (Figure $3 \mathrm{~A}$ ). Dissociation of the radioligand was measured following addition of a high concentration of cold orthosteric ligand $\left(10 \mu \mathrm{M}\right.$ haloperidol) to prevent $\left[{ }^{3} \mathrm{H}\right]$ raclopride rebinding in the absence or presence of $\mathbf{1}$. In the presence of $100 \mu \mathrm{M}$ of $\mathbf{1}$, the dissociation rate of $\left[{ }^{3} \mathrm{H}\right.$ ]raclopride from the $\mathrm{D}_{2} \mathrm{R}$ significantly increased, (Table 2 and Figure $3 \mathrm{~A}$ ) consistent with $\mathbf{1}$ binding to an allosteric site within the $\mathrm{D}_{2} \mathrm{R}^{28}$ Our pharmacological analysis using the above radioligand binding assay did not provide information regarding the modulatory effect of $\mathbf{1}$ upon the neurotransmitter dopamine. Therefore, we tested $\mathbf{1}$ in an assay measuring inhibition of forskolin-stimulated cyclic adenosine monophosphate (cAMP) accumulation through activation of the $\mathrm{hD}_{2 \mathrm{~L}} \mathrm{R}$ stably expressed in FlpIn CHO cells using a BRET biosensor. ${ }^{29}$ The concentrationdependent response of dopamine was measured in the presence of increasing concentrations of $\mathbf{1}$ and $10 \mu \mathrm{M}$ forskolin. Application of an operational model of allosterism to the concentration-response data yielded an estimate of affinity of $\mathbf{1}$ for the unoccupied receptor $\left(K_{\mathrm{B}}\right)$, and its cooperativity with dopamine where $\alpha$ is cooperativity exerted upon dopamine binding, and $\beta$ denotes modulation of dopamine efficacy. ${ }^{30}$ These data are reported in Table 4 and are presented as logarithms to base 10 to allow statistical comparison. ${ }^{31}$ Values of $\alpha$ or $\beta<1$ signify negative cooperativity with dopamine. The lead compound $\mathbf{1}$ acted as a negative allosteric modulator at the $\mathrm{D}_{2} \mathrm{R}$, with low $\mu \mathrm{M}$ functional affinity $\left(K_{\mathrm{B}}=3.9 \mu \mathrm{M}\right)$. The depression in the maximal response upon the dopamine dose-response curve caused by increasing concentrations of $\mathbf{1}$ is characteristic of the action of a NAM of agonist efficacy (Figure 3B). In order to fit these data, the cooperativity of $\mathbf{1}$ with dopamine affinity $(\alpha)$ was constrained to be neutral, allowing us to estimate a value of modulatory action upon dopamine efficacy $(\beta=0.28)$ that equates to a maximal 3-fold decrease (Figure 3B, Table 4). This action is different to the action of the competitive antagonist haloperidol at the $\mathrm{D}_{2} \mathrm{R}$ that acts to cause a dextral shift in the dopamine dose-response curve with no affect upon the maximal effect of dopamine (Figure 3C). Thus, by using complementary pharmacological approaches including equilibrium and dissociation kinetic binding analyses, 
together with experiments measuring $\mathrm{D}_{2}$ receptor function, we have confirmed that $\mathbf{1}$ acts through a noncompetitive mechanism to modulate the activity of dopamine at the $\mathrm{D}_{2} \mathrm{R}$ i.e. it is NAM of the efficacy of dopamine. The thienopyrimidine scaffold of $\mathbf{1}$ is unique to known dopaminergic receptor ligands. Therefore, a novel allosteric scaffold for the $\mathrm{D}_{2} \mathrm{R}$ has been identified and validated. Moreover, further validation has been provided for virtual allosteric ligand screening at the dopamine $\mathrm{D}_{2}$-like receptors.
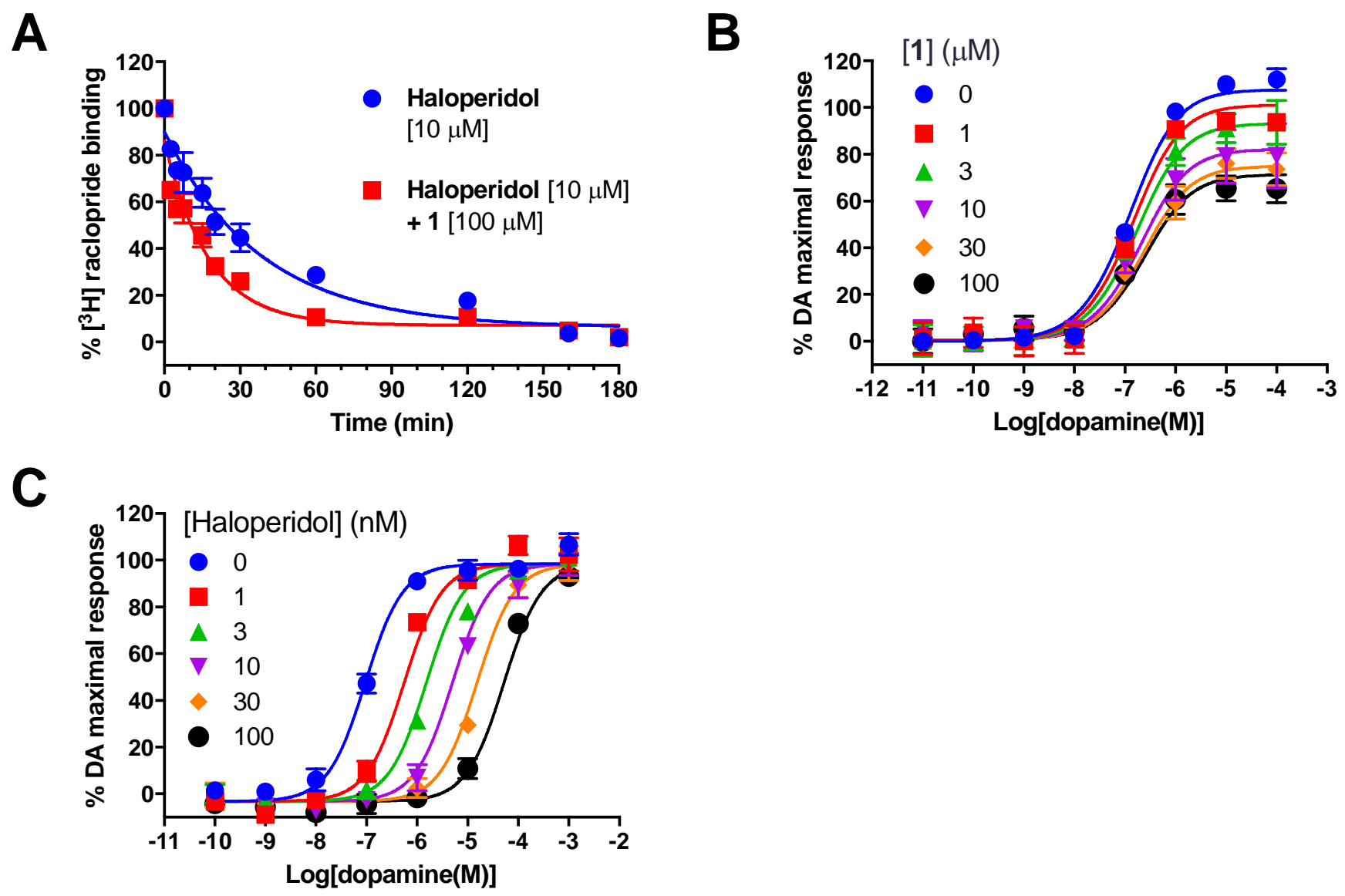

Figure 3. Compound 1 displays allosteric pharmacology at the $\mathbf{D}_{2} \mathbf{R}$. (A) 1 acts to increase the rate of dissociation of $\left[{ }^{3} \mathrm{H}\right]$ raclopride from the $\mathrm{hD}_{2 \mathrm{~L}} \mathrm{R}$ expressed in FlpIN $\mathrm{CHO}$ membranes consistent with an allosteric mode of action (Table 2). (B) In an assay measuring inhibition of forskolin-stimulated cAMP production using a BRET biosensor, 1 acts to cause limited depression in the maximal response of dopamine with more modest effects upon dopamine potency (these data were fitted with an operational model of allostery to derive values of affinity and cooperativity, Table 4). In constrast increasing concentrations of haloperidol (C) causes a limitless dextral shift in dopamine potency with no effect on dopamine maximal response 
consistent with competitive antagonism and can be fit with a Gaddum-Schild model to derive a value of affnity $\mathrm{pA}_{2}=9.67 \pm 0.10$. Data is the mean \pm SEM of three independent experiments performed in duplicate

Radioligand binding analysis of analogues of 1 : To begin to explore the structural features of $\mathbf{1}$ that determine its allosteric activity, we employed the equilibrium $\left[{ }^{3} \mathrm{H}\right]$ raclopride binding assay described in our characterisation of $\mathbf{1}$ above. For the majority of compounds, we observed complete displacement of the radioligand. Therefore, while this simple assay provides us with both confirmation of target activity and a value of affinity, for these compounds, we cannot distinguish between a competitive mode of interaction or an allosteric interaction that exerts high negative cooperativity upon $\left[{ }^{3} \mathrm{H}\right]$ raclopride binding. We first examined modifications to the fused cyclohexane system of 1 (Table 1). Replacement of the 6-membered saturated ring with a fused cyclopentane (14a) or cycoheptane (14b) system made no significant impact on binding affinity. However, replacement with the cyclooctane (14c) system caused a significant 6-fold decrease in affinity. No significant effect on affinity was seen when various other substituents were introduced to the 5- and 6-positions of the thienopyrimidinone (14d-g, i). Conversely, introduction of the 5-phenyl substituent (14e) did result in an apparent decrease in negative cooperativity manifested by an incomplete displacement of $\left[{ }^{3} \mathrm{H}\right]$ raclopride that allowed us to determine a value of cooperativity, $\alpha=0.13$ (Table 1). 5,6-Dimethyl substitution (14h), as well as removal of the fused system $(\mathbf{1 4} \mathbf{j})$ both caused a significant 5-10-fold decrease in affinity $\left(K_{\mathrm{B}}=250\right.$ and $120 \mu \mathrm{M}$, respectively). To further explore the role of the $N$-(3(trifluoromethyl)phenyl) substituent of $\mathbf{1}$, we generated a small series of analogues of $\mathbf{1}$ that incorporated changes to this functionality, including removal of the $\mathrm{CF}_{3}$ substituent (16a), as well as substitution with various groups $(3-\mathrm{F}, \mathbf{1 6 b}),\left(3-\mathrm{OCH}_{3}, \mathbf{1 6 c}\right),(\mathbf{3}-\mathrm{OH}, \mathbf{1 7})$. Removal of the $\mathrm{CF}_{3}$ substituent caused a 6-fold decrease in affinity whereas both the 3-OH and 3-OMe analogues displayed similar affinity to the parent compound (1). To investigate the effects of removing the $N$-(3-trifluoromethyl)phenyl substituent at the 4-position, we synthesised a series of analogues of $\mathbf{1}$ that included an $N, N$-dimethylamino group (15) that was isolated as a by-product from the synthesis of $\mathbf{1 4 \mathbf { f }}$ as a result of trialing DMF as a reaction solvent, as well as analogues bearing $N$-methylamino (18), and $N, N$-diethylamino (19) moieties. In addition to this, we investigated the effect of removing the secondary amine bridging the aryl moiety to the pyrimidine moiety of $\mathbf{1}$ by isosteric 
replacement with an ether linkage (20). These analogues all saw no significant change in affinity as compared to 1 . Interestingly, however, 19 displayed only partial displacement of $\left[{ }^{3} \mathrm{H}\right]$ raclopride at the $\mathrm{D}_{2} \mathrm{R}\left(K_{\mathrm{B}}=6.0\right.$ $\mu \mathrm{M}, \alpha=0.23$ ) (Table 1, Figure 4A). These data demonstrate that the secondary amine plays no role in the functional affinity of $\mathbf{1}$, but modification of this feature can modulate the negative cooperativity with $\left[{ }^{3} \mathrm{H}\right]$ raclopride. Additional analogues were synthesised to examine the effect of increasing the methylene linker length bearing the morpholine substituent (39a-c), as well as the effect of replacing either the oxygen or nitrogen atoms within morpholine with $\mathrm{CH}_{2}$ and $\mathrm{CH}(\mathbf{2 6} \& \mathbf{3 3 a}$, respectively, Table 1$)$. Of note, the addition of a morpholinobutyl substituent (39c) not only appeared to increase affinity 5-fold but also to cause an apparent decrease in negative cooperativity such that this compound was only able to partially inhibit the binding of $\left[{ }^{3} \mathrm{H}\right]$ raclopride $(\alpha=0.09)$. Interestingly, while incorporation of piperidine 26 saw no changes in affinity, the tetrahydropyran analogue 33a lost affinity and apparent negative cooperativity with $\left[{ }^{3} \mathrm{H}\right]$ raclopride as the highest concentration of 33a only partially displaced the radioligand from the receptor $\left(K_{\mathrm{B}}=100 \mu \mathrm{M}, \alpha=0.39\right)$ (Table 1, Figure 4A). Similarly, removal of the morpholinomethyl moiety 23a did not affect binding affinity despite having effects on negative cooperativity with only partial displacement the radioligand again observed $\left(K_{\mathrm{B}}=31 \mu \mathrm{M}, \alpha=0.39\right)$ (Table 1 , Figure $\left.4 \mathrm{~A}\right)$. In summary, the removal of the morpholinomethyl moiety, or incorporation of $N, N$-diethylamino, tetrahydropyranomethyl, and morpholinobutyl functionalities yielded ligands that exhibited incomplete displacement of $\left[{ }^{3} \mathrm{H}\right]$ raclopride, suggesting that these functionalities were important determinants of cooperativity (compounds 23a, 19, 33a, and 39c, respectively). Accordingly, analogues were synthesised integrating these changes with additional structural changes (Table 1). We synthesised four analogues combining the incorporation of the $N, N$ diethylamino moiety into these novel analogues of $\mathbf{1}$, including $\mathbf{2 3 b}$ (morpholinomethyl deletion), (33b) (tetrahydropyranomethyl), $\mathbf{4 0}$ (morpholinobutyl), and (44) (fused cyclohexane deletion). In addition to these modifications, we wanted to examine the effects of bis-functionalisation with respect to incorporating $m$ trifluoromethylaniline or $\mathrm{N}, \mathrm{N}$-diethylamine. We synthesised two compounds devoid of the fused cyclohexane system and morpholinomethyl moieties but maintained substitution with one of either $m$ trifluoromethylaniline or $N, N$-diethylamine, to reveal fragment-like low molecular weight analogues $(\mathbf{4 7 a} \&$ 47b respectively). While both maintained affinity at the $D_{2} R$, the latter compound was only able to partially 
displace $\left[{ }^{3} \mathrm{H}\right]$ raclopride and a value of $\alpha=0.10$ could be determined reflecting moderate negative cooperativity. Excitingly, our finding that $\mathbf{4 7 a}$ and $\mathbf{4 7 b}$, analogues both devoid of the fused system and morpholinomethyl moieties that maintain affinity, indicate that the scaffold of $\mathbf{1}$ can be 'pruned back' to reveal modulators of the $\mathrm{D}_{2} \mathrm{R}$ with low molecular weights and high ligand efficiencies. A further two compounds were synthesised that comprised the morpholinobutyl moiety but were devoid of the fused cyclohexane system, and were substituted with either $m$-trifluoromethyl-aniline or $N, N$-diethylamine (43a \& 43b respectively). Affinity was maintained for these analogues showing that the fused cyclohexane may be removed from the scaffold without detriment. It is interesting to note that $\mathbf{4 4}$ displayed 100 -fold improved affinity $\left(K_{\mathrm{B}}=1 \mu \mathrm{M}\right)$ from its parent analogue $\mathbf{1 4 j}\left(K_{\mathrm{B}}=120 \mu \mathrm{M}\right)$, demonstrating the $N$ - $N$-diethylamino substituent is favourable over the $m$-trifluoromethyl substituted aryl system. Similarly, upon introduction of this amine to 33a, compound 33b gained a 3-fold improvement in affinity $\left(K_{\mathrm{B}}=35 \mu \mathrm{M}\right)$, but acted to completely displace $\left[{ }^{3} \mathrm{H}\right]$ raclopride suggestive of higher negative cooperativity or a competitive mode of interaction. This is consistent with our observation that, while 23a partially displaced $\left[{ }^{3} \mathrm{H}\right]$ raclopride, compound $\mathbf{2 3 b}$ was able to completely displace the radioligand. In summary, then, our exploration of the thienopyrimidine scaffold of $\mathbf{1}$ revealed that a vast array of modifications are tolerated in terms of affinity for the $\mathrm{D}_{2} \mathrm{R}$ but that subtle modifications to the 4-position may modulate the degree of negative cooperativity between the allosteric ligand and orthosteric probe $\left[{ }^{3} \mathrm{H}\right]$ raclopride. As the degree of negative cooperativity on $\left[{ }^{3} \mathrm{H}\right]$ raclopride binding significantly changed upon $N, N$-diethylamino substitution (19), resulting in the incomplete displacement of the radioligand, we sought to obtain additional confirmation of an allosteric mode of interaction. The profile of $\mathbf{1 9}$ was further explored through radioligand binding dissociation kinetic experiments. In the presence of $\mathbf{1 9}$, the dissociation rate of the $\left[{ }^{3} \mathrm{H}\right]$ raclopride from the $\mathrm{D}_{2} \mathrm{R}$ again significantly increased (Table 2). This experiment provided further validation of the allosteric mode of action of $\mathbf{1}$ and its structural analogues. 
A

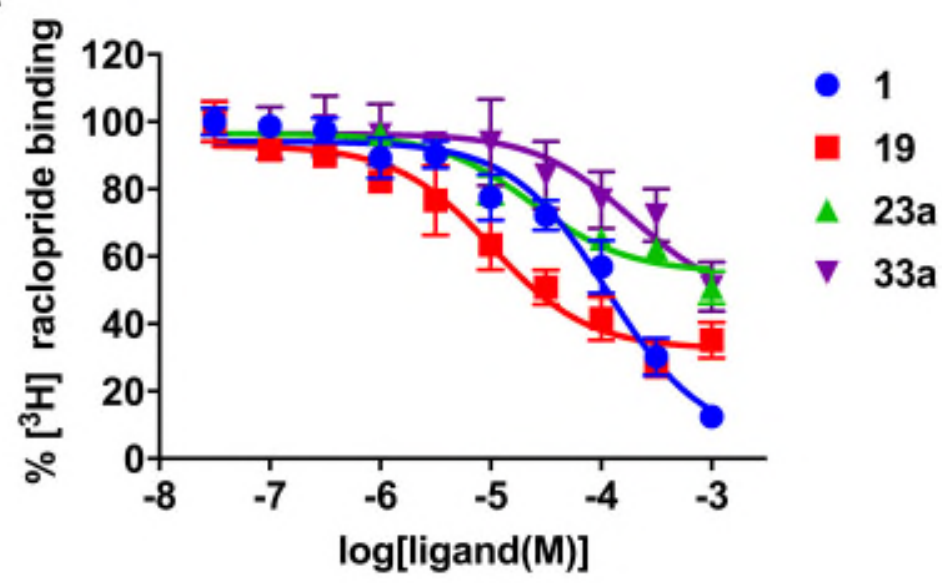

B

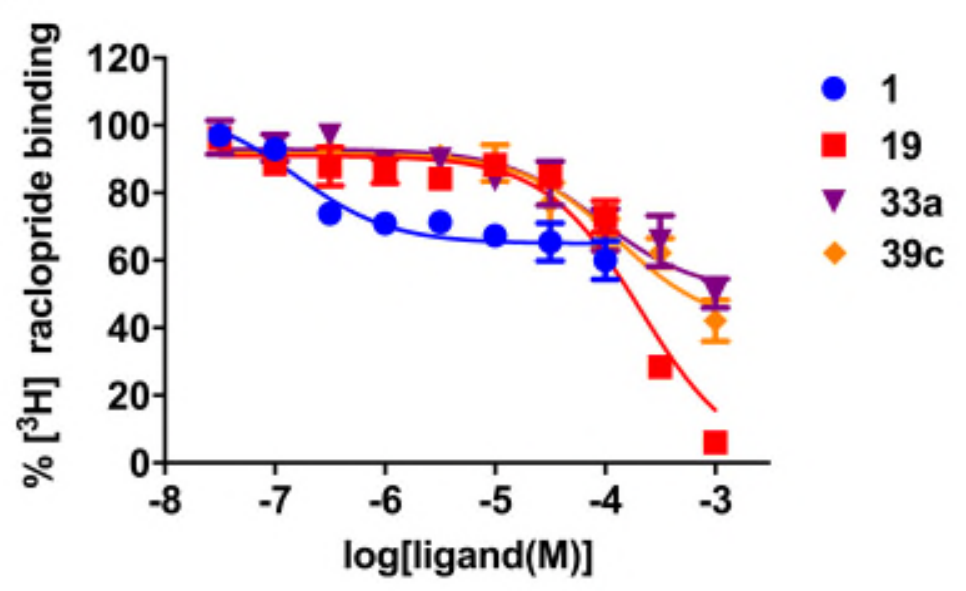

Figure 4. Analogues of 1 act to partially displace orthosteric radioligand binding at the $D_{2} R$ and $D_{3} R$. (A) In equilibrium radioligand binding experiments, $\mathbf{1}$ acts to completely displace $\left[{ }^{3} \mathrm{H}\right]$ raclopride from the $\mathrm{hD}_{2 \mathrm{~L}} \mathrm{R}$ expressed in FlpIN CHO membranes, an effect consistent with a competitive mode of binding or an allosteric mode of binding that exerts high negative cooperativity with $\left[{ }^{3} \mathrm{H}\right]$ raclopride (Table 1). In contrast compounds 19, 23a, and 33a act to only partially displace $\left[{ }^{3} \mathrm{H}\right]$ raclopride at the highest concentration consistent with an allosteric mode of action and moderate negative cooperativity (these data were fitted with an allosteric ternary complex model to derive estimates of affinity $\left(K_{\mathrm{B}}\right)$ and cooperativity with $\left[{ }^{3} \mathrm{H}\right]$ raclopride

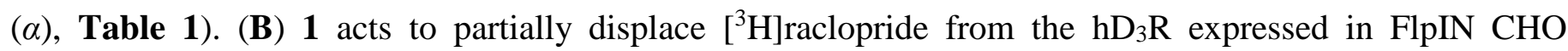
membranes at the highest concentration measured, whereas 19 completely displaces $\left[{ }^{3} \mathrm{H}\right]$ raclopride from the $\mathrm{D}_{3} \mathrm{R}$ (Table 3). Data is the mean \pm SEM of three independent experiments performed in duplicate. 
Table 1. Ability of 1 and derivatives of 1 to displace the radiolabelled antagonist $\left[{ }^{3} \mathrm{H}\right]$ raclopride at the $D_{2 L} R$ expressed in FlpIn CHO cells.

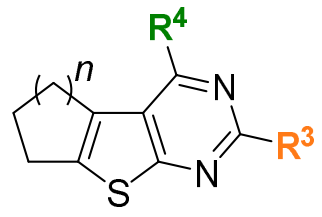

1, 14a-c, 16a-c, 17-20, 23a-b, 26, 33a-b, 39a-c, 40<smiles>[R]c1nc([R4])c2c([R])c([R])sc2n1</smiles>

14d-j, 15, 43a-b, 44, 47a-b

\begin{tabular}{|c|c|c|c|c|c|c|c|}
\hline & $n$ & $\mathbf{R}^{1}$ & $\mathbf{R}^{2}$ & $\mathbf{R}^{3}$ & $\mathbf{R}^{4}$ & $\begin{array}{c}\mathrm{p} K_{\mathrm{B}} \\
\left(K_{\mathrm{B}}, \mu \mathrm{M}\right)^{a}\end{array}$ & $\begin{array}{c}\log \alpha \\
(\alpha)^{b} \\
\end{array}$ \\
\hline 1 & 2 & - & - & & & $4.78 \pm 0.11(16.6)$ & - \\
\hline $14 a$ & 1 & - & - & & & $4.23 \pm 0.12(59)$ & - \\
\hline $14 b$ & 3 & - & - & & & $4.43 \pm 0.21(37)$ & - \\
\hline $14 c$ & 4 & - & - & & & $3.98 \pm 0.17(106)$ & - \\
\hline 14d & - & $\mathrm{H}$ & & & & $4.35 \pm 0.13(45)$ & - \\
\hline $14 \mathrm{e}$ & - & & $\mathrm{H}$ & & & $4.31 \pm 0.11(48.6)$ & $-0.88 \pm 0.10(0.13)$ \\
\hline $14 f$ & - & $\mathrm{H}$ & & & & $4.30 \pm 0.18(50)$ & - \\
\hline $14 \mathrm{~g}$ & - & & $\mathrm{H}$ & & & $4.42 \pm 0.20$ & - \\
\hline $14 h$ & - & $\mathrm{CH}_{3}$ & $\mathrm{CH}_{3}$ & & & $3.59 \pm 0.15(250)$ & - \\
\hline $14 \mathbf{i}$ & - & $\mathrm{H}$ & & & & $4.34 \pm 0.18(45.8)$ & - \\
\hline $14 j$ & - & $\mathrm{H}$ & $\mathrm{H}$ & & & $3.91 \pm 0.20(120)$ & - \\
\hline 15 & - & $\mathrm{H}$ & & & $(\mathrm{CH}$ & $4.51 \pm 0.14(30)$ & - \\
\hline $16 \mathbf{a}$ & 2 & - & - & & & $4.00 \pm 0.16(99)$ & - \\
\hline $16 b$ & 2 & - & - & & & nd & nd \\
\hline $16 \mathrm{c}$ & 2 & - & - & & & $4.32 \pm 0.14(48)$ & - \\
\hline 17 & 2 & - & - & & & $4.45 \pm 0.10(35)$ & - \\
\hline
\end{tabular}




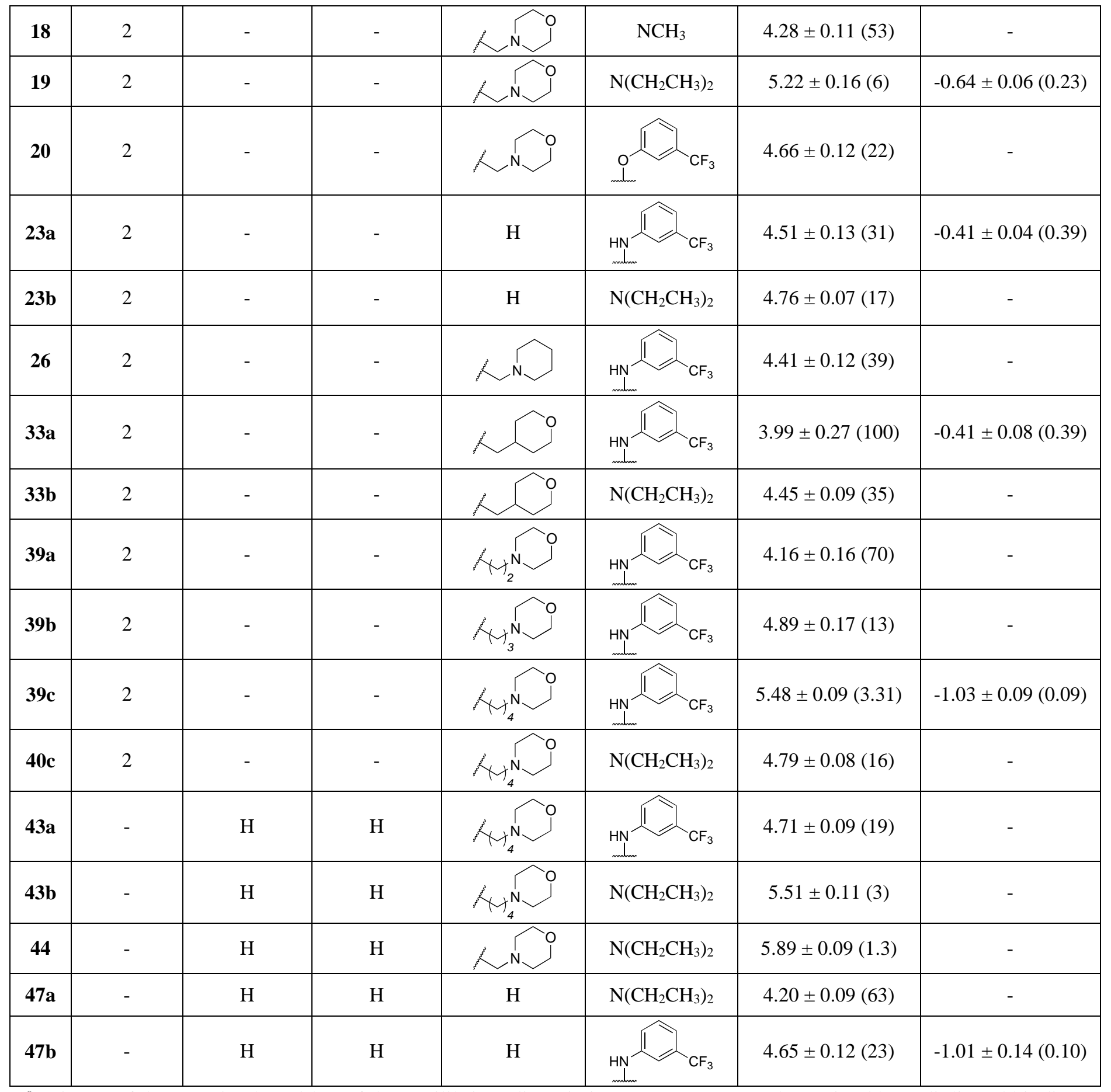

${ }^{a}$ Estimate of the negative logarithm of the equilibrium dissociation constant \pm SEM determined by radioligand binding. ${ }^{b}$ Estimate of the logarithm of the net cooperativity factor between the modulator and $\left[{ }^{3} \mathrm{H}\right]$ raclopride. Values represent the mean \pm SEM from at least three experiments performed in duplicate. 
Table 2. Compounds 1 and 19 act to increase the rate of $\left[{ }^{3} \mathrm{H}\right]$ Raclopride dissociation from membrane homogenates of FlpIn CHO Cells Stably Expressing the $\mathbf{D}_{2 \mathrm{~L}} \mathbf{R}^{{ }^{b}}$

\begin{tabular}{|c|c|c|c|c|}
\hline \multirow{2}{*}{} & \multicolumn{2}{|c|}{$\boldsymbol{k}_{\text {off }}\left(\mathbf{m i n}^{-\mathbf{1}}\right)$} & \multicolumn{2}{c|}{$\mathbf{t}_{1 / 2}$ (min) } \\
\cline { 2 - 5 } & haloperidol & $\begin{array}{c}\text { haloperidol }+ \\
\text { modulator }\end{array}$ & haloperidol & $\begin{array}{c}\text { haloperidol + } \\
\text { modulator }\end{array}$ \\
\hline $\mathbf{1}$ & ${ }^{a} 0.020 \pm 0.004$ & ${ }^{a} 0.038 \pm 0.005^{*}$ & ${ }^{a} 34.2$ & $a .1$ \\
\hline $\mathbf{1 9}$ & $0.014 \pm 0.001$ & $0.038 \pm 0.003^{*}$ & 49.2 & 18.2 \\
\hline
\end{tabular}

Values represent the mean \pm S.E.M. from at least three independent experiments performed in quadruplicate. *Analysis with a student's $t$-test revealed that $\left[{ }^{3} \mathrm{H}\right]$ raclopride displayed a significantly higher $(p<0.05) k_{\text {off }}$ in the presence of haloperidol plus modulator as compared to haloperidol alone.

Finally, we sought to assess receptor sub-type selectivity at the $\mathrm{D}_{3} \mathrm{R}$ versus the $\mathrm{D}_{2} \mathrm{R}$; accordingly, equilibrium radioligand binding experiments were conducted on $\mathbf{1}$ and a further seven structural analogues $\left(19,23 a, 33 a, 39 c, 40 c, 43 b\right.$ and 44, Table 3). Molecules were selected based upon their profiles at the $D_{2} R$ acquired from $\left[{ }^{3} \mathrm{H}\right]$ raclopride binding experiments at this receptor, where some showed increased binding affinites and divergent cooperativity profiles. Interestingly, two compounds displayed selectivity for the $\mathrm{D}_{2} \mathrm{R}$ over the $D_{3} R$ 39c (30-fold selectivity) and 44 (10-fold selectivity). In contrast, compounds 1,19 and $23 a$ displayed selectivity towards the $\mathrm{D}_{3} \mathrm{R}$ (57-fold, 23-fold, 140-fold, respectively). All other compounds displayed no significant subtype selectivity $(\mathbf{3 3 a}, \mathbf{4 0}, \mathbf{4 3 b})$. It is interesting to note that many compounds assayed at the $D_{3} R$ saw strikingly different levels of negative cooperativity with $\left[{ }^{3} \mathrm{H}\right]$ raclopride binding compared to that observed at the $\mathrm{D}_{2} \mathrm{R}$ (Table 3, Figure $4 \mathrm{~B}$ ). For example, at the $\mathrm{D}_{2} \mathrm{R}, 19$ only partially displaces $\left[{ }^{3} \mathrm{H}\right]$ raclopride at the highest concentration measured, however, at the $\mathrm{D}_{3} \mathrm{R}$ it completely displaces $\left[{ }^{3} \mathrm{H}\right]$ raclopride at the highest concentration despite having a lower functional binding affinity $\left(K_{\mathrm{B}}=89.7 \mu \mathrm{M}\right)$ (Table 3, Figure 4B). As 1 was identified via virtual ligand screening using a $D_{3} R$ crystal structure, it is unsurprising that $\mathbf{1}$ displayed subtype selectivity for this receptor. However, our study has identified $\mathrm{D}_{2} \mathrm{R}$ selective compounds that may be used as a starting point for the future development of $D_{2} R$ subtype-selective ligands. 
Table 3. Ability of 1 and derivaitives of 1 to displace the radiolabelled antagonist $\left[{ }^{3} \mathrm{H}\right]$ raclopride at the

\section{D3R expressed in FlpIn CHO cells}

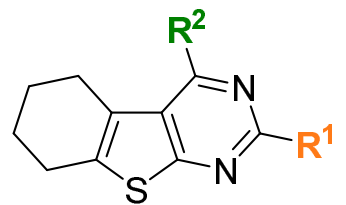

1, 19, 23a, 33a, 39c, 40c<smiles>[R]C1=CN2C(=C([2H])Sc3nc([R])c([R])c([R])c32)C([R])=N1</smiles>

43b, 44

\begin{tabular}{|c|c|c|c|c|c|}
\hline & $\mathbf{R}^{1}$ & $\mathbf{R}^{2}$ & $\begin{array}{c}{ }^{b} \mathbf{p} K_{\mathrm{B}} \\
\left(K_{\mathrm{B}}, \mu \mathrm{M}\right)\end{array}$ & $\begin{array}{c}\mathrm{D}_{2} / \mathrm{D}_{3} \\
\text { selectivity }\end{array}$ & $\begin{array}{c}{ }^{a} \log \alpha \\
(\alpha)\end{array}$ \\
\hline 1 & & & $6.54 \pm 0.27(0.3)$ & 57 & $-0.40 \pm 0.04(0.39)$ \\
\hline 19 & & $\mathrm{~N}\left(\mathrm{CH}_{2} \mathrm{CH}_{3}\right)_{2}$ & $3.85 \pm 0.16(140)$ & 23 & - \\
\hline 23a & $\mathrm{H}$ & & $6.65 \pm 0.21(0.2)$ & 140 & $-0.39 \pm 0.03(0.06)$ \\
\hline 33a & & & $4.28 \pm 0.23(52)$ & 2 & $-0.44 \pm 0.23(0.37)$ \\
\hline $39 c$ & & & $3.97 \pm 0.18(106)$ & 0.03 & $-0.69 \pm 0.20(0.20)$ \\
\hline 40 & & $\mathrm{~N}\left(\mathrm{CH}_{2} \mathrm{CH}_{3}\right)_{2}$ & $4.99 \pm 0.05(10)$ & 1.6 & - \\
\hline $43 b$ & & $\mathrm{~N}\left(\mathrm{CH}_{2} \mathrm{CH}_{3}\right)_{2}$ & $6.06 \pm 0.03(0.9)$ & 3.5 & - \\
\hline 44 & & $\mathrm{~N}\left(\mathrm{CH}_{2} \mathrm{CH}_{3}\right)_{2}$ & $4.95 \pm 0.06(11)$ & 0.1 & - \\
\hline
\end{tabular}

${ }^{a}$ Estimate of the negative logarithm of the equilibrium dissociation constant \pm SEM determined by radioligand binding.

${ }^{b}$ Estimate of the logarithm of the net cooperativity factor between the modulator and $\left[{ }^{3} \mathrm{H}\right]$ raclopride. Values represent the mean \pm SEM from at least three independent experiments performed in duplicate.

Functional Analysis (cAMP) of analogues of 1 . We extended our characterisation of these compounds to their effect upon dopamine action in the cAMP assay described above. Interestingly, all compounds above were shown to retain activity in our equilibrium radioligand binding experiments, yet many failed to have any effects upon dopamine binding and/or signalling efficacy within the same concentration range. This observation is likely an example of probe dependence whereby these ligands exert negative cooperativity on raclopride binding but display neutral cooperativity upon dopamine binding and efficacy. In agreement with this hypothesis, while our binding assay found that $\mathbf{1}$ displayed a robust effect upon $\left[{ }^{3} \mathrm{H}\right]$ raclopride binding, 
our functional data suggests that $\mathbf{1}$ acts to modulate dopamine efficacy but has little effect upon dopamine affinity.

We first examined modifications to the 5,6-fused cyclohexane system of $\mathbf{1}$ (Table 4). We found that increasing the fused ring size greater than 6-carbons renders these analogues inactive in this functional assay (14b-c), while the five-membered cyclopentane system (14a) maintained functional affinity $\left(K_{\mathrm{B}}=11.4 \mu \mathrm{M}\right)$ but changed the nature of the cooperativity whereby we observed a modulatory effect on dopamine affinity ( $\alpha$ $=0.13)$ rather than modulation of efficacy $(\beta=1)$. Both 6-phenyl substitution $(\mathbf{1 4 d})$ and modifications to the 5-position with phenyl (14e) or cyclohexyl (14g) substituents resulted in a loss of activity. Activity was maintained for the 6-cyclohexyl substituted analogue $\left(\mathbf{1 4 i}, K_{\mathrm{B}}=5.4 \mu \mathrm{M}\right.$, Figure $\left.5 \mathrm{~A}\right)$, but in contrast to the action of 1 that modulates dopamine efficacy, this ligand acted to modulate dopamine affinity only $(\alpha=0.13)$ (Table 4, Figure 5A). 5,6-Dimethyl substitution (14h), as well as removal of the fused functionality entirely $(\mathbf{1 4 j})$, rendered these analogues inactive in our functional assays, thus indicating a small window in which $\mathbf{1}$ can be modified surrounding the 5,6-positions and still maintain allosteric pharmacology with dopamine. Removal of the $\mathrm{CF}_{3}$ substituent on the aryl ring of $\mathbf{1}$ (16a, Table 5) or replacement with 3-F (16b), 3-OMe (16c) or 3-OH (17) had no effect upon functional affinity. However, the addition of methoxy or hydroxy substituents resulted in additional modulatory effects upon dopamine affinity $(\alpha=0.19$ and $\alpha=0.06$ respectively). 
A<smiles>FC(F)(F)c1cccc(Nc2nc(CN3CCOCC3)nc3sc(C4CCCCC4)cc23)c1</smiles>

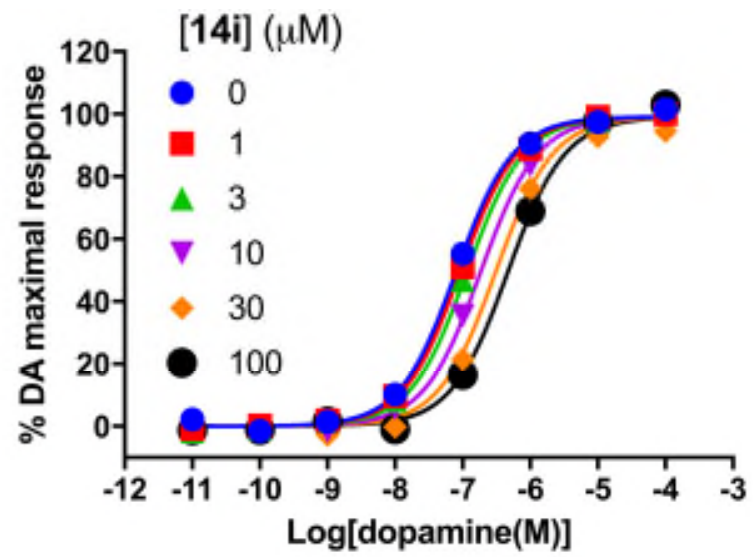

C
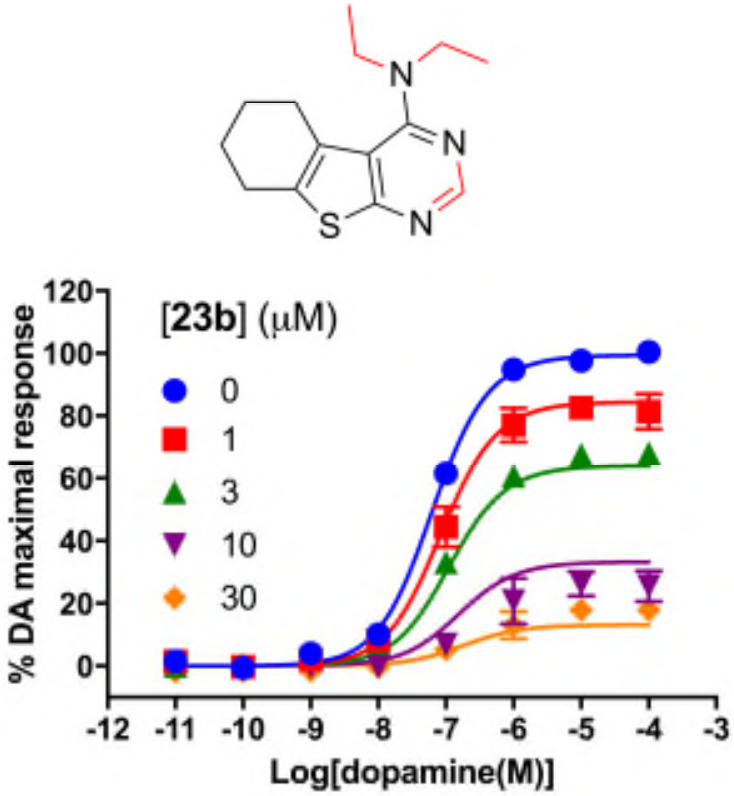

B<smiles>CCN(CC)c1nc(CN2CCOCC2)nc2sc3c(c12)CCCC3</smiles>

[19] $(\mu \mathrm{M})$

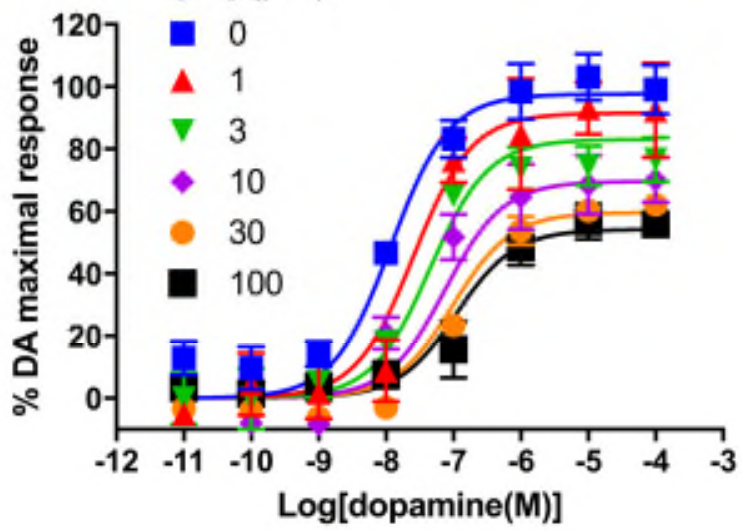

D
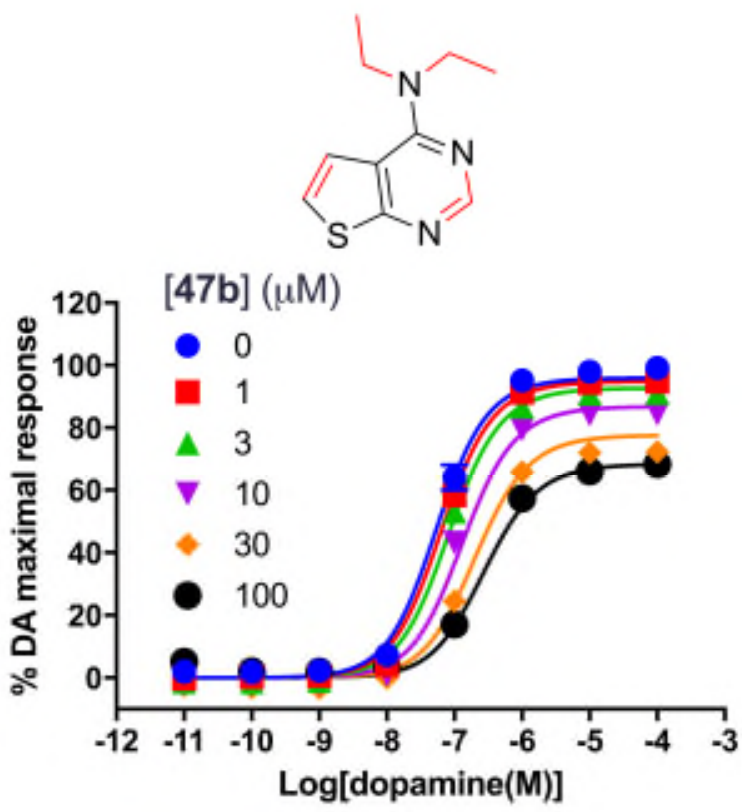

Figure 5. Exporation of the thieno[2,3- $d]$ pyrimidine scaffold of 1 reveals small molecule modulators of the $\mathbf{D}_{2 L} R$ with distinct functional effects. (A) Modification of the 5,6-fused system in the form of a 6cyclohexane substitution (14i, Table 4) resulted in negative cooperativity upon dopamine affinity with no effect upon dopamine efficacy (B). Replacement of the phenyl ring of 1 with $N, N$-diethyl (19, Table 6) caused a 6-fold increase in affinity and 4-fold increase in negative cooperativity with dopamine. (C) Removal of the morpholinomethyl moiety along with incorporation of the $N, N$-diethylamino substitution (23b, Table 7) maintained affinity but resulted in a large increase in negative cooperativity with dopamine efficacy. Remarkably, a fragment-like derivative devoid of both the morpholinomethyl and fused cyclohexane moieties 
but incorporating the $N, N$-diethylamino substitution $(\mathbf{4 7 b}$, Table 8) maintained functional affinity and displayed robust negative cooperativity with dopamine efficacy. All data are the mean \pm SEM of three independent experiments performed in duplicate. Data were fit using the operational model of allostery to derive estimates of affinity and cooperativity with dopamine.

Table 4. Functional Parameters for Analogues of 1 with Chemical Modifications to the 5,6-Fused System Derived from cAMP BRET Assay<smiles>[R]c1sc2nc(CN3CCOCC3)nc(Nc3cccc(C(F)(F)F)c3)c2c1[R]</smiles>

\begin{tabular}{|c|c|c|c|c|c|c|}
\hline & $n$ & $\mathbf{R}^{1}$ & $\mathbf{R}^{2}$ & $\begin{array}{c}{ }^{a} \mathrm{p} K_{\mathrm{B}} \\
\left(K_{\mathrm{B}}, \mu \mathrm{M}\right)\end{array}$ & $\begin{array}{c}{ }^{b} \log \alpha \\
(\alpha)\end{array}$ & $\begin{array}{c}{ }^{c} \log \beta \\
(\boldsymbol{\beta})\end{array}$ \\
\hline 1 & 1 & - & - & $5.41 \pm 0.22(3.87)$ & $=0$ & $-0.55 \pm 0.08(0.28)$ \\
\hline 14a & 2 & - & - & $4.95 \pm 0.40(11.4)$ & $-0.90 \pm 0.32(0.13)$ & $=0$ \\
\hline 14b & 3 & - & - & \multicolumn{3}{|c|}{ nd } \\
\hline $14 \mathrm{c}$ & 4 & - & - & \multicolumn{3}{|c|}{ nd } \\
\hline 14d & - & $\mathrm{H}$ & & \multicolumn{3}{|c|}{ nd } \\
\hline $14 \mathrm{e}$ & - & & $\mathrm{H}$ & \multicolumn{3}{|c|}{ nd } \\
\hline $14 f$ & - & $\mathrm{H}$ & & \multicolumn{3}{|c|}{ nd } \\
\hline $14 g$ & - & & $\mathrm{H}$ & \multicolumn{3}{|c|}{ nd } \\
\hline $14 \mathrm{~h}$ & - & $\mathrm{CH}_{3}$ & $\mathrm{CH}_{3}$ & \multicolumn{3}{|c|}{ nd } \\
\hline $14 \mathrm{i}$ & - & $\mathrm{H}$ & & $5.27 \pm 0.17(5.37)$ & $-0.90 \pm 0.11(0.13)$ & $=0$ \\
\hline $14 \mathrm{j}$ & - & $\mathrm{H}$ & $\mathrm{H}$ & \multicolumn{3}{|c|}{ nd } \\
\hline
\end{tabular}

${ }^{a}$ Estimate of the negative logarithm of the equilibrium dissociation constant determined in an cAMP functional assay.

${ }^{b}$ Estimate of the logarithm of the net cooperativity factor between the modulator and dopamine. ${ }^{c}$ Estimate of the logarithm of the modulatory effect upon efficacy factor induced by the allosteric modulator. nd = inactive at concentrations up to $100 \mu \mathrm{M}$. Values represent the mean \pm S.E.M. from at least three independent experiments performed in duplicate. 
Table 5. Functional Parameters for Analogues of 1 with Modifications to Aryl Moiety

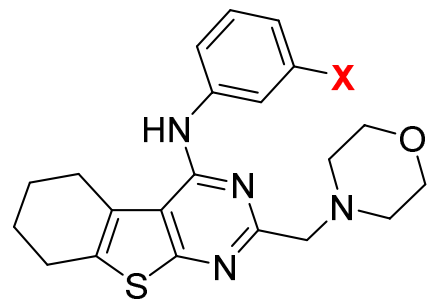

\begin{tabular}{|c|c|c|c|c|}
\hline & $\mathbf{X}$ & ${ }^{a} \mathbf{p} K_{\mathbf{B}}\left(K_{\mathbf{B}}, \boldsymbol{\mu M}\right)$ & ${ }^{b} \log \boldsymbol{\alpha}(\boldsymbol{\alpha})$ & ${ }^{c} \log \boldsymbol{\beta}(\boldsymbol{\beta})$ \\
\hline $\mathbf{1}$ & $\mathrm{CF}_{3}$ & $5.41 \pm 0.22(3.87)$ & $=0$ & $-0.55 \pm 0.08(0.28)$ \\
\hline $\mathbf{1 6 a}$ & $\mathrm{H}$ & $5.13 \pm 0.31(7.46)$ & $=0$ & $-0.95 \pm 0.24(0.11)$ \\
\hline $\mathbf{1 6 b}$ & $\mathrm{F}$ & $5.08 \pm 0.44(8.39)$ & $=0$ & $-0.40 \pm 0.11(0.40)$ \\
\hline $\mathbf{1 6 c}$ & $\mathrm{OMe}$ & $5.10 \pm 0.13(8.02)$ & $-0.73 \pm 0.16(0.19)$ & $-0.53 \pm 0.14(0.29)$ \\
\hline $\mathbf{1 7}$ & $\mathrm{OH}$ & $5.55 \pm 0.12(2.81)$ & $-1.22 \pm 0.16(0.06)$ & -3.0 \\
\hline
\end{tabular}

${ }^{a}$ Estimate of the negative logarithm of the equilibrium dissociation constant determined in an cAMP functional assay. ${ }^{b}$ Estimate of the logarithm of the net cooperativity factor between the modulator and dopamine. ${ }^{c}$ Estimate of the logarithm of the modulatory effect upon efficacy factor induced by the allosteric modulator. nd $=$ inactive at concentrations up to $100 \mu \mathrm{M}$. Values represent the mean \pm S.E.M. from at least three independent experiments performed in duplicate.

We then focused on the importance of the aryl ring within $\mathbf{1}$ by replacing the phenyl ring with acyclic aliphatic amines (Table 6). These analogues still maintained a hydrogen-bond donor-acceptor, but lacked the aromatic moiety in this region. The $N$-methylamino analogue (18) was inactive whereas the $N, N$-diethylamino analogue (19) saw a 6-fold increase in functional affinity and a 4-fold increase in negative cooperativity with dopamine efficacy $\left(K_{\mathrm{B}}=660 \mathrm{nM}, \beta=0.08\right.$, Figure 5B). To further probe the effects of this substituent, we tested an additional analogue of $\mathbf{1 9}$ in which the fused cyclohexane system was removed entirely whilst maintaining the $N, N$-diethyl functionality (44). While the analogue bearing no substitution at the 5- and 6-position (14j) displayed no activity in this functional assay, to our surprise compound 44 maintained affinity $\left(K_{\mathrm{B}}=3 \mu \mathrm{M}\right)$ as well as robust negative cooperativity with dopamine affinity and efficacy ( $\alpha=0.08, \beta=0.24)$. Interestingly, due to the presence of the $N, N$-dimethylamino functionality, 6-benzyl substitution (15) no longer rendered the molecule inactive, as seen previously with $\mathbf{1 4 f}$ (Table 4), but instead, caused affinity and negative allosteric cooperativity to be maintained (Table 6). Together, these data demonstrate that the nature of the 4-substituent (aromatic or acyclic aliphatic amine) has significant effects upon negative cooperativity with dopamine. 
Isosteric replacement of the secondary amine with an ether (20, Table 6) did not affect affinity in our binding assay, moreover this compound showed no activity in the functional assay highlighting the importance of the secondary amine contained within $\mathbf{1}$ and the potential requirement of a hydrogen-bond donor-acceptor at the 4-position for cooperativity with dopamine.

Table 6. Functional Parameters for Analogues of 1 with Chemical Modifications to the 4-position \& 5,6Fused System Derived from cAMP BRET Assay<smiles>[R3]c1nc(CN2CCOCC2)nc2sc3c(c12)CCCC3</smiles>

18-20<smiles>[R]c1sc2nc(CN3CCOCC3)nc([R])c2c1[R]</smiles>

15,44

\begin{tabular}{|c|c|c|c|c|c|c|}
\hline & $\mathbf{R}^{1}$ & $\mathbf{R}^{2}$ & $\mathbf{R}^{3}$ & $\begin{array}{c}{ }^{a} \mathbf{p} K_{\mathrm{B}} \\
\left(K_{\mathrm{B}}, \mu \mathrm{M}\right)\end{array}$ & $\begin{array}{c}{ }^{b} \log \alpha \\
(\alpha)\end{array}$ & $\begin{array}{c}{ }^{c} \log \beta \\
(\beta)\end{array}$ \\
\hline 15 & $\mathrm{H}$ & & $\mathrm{N}\left(\mathrm{CH}_{3}\right)_{2}$ & $5.31 \pm 0.15(4.90)$ & $-0.17 \pm 0.14(0.68)$ & $-0.84 \pm 0.10(0.15)$ \\
\hline 18 & & & $\mathrm{NCH}_{3}$ & \multicolumn{3}{|c|}{ nd } \\
\hline 19 & & & $\mathrm{~N}\left(\mathrm{CH}_{2} \mathrm{CH}_{3}\right)_{2}$ & $6.18 \pm 0.16(0.662)$ & $-0.17 \pm 0.17(0.68)$ & $-1.10 \pm 0.10(0.08)$ \\
\hline 20 & & & & \multicolumn{3}{|c|}{ nd } \\
\hline 44 & $\mathrm{H}$ & $\mathrm{H}$ & $\mathrm{N}\left(\mathrm{CH}_{2} \mathrm{CH}_{3}\right)_{2}$ & $5.50 \pm 0.10(3.13)$ & $-1.10 \pm 0.16(0.08)$ & $-0.62 \pm 0.15(0.24)$ \\
\hline
\end{tabular}

${ }^{a}$ Estimate of the negative logarithm of the equilibrium dissociation constant determined in an cAMP functional assay. ${ }^{b}$ Estimate of the logarithm of the net cooperativity factor between the modulator and dopamine. ${ }^{c}$ Estimate of the logarithm of the modulatory effect upon efficacy factor induced by the allosteric modulator. nd = inactive at concentrations up to $100 \mu \mathrm{M}$. Values represent the mean \pm S.E.M. from at least three independent experiments performed in duplicate.

Our binding experiments revealed that modifications at the 2-position of the thienopyrimidine can influence the degree of negative cooperativity between the modulator and $\left[{ }^{3} \mathrm{H}\right]$ raclopride. Therefore, we examined the functional impact of removing the morpholinomethyl moiety with respect to varying substituents at the 4-position. Maintaining the $m$-(trifluoromethyl)anilino substituent (23a) did not affect functional affinity but resulted in a 3 -fold increase in the modulatory effect upon dopamine efficacy $(\beta=0.10$, Table 7$)$. The 
$N, N$-diethylamino substituent (23b) not only maintained functional affinity $\left(K_{\mathrm{B}}=1 \mu \mathrm{M}\right)$, but gave rise to almost complete attenuation of dopamine signalling at a concentration of $10 \mu \mathrm{M}$ indiciative of a very high negative modulatory effect upon dopamine efficacy (Figure 5C, Table 7). Interestingly, the pyrimidinone analogue (21) was inactive and is in agreement with our finding that the secondary amine is a key structural determinant of cooperativity.

We next focused on the non-functionalised methylene spacer group within $\mathbf{1}$, and the importance of linker length (Table 7). Increasing linker length by one carbon atom had no effect on affinity, however the nature of allostery was altered as 39a modulated dopamine affinity with little effect upon dopamine efficacy $(\alpha=0.23)$. Further extension of linker length by one carbon $39 \mathbf{b}$ engendered an additional modulatory effect upon dopamine efficacy $\left(K_{\mathrm{B}}=1.39 \mu \mathrm{M}, \alpha=0.21, \beta=0.40\right)$. Moreover, further extension of the linker 39c was observed to not only increase functional affinity $\left(K_{\mathrm{B}}=611 \mathrm{nM}\right)$, but also increased negative cooperativity with dopamine efficacy $(\beta=0.03)$. The addition of the $N, N$-diethylamino substituent $(40)$ resulted in a similar affinity as determined for 39c, but displayed pharmacology best fit with a competitive model (Table 7).

Interestingly, isosteric replacement of the morpholino nitrogen with a methine group (33a) caused a 10-fold increase in functional affinity $\left(K_{\mathrm{B}}=622 \mathrm{nM}\right)$, as well as enhancing the negative allosteric modulatory effect upon dopamine efficacy $(\beta=0.13)$. This finding suggests that the ionizable nitrogen within $\mathbf{1}$ is not a structural requirement to maintain modulatory activity at the $\mathrm{D}_{2} \mathrm{R}$. However, the $N$ - $N$-diethylamino substitution (33b) was not tolerated in conjunction with the tetrahydropyran as the compound was inactive in this functional assay. Isosteric replacement of the morpholino oxygen for a methylene group via the incorporation of piperidine (26) maintained functional affinity $\left(K_{\mathrm{B}}=6.52 \mu \mathrm{M}\right)$, but saw a reduction in negative allosteric cooperativity ( $\alpha=0.49, \beta=0.68)$ compared to 33a. 
Table 7. Functional Parameters for Analogues of 1 with Chemical Modifications to the 2-Position

\section{Derived from cAMP BRET Assay}

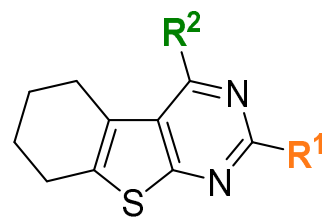

\begin{tabular}{|c|c|c|c|c|c|}
\hline & $\mathbf{R}^{1}$ & $\mathbf{R}^{2}$ & $\begin{array}{c}{ }^{a} \mathbf{p} K_{\mathrm{B}} \\
\left(K_{\mathrm{B}}, \mu \mathrm{M}\right)\end{array}$ & $\begin{array}{c}{ }^{b} \log \alpha \\
(\alpha)\end{array}$ & $\begin{array}{c}{ }^{c} \log \beta \\
(\beta)\end{array}$ \\
\hline 21 & $\mathrm{H}$ & $\mathrm{C}=\mathrm{O}$ & \multicolumn{3}{|c|}{ nd } \\
\hline 23a & $\mathrm{H}$ & & $4.60 \pm 0.17(25.4)$ & $=0$ & $-1.02 \pm 0.35(0.10)$ \\
\hline $23 b$ & $\mathrm{H}$ & $\mathrm{N}\left(\mathrm{CH}_{2} \mathrm{CH}_{3}\right)_{2}$ & $5.72 \pm 0.13(1.92)$ & $=0$ & $=-3.0$ \\
\hline 26 & & & $-5.16 \pm 0.13(6.98)$ & $-0.46 \pm 0.12(0.34)$ & $-0.22 \pm 0.08(0.60)$ \\
\hline 33a & & & $6.22 \pm 0.26(0.622)$ & $-0.89 \pm 0.29(0.13)$ & $-0.63 \pm 0.19(0.23)$ \\
\hline $33 \mathbf{b}$ & & $\mathrm{N}\left(\mathrm{CH}_{2} \mathrm{CH}_{3}\right)_{2}$ & \multicolumn{3}{|c|}{ nd } \\
\hline $39 a$ & & & $6.01 \pm 0.17(0.981)$ & $-0.63 \pm 0.05(0.23)$ & $=0$ \\
\hline 39b & & & $5.79 \pm 0.11(1.63)$ & $-0.68 \pm 0.12(0.21)$ & $-0.40 \pm 0.08(0.40)$ \\
\hline $39 c$ & & $\mathrm{CF}_{3}$ & $6.21 \pm 0.11(0.611)$ & $-0.72 \pm 0.18(0.19)$ & $-1.50 \pm 0.15(0.03)$ \\
\hline 40 & & $\mathrm{~N}\left(\mathrm{CH}_{2} \mathrm{CH}_{3}\right)_{2}$ & $5.80 \pm 0.20(1.77)$ & ${ }^{e}$ Schild Slop & $1.07 \pm 0.11$ \\
\hline
\end{tabular}

${ }^{a}$ Estimate of the negative logarithm of the equilibrium dissociation constant \pm SEM determined in an cAMP functional assay. ${ }^{b}$ Estimate of the logarithm of the net cooperativity factor between the modulator and dopamine \pm SEM determined in an cAMP functional assay. $\mathrm{nd}=$ inactive at concentrations up to $100 \mu \mathrm{M}$. Values represent the mean \pm S.E.M. from at least three independent experiments performed in duplicate.

We also investigated the impact of bis-functionalisation of $\mathbf{1}$ with respect to incorporating various amines at the 4-position of $\mathbf{1}$ in this functional assay (Table 8). Two analogues of $\mathbf{1}$ that incorporate the morpholinobutyl substituent, in conjunction with removal of the fused cyclohexane system, together with one of either $m$ - $\mathrm{CF}_{3}$-anilino (43a) or $N, N$-diethylamino substituents $(\mathbf{4 3 b})$ maintained functional affinity $\left(K_{\mathrm{B}}=1.3\right.$ $\mu \mathrm{M}$ and $1.4 \mu \mathrm{M}$, respectively) comparable to $\mathbf{1}$, but now displayed a higher level of negative cooperativity 
with both dopamine affinity and efficacy (Table 8). These data further indicate that linker length extension of the morpholine moiety acts to increase negative cooperativity with dopamine.

Table 8. Functional Parameters for Analogues of 1 with Bi-Functionalisation in Conjunction with Aromatic or Aliphatic 4-Substituted Amine

In agreement with our binding data, analogues of $\mathbf{1}$ devoid of both the morpholinomethyl and fused cyclohexane moieties but incorporating one of either $m$-(trifluoromethyl)aniline (47a), or $N, N$-diethylamine (47b, Figure 5D) maintained functional affinity and displayed robust negative cooperativity with dopamine efficacy and affinity despite the lack of a substituent at the 2-position or the presence of the fused cyclohexane system $\left(K_{\mathrm{B}}=1.3 \mu \mathrm{M}, \alpha=0.05, \beta=0.15\right.$ and $K_{\mathrm{B}}=1.4 \mu \mathrm{M}, \alpha=0.13, \beta=0.06$, respectively, table 8$)$. These data demonstrate the utility of the thieno[2,3-d]pyrimidine scaffold as a NAM of the dopamine effect as 'pruned back' analogues maintain negative allosteric cooperativity whilst preserving functional affinity relative to $\mathbf{1}$. Through successive compound iterations, both the lipophillic ligand efficiency (LLE) and ligand efficiency (LE) of the scaffold have been enhanced significantly compared to that of $\mathbf{1}$, with the most efficient 
compound being $\mathbf{4 7 b}$ (Figure $6, \mathrm{LLE}=2.48, \mathrm{LE}=0.54$ ). This reveals the versatility of the scaffold for further structural optimisation and development of ligands that non-competitively modulate dopamine affinity and signalling efficacy at the $\mathrm{D}_{2} \mathrm{R}$. Collectively, these results demonstrate that analogues of $\mathbf{1}$ mediate their effects through an allosteric mode of action. While we were able to gain only relatively modest (10-fold) improvement in affinity, our SAR study revealed compounds with a range of modulatory effects upon dopamine efficacy and/or affinity.

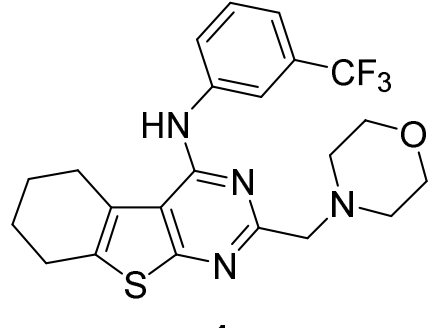

1

MW: 449

LLE: -0.39

LE: 0.24

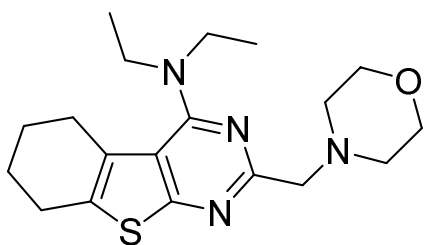

19

MW: 360

LLE: 1.99

LE: 0.35

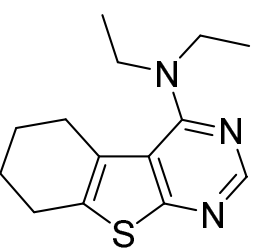

23b

MW: 261

LLE: 1.28

LE: 0.44

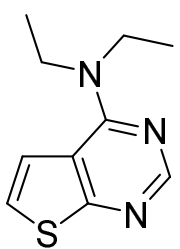

47b

MW: 207

LLE: 2.48

LE: 0.54

Figure 6. Lipophillic ligand efficiencies (LLE), and ligand efficiencies (LE) of 1, 19, 23b, and 47b calculated according to equilibrium dissociation constants derived from functional interaction experiments measuring cAMP accumulation. Multiple compound iterations have yielded improvements in the scaffold's efficiency through decreased molecular weight and functional binding affinity. This is particularly evident with compound $\mathbf{4 7 \mathbf { b }}$ as it shows a marked improvement in both LLE and LE compared to that of $\mathbf{1}$, resulting in a promising fragment-like starting scaffold that can be elaborated through multiple vectors.

Molecular Docking Studies. The recently solved structure of $\mathrm{D}_{2} \mathrm{R}$ receptor (PDB ID: $\left.6 \mathrm{C} 38\right)^{32}$ provides an opportunity to accurately model the allosteric binding of compound $\mathbf{1}$ and a library of structurally diverse analogues. Specifically, we were interested in the interactions of these allosteric compounds with the orthosteric ligand, as reflected in the $\left[{ }^{3} \mathrm{H}\right]$ raclopride equilibrium binding assays (Table 1 ). While the $\mathrm{D}_{2} \mathrm{R}$ structure was solved with the atypical antipsychotic drug risperidone, we first generated a conformational model of raclopride bound to the $\mathrm{D}_{2} \mathrm{R}\left(\mathrm{D}_{2} \mathrm{R}^{\text {Raclo }}\right)$. Flexible docking of raclopride shows a pose similar to the pose of eticlopride found in the $\mathrm{D}_{3} \mathrm{R}$ structure. Both raclopride and eticlopride are known to bind to the 
orthosteric pocket of the $\mathrm{D}_{2} \mathrm{R}$ commonly occupied by dopamine, however, since it is bulkier than dopamine, the allosteric pocket in the $\mathrm{D}_{2} \mathrm{R}^{\text {Raclo }}$ complex is shallower, as compared to the $\mathrm{D}_{2} \mathrm{R}^{\text {Dopa }}$ complex.

Docking of compound $\mathbf{1}$ in the $\mathrm{D}_{2} \mathrm{R}^{\text {Raclo }}$ complex consistently yielded the best scoring pose shown in Figure 7. This pose is stabilised by a hydrogen bond between the ionised morpholine secondary amine and the oxygen atom of the side-chain of $S 409^{7.36}$ (Ballesteros-Wenstein nomenclature ${ }^{33}$ ), as well $\pi$ - $\pi$ stacking interactions of the thienopyrimidine moiety with $\mathrm{Y}_{40} 8^{7.35}$ and $\mathrm{W} 100^{\mathrm{ECL} 1}$ side chains. In addition, the fused cyclohexane ring system is positioned in the hydrophobic sub-pocket located between helices V and VI formed by the residues I184ECL2, V190 $0^{5.39}, \mathrm{H} 394^{6.55}$, whereas the phenyl ring bearing the $m-\mathrm{CF}_{3}$ substituent is placed between helices VI and VII, and ECL3, and is lined by the residues N396 $6^{6.58}, \mathrm{~N} 402^{\mathrm{ECL} 3}, \mathrm{P} 405^{7.32}$, and Y408 ${ }^{7.35}$ (Figure 7).

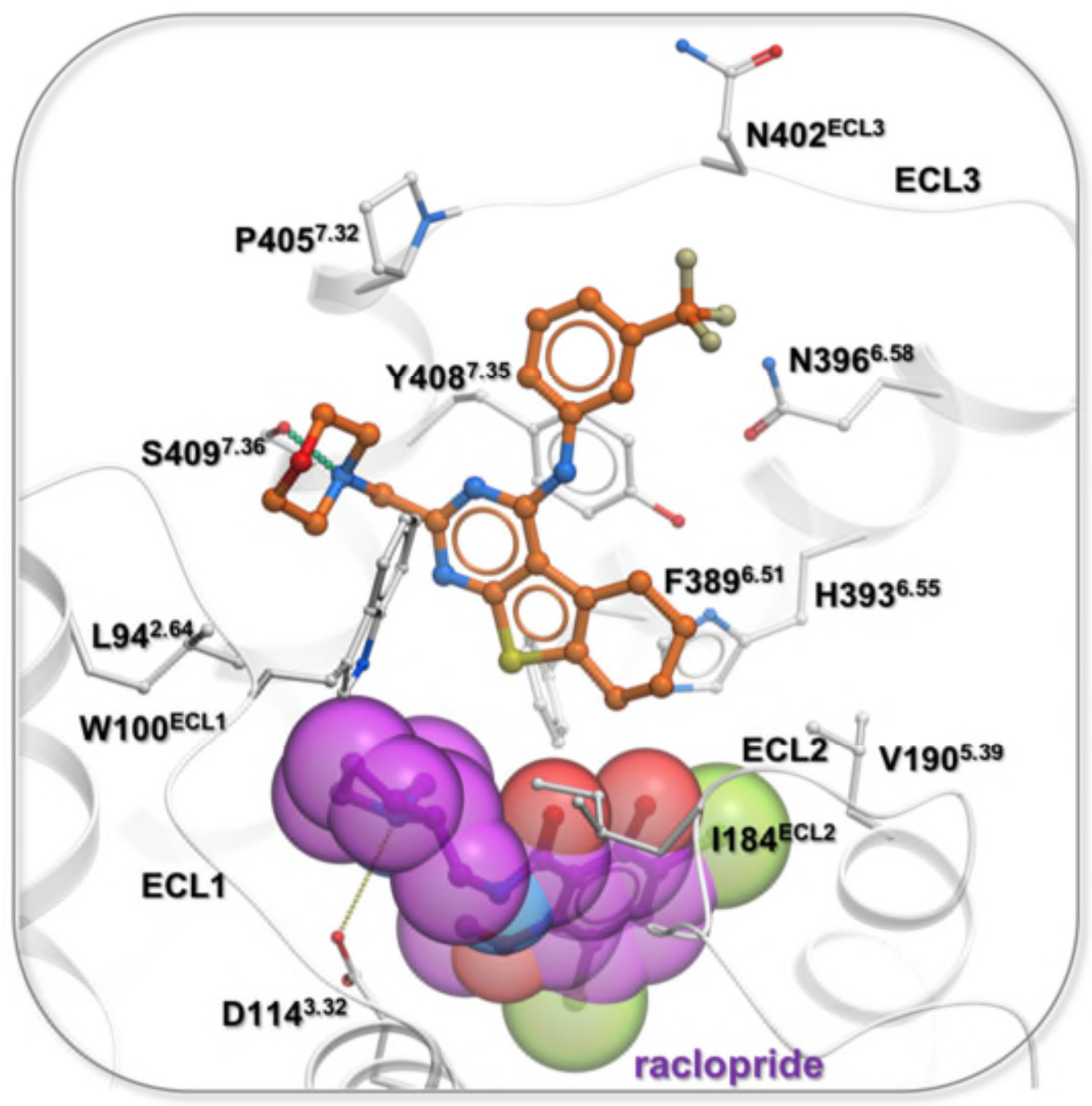

Figure 7. Compound 1 (orange carbon atoms) predicted binding mode in complex with raclopride (magenta carbon atoms) $\left(\mathrm{D}_{2} \mathrm{R}^{\mathrm{Raclo}}\right.$ conformational model (PDB ID: 6C38)). $\mathrm{D}_{2} \mathrm{R}$ structural model is shown in light grey cartoon and stick presentation. 
The key SAR data support the consistent binding pose of compound $\mathbf{1}$ and its analogues as illustrated in Figure 8 and Supplementary Figure 2. First, we examined modifications to the fused cyclohexane system of 1, (14aj). Most analogues bind in a similar mode, maintaining the key interactions of the scaffold (Supplementary Figure 2A). At the same time, the docking illustrates a modest binding dependence on the size of this fused hydrophobic ring, as replacement of the cyclohexane with either cyclopentane (14a) or cycloheptane $(\mathbf{1 4 b})$ would make less favorable hydrophobic interactions, reducing allosteric binding affinity by $~ 2-4$-fold (Figure 8A). Moreover, compounds that lack the fused ring system $(\mathbf{1 4 h}, \mathbf{j})$ showed an even more pronounced decrease in binding, consistent with loss of interactions with this hydrophobic sub-pocket (Figure 8B).

Next, we examined compounds with variations to in the $m-\mathrm{CF}_{3}$ substituent $(\mathbf{1 6 a - c , ~ 1 7 ) ~ p o s i t i o n e d ~ b e t w e e n ~}$ helices VI and VII, and ECL3, but exposed to solvent. As the $\mathrm{CF}_{3}$ substituent is favorable for solvent interactions, its removal in 16a explains the observed 6-fold decrease in binding for this compound. The reduction is much smaller for derivatives that have polar substituents in this position, 3-OH (17) and 3-OMe (16c) (Supplementary Figure 2B).

Next, we examined compounds with variations in $N$-(3-trifluoromethyl)phenylamino substituent $(\mathbf{1 5}, \mathbf{1 8}, \mathbf{1 9})$. The docking poses place $N, N$-dimethylamino (15), $N$-methylamino (18), and $N, N$-diethylamino moieties (19) into the hydrophobic sub-pocket in the proximity of $\mathrm{Y}_{40} 8^{7.35}$ and $\mathrm{W} 100^{\mathrm{ECL} 1}$, with $\mathbf{1 9}$ having the most extensive hydrophobic contacts. This is in agreement with an improved binding affinity for $\mathbf{1 9}$ (Supplementary Figure 2C). The secondary amine of compound $\mathbf{1}$ is not engaged in any interactions, and its isosteric replacement to an ether (20) did not impact the predicted binding mode (Supplementary Figure 2D), nor its binding affinity (Table 1).

Interestingly, removal of the morpholinomethyl moiety (23a) maintained the $\pi$ - $\pi$ stacking interactions of the thienopyrimidine moiety with the $\mathrm{Y} 408^{7.35}$ and $\mathrm{W} 100^{\mathrm{ECL} 1}$, though slightly shifting the scaffold, enabling an additional hydrogen bond interaction with $\mathrm{T} 412^{7.39}$. We hypothesize that though loss of the morpholine system abolished the interaction with the $\mathrm{S} 409^{7.36}$ (Figure 8C), the new hydrogen bond at least partially compensated the loss, maintaining binding affinity of this analogue (Table 1). However, replacing morpholine with 
piperidine (26) leads to 2.5 -fold decrease in affinity, reflecting replacement of a polar oxygen with a carbon in this solvent-exposed position (Supplementary Figure 2E).

Moreover, removal of the tertiary amine in the morpholine ring abolishes the hydrogen bond interaction of 33a with $\mathrm{S} 409^{7.36}$ (Figure 8D), with the importance of this hydrogen bond corroborated by a $\sim 7$-fold decrease in affinity for this compound (Table 1).

Furthermore, we evaluated the effect of elongating the methylene linker to the morpholine substituent (39ac). In our model, increasing the linker length did not hinder the ability of the compounds to maintain crucial interactions, and even helped to improve complementarity of $39 \mathrm{c}$ with the binding pocket, in accordance with its improved affinity (Figure 8E).

Other docked analogues, characterised by morpholinomethyl deletion (23b), tetrahydropyranomethyl (33b), morpholinobutyl (40), and fused cyclohexane deletion (44), also maintained the crucial $\pi-\pi$ interactions with Y $408^{7.35}$ and W100 ${ }^{\mathrm{ECL} 1}$ (Supplementary Figure 2F). Similar poses were obtained for the two compounds 43ab, comprised of the morpholinobutyl moiety and four carbon linker, but devoid of the fused cyclohexane system (Supplementary Figure 2G).

Finally, we docked compounds devoid of the fused cyclohexane system and morpholinomethyl moieties but maintained substitution with one of either $m$-trifluoromethylanilino or $N, N$-diethylamino (47a-b). This dramatically reduced the size of the scaffold, but also maintained $\pi-\pi$ stacking interactions with Y $408^{7.35}$ and $\mathrm{W} 100^{\mathrm{ECL} 1}$, while shifting to gain a hydrogen bond interaction with $\mathrm{T} 412^{7.39}$ (Figure $8 \mathrm{~F}$ ), which is in agreement with only a minor loss of binding affinity (Table 1). 

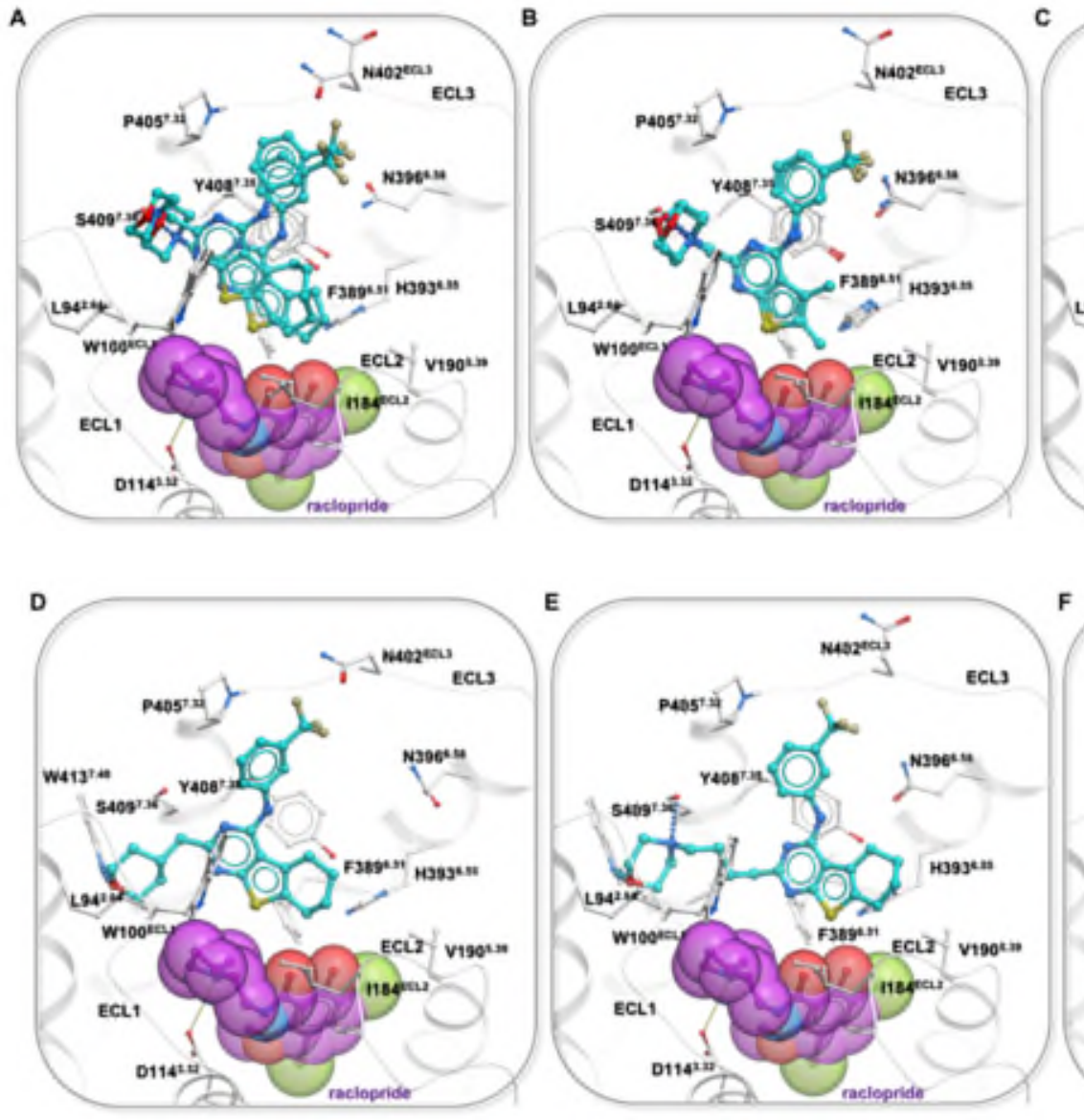

\section{- CONCLUSIONS}
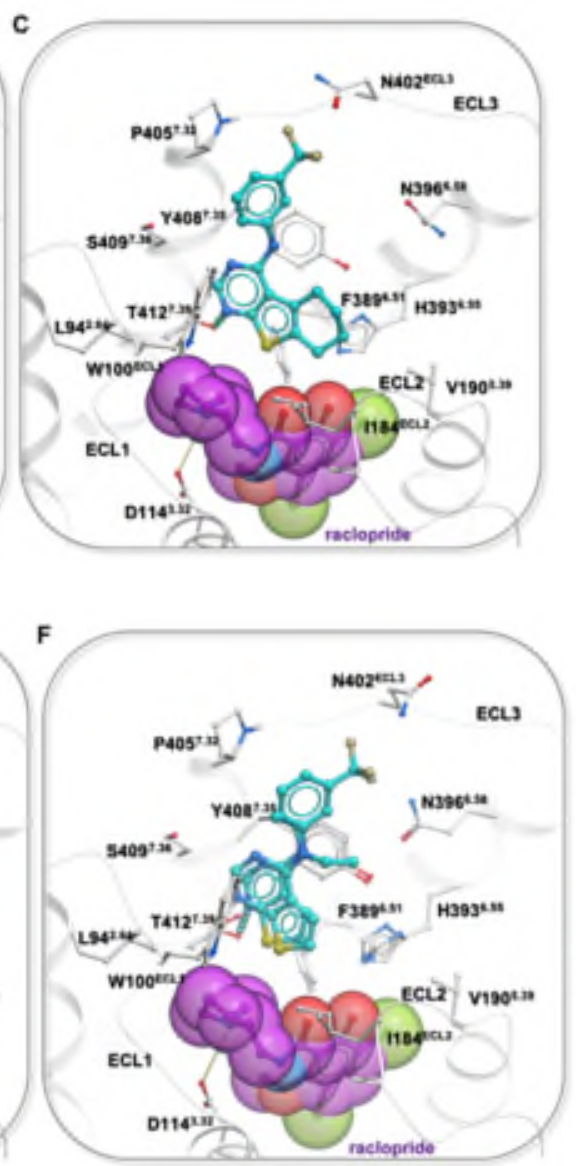

Figure 8. Compound 1 analogues in complex with $\mathrm{D}_{2} R^{\mathrm{Raclo}}$ (PDB ID: 6C38). Compounds with variation in the fused cyclohexane system: (A) Compounds 14a, c. (B) Compounds 14h, j. (C) Compound devoid of morpholinomethyl moiety (23a). (D) Compound with tetrahydropyran moiety (33a). (E) Compounds with variations in alkyl linker length to the morpholine motif (39c). (F) Fragment-like compounds (47a-b).

In this study, we report the pharmacological validation of a VLS hit, confirming it exerts its effect via an allosteric mode of action at the $\mathrm{D}_{2} \mathrm{R}$, as predicted by our initial modeling studies. We subsequently describe the design and characterisation of a structurally novel series of dopamine $\mathrm{D}_{2} \mathrm{R}$ NAMs based on this thieno[2,3d]pyrimidine scaffold, demonstrating its scope for future development of $\mathrm{D}_{2} \mathrm{R}$ NAMs. The impact of structural modification was assessed with respect to thienopyrimidine substituents (2-, 4-, 5- and 6-positions), isosteric replacement of the aniline nitrogen with respect to hydrogen-bonding, as well as the importance of bearing an 
ionisable nitrogen at differing linker lengths on the 2-substituent and its subsequent impact on the allosteric pharmacology of $\mathbf{1}$. The majority of active compounds displayed comparable binding affinities to that of $\mathbf{1}$. Rather, the structural modifications within this study had a profound effect upon the extent of modulation of dopamine binding and/or efficacy. Indeed, while 1 exerted its effect predominaly via negative modulation of dopamine efficacy, we identified analogues of $\mathbf{1}$ that displayed modulatory effects upon dopamine affinity (e.g. 14a, 14i, 39a), and those that displayed modulatory effects upon both dopamine affinity and efficacy (e.g. 17, 19, 43a). Maintaining a hydrogen-bond donor (secondary amine) at the 4-position was found to be a requirement for cooperativity with dopamine, as thienopyrimidinone analogues were inactive in our functional assay. Moreover, the ether analogue of $\mathbf{1}$ (20) was also inactive in our functional assay, suggesting this modification is not well tolerated. Most significantly, we show that this scaffold can be effectively 'pruned back' of morpholinomethyl and fused cyclohexane moieties, to reveal a low molecular weight fragment-like core with low $\mu \mathrm{M}$ functional affinity and very high lipophilic ligand efficiency (47a-b). Our molecular docking studies, using the recently determined crystal structure as a template, provide some insight into the molecular determinants of this SAR. Thus, this minimal thieno[2,3- $d$ ]pyrimidine scaffold provides an attractive starting point for further structural interrogation and elaboration of the core scaffold to achieve high affinity, low molecular weight NAMs of the $\mathrm{D}_{2} \mathrm{R}$ with varying effects upon dopamine binding and/or function.

\section{- EXPERIMENTAL SECTION:}

Chemistry: General Information and Synthetic Procedures. Chemicals and solvents were purchased from standard suppliers and used without further purification. Davisil silica gel $(40-63 \mu \mathrm{m})$ for flash column chromatography was supplied by Grace Davison Discovery Sciences (Victoria, Australia), and deuterated solvents were purchased from Cambridge Isotope Laboratories, Inc. (USA, distributed by Novachem PTY. Ltd., Victoria, Australia). Reactions were monitored by thin layer chromatography on commercially available precoated aluminum-backed plates (Merck Kieselgel $60 \mathrm{~F}_{254}$ ). Visualisation was by examination under UV light (254 and $366 \mathrm{~nm}$ ). A solution of ninhydrin (in ethanol) was used to visualise primary and secondary amines. All organic extracts collected after aqueous workup procedures were dried over anhydrous $\mathrm{MgSO}_{4}$ or $\mathrm{Na}_{2} \mathrm{SO}_{4}$ before gravity/vacuum filtering and evaporation to dryness. Organic solvents were evaporated in 
vacuo at $\leq 40{ }^{\circ} \mathrm{C}$ (water bath temperature). ${ }^{1} \mathrm{H}$ NMR and ${ }^{13} \mathrm{C}$ NMR spectra were recorded on a Bruker Avance Nanobay III 400 MHz Ultrashield Plus spectrometer at 400.13 and $100.62 \mathrm{MHz}$, respectively. Chemical shifts $(\delta)$ are recorded in parts per million $(\mathrm{ppm})$ with reference to the chemical shift of the deuterated solvent. Coupling constants $(J)$ are recorded in $\mathrm{Hz}$, and the significant multiplicities described by singlet (s), doublet $(d)$, triplet $(\mathrm{t})$, quadruplet $(\mathrm{q})$, broad (br), multiplet $(\mathrm{m})$, doublet of doublets (dd), and doublet of triplets (dt). Spectra were assigned using appropriate COSY, distortionless enhanced polarization transfer (DEPT), HSQC, and HMBC sequences. LC-MS were run to verify reaction outcome and purity using an Agilent 6120 series single quad coupled to an Agilent 1260 series HPLC. The following buffers were used: buffer A, $0.1 \%$ formic acid in; buffer B, $0.1 \%$ formic acid in MeCN. The following gradient was used with a Poroshell 120 EC-C18 $50 \mathrm{~mm} \times 3.0 \mathrm{~mm} 2.7 \mu \mathrm{m}$ column, and a flow rate of $0.5 \mathrm{~mL} / \mathrm{min}$ and total run time of $5 \mathrm{~min} ; 0-1 \mathrm{~min} 95 \%$ buffer A and 5\% buffer B, from 1 to 2.5 min up to $0 \%$ buffer A and $100 \%$ buffer B, held at this composition until 3.8 min, 3.8-4 min 95\% buffer A and 5\% buffer B, held until 5 min at this composition. Mass spectra were acquired in positive and negative ion mode with a scan range of $100-1000 \mathrm{~m} / \mathrm{z}$. UV detection was carried out at 214 and $254 \mathrm{~nm}$. All retention times $\left(t_{\mathrm{R}}\right)$ are quoted in minutes. All screening compounds were of $>95 \%$ purity unless specified in the individual monologue. All NMR experiments were performed in $\mathrm{CDCl}_{3}$ to permit comparison of the spectra of the various analogues. Experiments were performed in acetone- $d_{6}$, DMSO- $d_{6}$, or $\mathrm{MeOH}-d_{4}$ if selected analogues lacked solubility in $\mathrm{CDCl}_{3}$.

General Synthetic Procedures. General Procedure A for the Gewald Synthesis of 2-Amino-3-Carbethoxy Thiophenes 5, 10a-c. To a stirred solution of ethyl cyanoacetate (1 equiv.) in absolute ethanol was added sulfur powder ( 1 equiv.), followed by the aldehyde or ketone (1 equiv) at r.t. under $\mathrm{N}_{2}$ and the resulting mixture cooled to $0-5{ }^{\circ} \mathrm{C}$. To this was added diethylamine (1 equiv.) and the reaction mixture warmed to r.t. and subsequently stirred at $50-55^{\circ} \mathrm{C}$ for $5 \mathrm{~h}$. The reaction was concentrated under reduced pressure and the residue was chromatographed on silica eluting with petroleum ether/EtOAc (10:1) to give the desired compound as a solid or oil which can be recrystallised from an appropriate solvent as indicated.

General Synthetic Procedures. General Procedure B for the Gewald Synthesis of 2-Amino-3-Carbethoxy Thiophenes 5, 10d-i. An equimolar mixture of powdered sulfur and morpholine was stirred until total dissolution of the sulfur. After, the ethyl cyanoacetate (1 equiv.) and the aldehyde or ketone (1 equiv.) were 
added to the reactional mixture, which was stirred at room temperature for $\sim 18 \mathrm{~h}$. After completion of the reaction, as monitored by TLC, the crude product was chromatographed on silica with an appropriate eluent as indictaed to afford the desired compound which could be recrystallised from an appropriate solvent as indicated.

General Procedure $C$ for the Preparation of 6, 11a-j, 31, 36a-c, 37b-c, 41. The required amino ethyl ester thiophene ( 1 equiv) and appropariate nitrile (1.2 equiv) were taken up in 1,4-dioxane, heated to $50{ }^{\circ} \mathrm{C}$, and passed with dry $\mathrm{HCl}$ gas (Kipp's apparatus) until the starting material was absent in 3-24 h or a precipitate formed. The reaction mixture was filtered directly and the solid washed with $n$-hexane to obtain the desired compound. Depending on purity, the solid may be recrystallised from an appropriate solvent or reacted without further purification. Alternatively, the reaction mixture can be concentrated under reduced pressure and the residue chromatographed with an appropriate eluent as indicated.

General Procedure D for the Preparation of 7, 12a-j, 37a. The required 2-chloro-thienopyrimidinone (1 equiv.) was taken up in DMF. To this solution/suspension was added morpholine (2.5 equiv) and the resulting solution/suspension was stirred at $100{ }^{\circ} \mathrm{C}$ for $2-3 \mathrm{~h}$. The reaction mixture was then cooled to room temperature or $\sim 4{ }^{\circ} \mathrm{C}$ to induce crystallisation of product. Any crystals were collected using vacuum filtration, washed with cold $i$-PrOH and again recrystallised from $i-\mathrm{PrOH}$. In the case of present morpholinium hydrochloride, the solids were dissolved in $\mathrm{CHCl}_{3}$, washed with $5 \% \mathrm{NaHCO}_{3}$ solution, water, brine, and the organic extracts concentrated in vасио. If no crystallisation from reaction mixture was evident, the residue can be chromatographed on silica using 1\% Et 3 N/EtOAc unless otherwise indicated.

General Procedure E for the Preparation of Chloropyrimidines 8, 13a-j, 22, 25, 38a-c, 42, 46. The required thienopyrimidinone (1 equiv.) was taken up in toluene. To this solution/suspension was added phosphorous oxychloride (4 equiv), $N, N$-dimethylformamide (cat.) and the solution/suspension was stirred at $100{ }^{\circ} \mathrm{C}$. After TLC has indicated complete consumption of starting material, the reaction mixture was slowly introduced into a stirred suspension of ice water and the $\mathrm{pH}$ adjusted to $\sim 12$ with $6 \mathrm{M} \mathrm{NaOH}$. The aqueous phase was extracted with EtOAc and the combined organic extracts dried over anhydrous sodium sulfate and concented in vacuo. The resulting oil/solid, depending on purity, can be reacted without further purification, or further purified using column chromatography (1:99 $\mathrm{Et}_{3} \mathrm{~N}$ :EtOAc) or recrystallised as indicated. 
General Procedure F for the Synthesis of 1, 14a-j, 16a-c, 18-20, 23a-b, 33a-b, 39a-c, 40, 43a-b, 44, 47a-b. In a suitable microwave reaction vessel the required chloropyrimidine (1equiv.) was taken up in $i$-PrOH. To this was added the required amine (1.1 equiv) and the mixture irradiated under stirring at $120{ }^{\circ} \mathrm{C}$ for $1-2 \mathrm{~h}$. Upon completion of the reaction, the mixture can purified using silica gel chromatography to afford the compound. Similarly, any precipitate can be collected under vacuum and washed with cold $i$-PrOH to afford the desired compound.

\section{2-(Morpholinomethyl)- $N$-(3-(trifluoromethyl)phenyl)-5,6,7,8-tetrahydrobenzo[4,5]thieno[2,3-}

d]pyrimidin-4-amine (1). General procedure F. The residue was chromatographed on silica (1:99 $\left.\mathrm{MeOH} / \mathrm{CHCl}_{3}\right)$ which furnished the title compound as a white foam $(160 \mathrm{mg}, 70 \%)$. LCMS (m/z): $449.2[\mathrm{M}$ $+\mathrm{H}]^{+}$. HPLC: $t_{\mathrm{R}} 7.912 \mathrm{~min}$. HRMS $(m / z): \mathrm{C}_{23} \mathrm{H}_{23} \mathrm{~F}_{3} \mathrm{~N}_{3} \mathrm{OS}$ requires $449.1671[\mathrm{M}+\mathrm{H}]^{+}$; found $449.1661 .{ }^{1} \mathrm{H}$ NMR $\delta 8.17(\mathrm{~s}, 1 \mathrm{H}), 7.93(\mathrm{dd}, J=8.1,1.6 \mathrm{~Hz}, 1 \mathrm{H}), 7.48(\mathrm{t}, J=8.0 \mathrm{~Hz}, 1 \mathrm{H}), 7.34-7.31(\mathrm{~d}, J=7.7 \mathrm{~Hz}, 1 \mathrm{H})$, $7.26(\mathrm{~s}, 1 \mathrm{H}), 3.77(\mathrm{~s}, 2 \mathrm{H}), 3.09(\mathrm{t}, J=6.0 \mathrm{~Hz}, 2 \mathrm{H}), 2.87(\mathrm{t}, J=6.0 \mathrm{~Hz}, 2 \mathrm{H}), 2.58(\mathrm{~s}, 4 \mathrm{H}), 2.04-1.97(\mathrm{~m}), 1.98$ - $1.94(\mathrm{~m}, 2 \mathrm{H}), 1.66(\mathrm{dt}, J=11.2,5.6 \mathrm{~Hz}, 4 \mathrm{H}) .{ }^{13} \mathrm{C} \mathrm{NMR}\left(\mathrm{CDCl}_{3}\right) \delta 167.5,161.4,154.2,139.7,135.0,131.4$ $(\mathrm{q}, J=32.3 \mathrm{~Hz}), 129.5,124.2,124.1(\mathrm{q}, J=272.4 \mathrm{~Hz}), 123.2,119.7(\mathrm{q}, J=3.8 \mathrm{~Hz}), 117.1(\mathrm{q}, J=4.0 \mathrm{~Hz})$, $115.1,65.8,54.8,26.6,26.0,24.3,22.7,22.5$.

2-Amino-4,5,6,7-tetrahydrobenzo[b]thiophene-3-carboxylate ${ }^{33}$ (4). General Procedure A. The reaction mixture was kept for $30 \mathrm{~min}$ at $0{ }^{\circ} \mathrm{C}$ and formed crystals were collected under vacuum filtration, washed with chilled ethanol $(2 \times 50 \mathrm{~mL})$ and dried to give the title compound as bright yellow needles which were used as such for the next reaction without further purification $(2.83 \mathrm{~g}, 80 \%) . \mathrm{mp}: 110-114{ }^{\circ} \mathrm{C} .{ }^{1} \mathrm{H}$ NMR $\left(d_{6}\right.$-acetone) $\delta 6.88(\mathrm{~s}, 2 \mathrm{H}), 4.21(\mathrm{q}, J=7.1 \mathrm{~Hz}, 2 \mathrm{H}), 2.72-2.60(\mathrm{~m}, 2 \mathrm{H}), 2.45(\mathrm{~m}, 2 \mathrm{H}), 1.81-1.63(\mathrm{~m}, 4 \mathrm{H}), 1.29(\mathrm{t}, J=$ $7.1 \mathrm{~Hz}, 3 \mathrm{H}) .{ }^{13} \mathrm{C}$ NMR ( $d_{6}$-acetone) $\delta 165.6,162.9,131.9,116.2,104.1,58.7,26.8,24.1,23.1,22.7,13.9$. LCMS (m/z): $226.2[\mathrm{M}+\mathrm{H}]^{+}$. HPLC: $t_{\mathrm{R}} 8.389 \mathrm{~min}$. HRMS $(\mathrm{m} / \mathrm{z}): \mathrm{C}_{11} \mathrm{H}_{15} \mathrm{NO}_{2} \mathrm{~S}$ requires $225.0818[\mathrm{M}+\mathrm{H}]^{+}$; found 225.0818 .

\section{2-(Chloromethyl)-5,6,7,8-tetrahydrobenzo[4,5]thieno[2,3- $d]$ pyrimidin-4(3H)-one $\quad(6) .{ }^{16}$ General}

procedure C. The reaction mixture was filtered directly and the solid washed with $n$-hexane to obtain the desired compound as a beige solid $(4.21 \mathrm{~g}, 93 \%)$. LCMS $(\mathrm{m} / \mathrm{z}): 255.1[\mathrm{M}+\mathrm{H}]^{+}$. HPLC: $t_{\mathrm{R}} 6.858 \mathrm{~min}$. HRMS $(m / z): \mathrm{C}_{11} \mathrm{H}_{11} \mathrm{ClN}_{2} \mathrm{OS}$ requires $255.0354[\mathrm{M}+\mathrm{H}]^{+}$; found 255.0353. ${ }^{1} \mathrm{H}$ NMR $\left(d_{6}\right.$-DMSO) $\delta 12.72(\mathrm{~s}, 1 \mathrm{H})$, 
$4.56(\mathrm{~s}, 2 \mathrm{H}), 2.85(\mathrm{t}, J=5.8 \mathrm{~Hz}, 2 \mathrm{H}), 2.73(\mathrm{t}, J=5.8 \mathrm{~Hz}, 2 \mathrm{H}), 1.76(\mathrm{ddd}, J=7.5,6.8,4.4 \mathrm{~Hz}, 4 \mathrm{H}) .{ }^{13} \mathrm{C}$ NMR $\left(d_{6}\right.$-DMSO) $\delta 162.4,158.6,152.4,133.7,131.3,122.1,43.0,25.6,24.9,22.8,22.1$.

2-(Morpholinomethyl)-5,6,7,8-tetrahydrobenzo[4,5]thieno[2,3- $d]$ pyrimidin-4(3H)-one $\quad(7)$ General procedure D. Reaction cooled and crystals collected under vacuum filtration to obtain the desired compound as a white crystalline solid $(2.59 \mathrm{~g}, 70 \%)$. LCMS $(\mathrm{m} / \mathrm{z}): 306.1[\mathrm{M}+\mathrm{H}]^{+}$. HPLC: $t_{\mathrm{R}} 4.334 \mathrm{~min} .{ }^{1} \mathrm{H}$ NMR $\left(\mathrm{CDCl}_{3}\right) \delta 10.14(\mathrm{~s}, 1 \mathrm{H}), 3.80-3.73(\mathrm{~m}, 4 \mathrm{H}), 3.57(\mathrm{~s}, 2 \mathrm{H}), 3.09-3.02(\mathrm{~m}, 2 \mathrm{H}), 2.94(\mathrm{t}, J=7.3 \mathrm{~Hz}, 2 \mathrm{H}), 2.63$ $-2.57(\mathrm{~m}, 4 \mathrm{H}), 2.51-2.40(\mathrm{~m}, 2 \mathrm{H}) .{ }^{13} \mathrm{C} \mathrm{NMR}\left(\mathrm{CDCl}_{3}\right) \delta 168.6,158.2,152.2,140.1,138.7,119.5,66.7,60.6$, 53.6, 32.2, 29.5, 28.9, 27.

\section{4-((4-Chloro-5,6,7,8-tetrahydrobenzo[4,5]thieno[2,3-d]pyrimidin-2-yl)methyl)morpholine (8).}

General Procedure E. The residue was chromatographed on silica (1:99 Et 3 N:EtOAc) to afford the compound as a brown oil $(270 \mathrm{mg}, 67 \%)$. LCMS $(\mathrm{m} / \mathrm{z}): 324.1[\mathrm{M}+\mathrm{H}]^{+}$. HPLC: $t_{\mathrm{R}} 5.112 \mathrm{~min} .{ }^{1} \mathrm{H}$ NMR $\left(\mathrm{CDCl}_{3}\right) \delta 3.80$ (s, 2H), $3.06(\mathrm{t}, J=4.2 \mathrm{~Hz}, 2 \mathrm{H}), 2.84(\mathrm{t}, J=4.2 \mathrm{~Hz}, 2 \mathrm{H}), 2.52-2.49(\mathrm{~m}, 4 \mathrm{H}), 1.93-1.86(\mathrm{~m}, 2 \mathrm{H}), 1.67-1.57$ $(\mathrm{m}, 4 \mathrm{H}), 1.49-1.36(\mathrm{~m}, 2 \mathrm{H}) .{ }^{13} \mathrm{C} \mathrm{NMR}\left(\mathrm{CDCl}_{3}\right) \delta 169.4,161.4,152.9,138.9,126.9,126.9,65.2,54.7,26.3$, $26.0,25.7,24.1,22.2$.

Ethyl 2-amino-5,6-dihydro-4H-cyclopenta[b]thiophene-3-carboxylate (10a). ${ }^{15}$ General Procedure A. The reaction was concentrated under reduced pressure and the residue eluted through a silica gel column (10:1 petroleum ether:EtOAc) to afford the compound as a yellow solid which later turned a dark brown (1.18 $\mathrm{g}$, 37\%). General procedure B. The reaction was concentrated under reduced pressure and the residue eluted through a silica gel column (10:1 petroleum ether/EtOAc) to afford the compound as a yellow solid which later turned brown $(2.21 \mathrm{~g}, 44 \%)$. LCMS $(\mathrm{m} / \mathrm{z}): 212.1[\mathrm{M}+\mathrm{H}]^{+}$. HPLC: $t_{\mathrm{R}} 8.102 \mathrm{~min} .{ }^{1} \mathrm{H} \mathrm{NMR}\left(\mathrm{CDCl}_{3}\right) \delta$ $5.85(\mathrm{~s}, 2 \mathrm{H}), 4.24(\mathrm{q}, J=7.1 \mathrm{~Hz}, 2 \mathrm{H}), 2.82(\mathrm{ddd}, J=7.9,3.9,1.9 \mathrm{~Hz}, 2 \mathrm{H}), 2.74-2.68(\mathrm{~m}, 2 \mathrm{H}), 2.35-2.26$ $(\mathrm{m}, 2 \mathrm{H}), 1.32(\mathrm{t}, J=7.1 \mathrm{~Hz}, 1 \mathrm{H}) .{ }^{13} \mathrm{C} \mathrm{NMR}\left(\mathrm{CDCl}_{3}\right) \delta 166.4,165.9,142.8,121.4,103.0,59.5,30.9,29.0$, 27.4, 14.6.

Ethyl 2-amino-5,6,7,8-tetrahydro-4H-cyclohepta[b]thiophene-3-carboxylate (10b). General procedure A. The reaction was concentrated under reduced pressure and the residue chromatographed on silica (10:1 petroleum ether:EtOAc). The resulting residue was recrystallised from $\mathrm{CHCl}_{3} /$ petroleum ether to afford the desired compound as yellow crystals $(1.55 \mathrm{~g}, 48 \%)$. LCMS $(\mathrm{m} / \mathrm{z}): 240.2[\mathrm{M}+\mathrm{H}]^{+}$. HPLC: $t_{\mathrm{R}} 8.791 \mathrm{~min}$. 
General procedure B. The crude product was purified by silica gel column chromatography (10:1 petroleum ether:EtOAc) to afford the title compound as a yellow solid $(3.87 \mathrm{~g}, 72 \%) .{ }^{1} \mathrm{H} \mathrm{NMR}\left(\mathrm{CDCl}_{3} \delta 5.76(\mathrm{~s}, 2 \mathrm{H})\right.$, $4.28(\mathrm{q}, J=7.1 \mathrm{~Hz}, 2 \mathrm{H}), 3.00-2.94(\mathrm{~m}, 2 \mathrm{H}), 2.60-2.54(\mathrm{~m}, 2 \mathrm{H}), 1.85-1.76(\mathrm{~m}, 2 \mathrm{H}), 1.68-1.56(\mathrm{~m}, 4 \mathrm{H})$, $1.34(\mathrm{t}, J=7.1 \mathrm{~Hz}, 3 \mathrm{H}) .{ }^{13} \mathrm{C} \mathrm{NMR}\left(\mathrm{CDCl}_{3}\right) \delta 166.1,159.9,138.0,121.4,107.6,59.6,32.2,28.7,28.7,27.9$, 27.0, 14.5.

Ethyl 2-amino-4,5,6,7,8,9-hexahydrocycloocta[b]thiophene-3-carboxylate (10c). General procedure A. The solvent was removed under reduced pressure and the residue eluted through a silica gel column (10:1 petroleum ether/EtOAc). The product was recrystallised from $\mathrm{CHCl}_{3} /$ petroleum ether to give the desired compound as yellow crystals $(1.32 \mathrm{~g}, 37 \%)$. LCMS $(\mathrm{m} / \mathrm{z}): 254.2[\mathrm{M}+\mathrm{H}]^{+}$. HPLC: $t_{\mathrm{R}} 9.405$ min. General procedure B. After completion of the reaction ( $24 \mathrm{~h})$, as monitored by TLC, the mixture was concentrated under reduced pressure and the crude product was purified by silica gel column chromatography (10:1 petroleum ether:EtOAc) to afford the title compound as a yellow solid $(2.63 \mathrm{~g}, 65 \%) .{ }^{1} \mathrm{H} \mathrm{NMR}\left(\mathrm{CDCl}_{3}\right) \delta 5.94$ $(\mathrm{s}, 1 \mathrm{H}), 4.27(\mathrm{q}, J=7.1 \mathrm{~Hz}, 2 \mathrm{H}), 2.85-2.77(\mathrm{~m}, 2 \mathrm{H}), 2.61-2.57(\mathrm{~m}, 2 \mathrm{H}), 2.43-2.36(\mathrm{~m}, 1 \mathrm{H}), 1.91-1.82$ $(\mathrm{m}, 1 \mathrm{H}), 1.65-1.59(\mathrm{~m}, 2 \mathrm{H}), 1.58-1.52(\mathrm{~m}, 2 \mathrm{H}), 1.49-1.41(\mathrm{~m}, 2 \mathrm{H}), 1.37-1.26(\mathrm{~m}, 3 \mathrm{H}) .{ }^{13} \mathrm{C} \mathrm{NMR}\left(\mathrm{CDCl}_{3}\right)$ $\delta 166.1,161.5,134.9,120.2,106.2,59.5,32.1,29.9,26.8,26.6,25.9,25.7,14.4$.

Ethyl 2-amino-5-phenylthiophene-3-carboxylate (10d). General procedure B. After completion of the reaction, as monitored by TLC, the mixture was concentrated under reduced pressure and the crude product was purified by silica gel column chromatography (10:1 petroleum ether:EtOAc). This resulting brown solid was recrystallised from $i$-PrOH to afford the title compound as dark orange needles $(6.30 \mathrm{~g}, 54 \%)$. LCMS $(m / z): 248.1[\mathrm{M}+\mathrm{H}]^{+} . \mathrm{HPLC}: t_{\mathrm{R}} 7.946 \mathrm{~min} .{ }^{1} \mathrm{H} \mathrm{NMR}\left(\mathrm{CDCl}_{3}\right) \delta 7.47-7.42(\mathrm{~m}, 2 \mathrm{H}), 7.36-7.30(\mathrm{~m}, 2 \mathrm{H})$, $7.25(\mathrm{~s}, 1 \mathrm{H}), 7.23-7.18(\mathrm{~m}, 1 \mathrm{H}), 6.02(\mathrm{~s}, 2 \mathrm{H}) 4.31(\mathrm{q}, J=7.1 \mathrm{~Hz}, 2 \mathrm{H}), 1.37(\mathrm{t}, J=7.1 \mathrm{~Hz}, 3 \mathrm{H}) .{ }^{13} \mathrm{C}$ NMR $\left(\mathrm{CDCl}_{3}\right) \delta 165.5,162.1,134.1,128.9,126.7,124.9,124.8,121.3,108.1,60.0,14.6$.

Ethyl 2-amino-4-phenylthiophene-3-carboxylate (10e). General procedure B. The reaction mixture was concentrated under reduced pressure and the crude product was purified by silica gel column chromatography (10:1 petroleum ether:EtOAc). This resulting yellow solid was recrystallised from $i$-PrOH to afford the title compound as yellow crystals $(4.88 \mathrm{~g}, 49 \%)$. LCMS $(\mathrm{m} / \mathrm{z}): 248.1[\mathrm{M}+\mathrm{H}]^{+}$. HPLC: $t_{\mathrm{R}} 7.379 \mathrm{~min} .{ }^{1} \mathrm{H}$ NMR 
$\left(\mathrm{CDCl}_{3}\right) \delta 7.33-7.28(\mathrm{~m}, 5 \mathrm{H}), 6.10(\mathrm{~s}, 2 \mathrm{H}), 6.07(\mathrm{~s}, 2 \mathrm{H}), 4.04(\mathrm{q}, J=7.1 \mathrm{~Hz}, 2 \mathrm{H}), 0.93(\mathrm{t}, J=7.1 \mathrm{~Hz}, 3 \mathrm{H})$.

${ }^{13} \mathrm{C} \mathrm{NMR}\left(\mathrm{CDCl}_{3} \delta 165.8,163.9,141.7,138.6,129.0,127.3,126.9,105.6,59.5,13.7\right.$.

Ethyl 2-amino-5-benzylthiophene-3-carboxylate (10f). General procedure B. After completion of the reaction, as monitored by TLC, the mixture was concentrated under reduced pressure and the crude product chromatographed on silica (10:1 petroleum ether:EtOAc) to afford the title compound as a yellow oil (2.71 g, 35\%). LCMS $(\mathrm{m} / \mathrm{z}): 262.1[\mathrm{M}+\mathrm{H}]^{+}$. HPLC: $t_{\mathrm{R}} 8.633 \mathrm{~min} .{ }^{1} \mathrm{H}$ NMR $\left(\mathrm{CDCl}_{3} \delta 7.30-7.26(\mathrm{~m}, 2 \mathrm{H}), 7.23-7.18\right.$ $(\mathrm{m}, 3 \mathrm{H}), 6.69(\mathrm{t}, J=1.0 \mathrm{~Hz}, 1 \mathrm{H}), 5.83(\mathrm{~s}, 2 \mathrm{H}), 4.22(\mathrm{q}, J=7.1 \mathrm{~Hz}, 2 \mathrm{H}), 3.87(\mathrm{~s}, 2 \mathrm{H}), 1.30(\mathrm{t}, J=7.1 \mathrm{~Hz}, 1 \mathrm{H})$. ${ }^{13} \mathrm{C} \mathrm{NMR}\left(\mathrm{CDCl}_{3}\right) \delta 165.4,162.3,139.9,128.5,128.49,126.5,125.1,122.8,106.1,59.6,36.0,14.5$.

Ethyl 2-amino-4-cyclohexylthiophene-3-carboxylate (10g). General procedure B. After completion of the reaction, as monitored by TLC, the reaction mixture was concentrated under reduced pressure and the crude product purified by silica gel column chromatography (10:1 petroleum ether:EtOAc). Collected fractions were concentrated under reduced pressure and placed in the freezer for $2 \mathrm{~h}$. Formed solids were collected under vacuum and washed with petroleum ether to afford the compound as clear crystals $(3.56 \mathrm{~g}, 38 \%)$. LCMS $(\mathrm{m} / \mathrm{z})$ : $254.2[\mathrm{M}+\mathrm{H}]^{+} . \mathrm{HPLC}: t_{\mathrm{R}} 8.936 \mathrm{~min} .{ }^{1} \mathrm{H} \mathrm{NMR}\left(\mathrm{CDCl}_{3}\right) \delta 6.06(\mathrm{~s}, 2 \mathrm{H}), 5.85(\mathrm{~s}, 1 \mathrm{H}), 4.29(\mathrm{q}, J=7.1 \mathrm{~Hz}, 2 \mathrm{H})$, 3.03 (tt, $J=11.4,2.5 \mathrm{~Hz}, 1 \mathrm{H}), 1.97(\mathrm{~d}, J=12.0 \mathrm{~Hz}, 2 \mathrm{H}), 1.80(\mathrm{~d}, J=12.6 \mathrm{~Hz}, 2 \mathrm{H}), 1.73(\mathrm{~d}, J=12.5 \mathrm{~Hz}, 1 \mathrm{H})$, $1.37(\mathrm{t}, J=7.2 \mathrm{~Hz}, 5 \mathrm{H}), 1.28-1.15(\mathrm{~m}, 3 \mathrm{H}) .{ }^{13} \mathrm{C} \mathrm{NMR}\left(\mathrm{CDCl}_{3}\right) \delta 166.2,164.5,147.4,100.6,59.7,39.4,34.1$, 27.1, 26.6, 14.1.

Ethyl 2-amino-4,5-dimethylthiophene-3-carboxylate (10h). General procedure B. After completion of the reaction, as monitored by TLC, the mixture was concentrated under reduced pressure and the crude product was purified by silica gel column chromatography (10:1 petroleum ether:EtOAc) to afford the title compound as a pale yellow solid which was recrystallised from $i$-PrOH $(3.41 \mathrm{~g}, 38 \%)$. LCMS $(\mathrm{m} / \mathrm{z}): 200.1[\mathrm{M}+\mathrm{H}]^{+}$. HPLC: $t_{\mathrm{R}} 7.265 \mathrm{~min} .{ }^{1} \mathrm{H}$ NMR $\left(\mathrm{CDCl}_{3}\right) \delta 5.90(\mathrm{~s}, 2 \mathrm{H}), 4.27(\mathrm{q}, J=7.1 \mathrm{~Hz}, 2 \mathrm{H}), 2.16(\mathrm{~d}, J=0.7 \mathrm{~Hz}, 3 \mathrm{H}), 2.15$ $(\mathrm{d}, J=0.7 \mathrm{~Hz}, 2 \mathrm{H}), 1.34(\mathrm{t}, J=7.1 \mathrm{~Hz}, 3 \mathrm{H}) .{ }^{13} \mathrm{C} \mathrm{NMR}\left(\mathrm{CDCl}_{3}\right) \delta 166.2,161.0,130.4,113.9,107.0,59.7,14.9$, 14.5, 12.4 .

Ethyl 2-amino-5-cyclohexylthiophene-3-carboxylate (10i). General procedure B. After completion of the reaction, as monitored by TLC, the mixture was concentrated under reduced pressure and the crude product was chromatographed on silica (10:1 petroleum ether:EtOAc) to afford the title compound as a gold oil (3.05 
g, 73\%). LCMS $(m / z): 254.2[\mathrm{M}+\mathrm{H}]^{+}$. HPLC: $t_{\mathrm{R}} 8.918 \mathrm{~min} .{ }^{1} \mathrm{H} \mathrm{NMR}\left(\mathrm{CDCl}_{3}\right) \delta 6.62(\mathrm{~d}, J=1.1 \mathrm{~Hz}, 1 \mathrm{H})$, $5.79(\mathrm{~s}, 2 \mathrm{H}), 4.25(\mathrm{q}, J=7.1 \mathrm{~Hz}, 2 \mathrm{H}), 2.57-2.48(\mathrm{~m}, 1 \mathrm{H}), 2.00-1.91(\mathrm{~m}, 2 \mathrm{H}), 1.82-1.76(\mathrm{~m}, 2 \mathrm{H}), 1.72-$ $1.65(\mathrm{~m}, 1 \mathrm{H}), 1.36-1.29(\mathrm{~m}, 7 \mathrm{H}), 1.23-1.13(\mathrm{~m}, 1 \mathrm{H}) .{ }^{13} \mathrm{C} \mathrm{NMR}\left(\mathrm{CDCl}_{3}\right) \delta 165.6,160.9,133.3,119.1,106.2$, 59.6, 39.0, 34.9, 26.4, 26.0, 14.6.

Ethyl 2-aminothiophene-3-carboxylate (10j). ${ }^{\mathbf{3 4}}$ Triethylamine $(7.34 \mathrm{~mL}, 52.6 \mathrm{mmol})$ was added dropwise over $10 \mathrm{~min}$ to a mixture of 2,5-dihydroxy-1,4-dithiane ( $8.09 \mathrm{~g}, 52.6 \mathrm{mmol})$, ethyl cyanoacetate (11.2 mL, 105 mmol), and dimethylformamide (40 mL). The mixture was stirred for at $45^{\circ} \mathrm{C}$ for 30 min, diluted with $0.4 \mathrm{M}$ acetic acid and extracted with ether. The ethereal layer was dried over sodium sulphate. The residue was eluted through a silica gel column (10:1 petroleum ether:EtOAc) and the resulting fractions collected, concentrated under reduced pressure and cooled at $4{ }^{\circ} \mathrm{C}$ to afford the compound as a light yellow crystalline solid (5.00 g, $55 \%) . \operatorname{LCMS}(\mathrm{m} / \mathrm{z}): 172.1[\mathrm{M}+\mathrm{H}]^{+}$. HPLC: $t_{\mathrm{R}} 6.123 \mathrm{~min} .{ }^{1} \mathrm{H} \mathrm{NMR}\left(\mathrm{CDCl}_{3}\right) \delta 6.98(\mathrm{~d}, J=5.8 \mathrm{~Hz}, 1 \mathrm{H}), 6.18$ $(\mathrm{d}, J=5.8 \mathrm{~Hz}, 1 \mathrm{H}), 4.27(\mathrm{q}, J=7.1 \mathrm{~Hz}, 2 \mathrm{H}), 1.34(\mathrm{t}, J=7.1 \mathrm{~Hz}, 3 \mathrm{H}) .{ }^{13} \mathrm{C} \mathrm{NMR}\left(\mathrm{CDCl}_{3}\right) \delta 165.5,162.7,126.6$, 107.2, 106.9, 59.8, 14.6.

2-(Chloromethyl)-3,5,6,7-tetrahydro-4H-cyclopenta[4,5]thieno[2,3- $d]$ pyrimidin-4-one (11a). General procedure $\mathrm{C}$. The precipitate was collected and washed with cold 1,4-dioxane to afford the compound as a beige solid (2.56 g, 70\%.) LCMS ( $m / z): 292.1[\mathrm{M}+\mathrm{H}]^{+}$. HPLC: $t_{\mathrm{R}} 4.216 \mathrm{~min} .{ }^{1} \mathrm{H}$ NMR $\left(d_{6}-\mathrm{DMSO}\right) \delta 12.72$ (s, 1H), $4.54(\mathrm{~s}, 2 \mathrm{H}), 2.97-2.85(\mathrm{~m}, 4 \mathrm{H}), 2.37(\mathrm{p}, J=7.2 \mathrm{~Hz}, 2 \mathrm{H}) .{ }^{13} \mathrm{C} \mathrm{NMR}\left(d_{6}-\mathrm{DMSO}\right) \delta 167.2,157.9$, $151.7,139.7,138.7,119.3,42.7,29.1,28.6,27.5$.

2-(Chloromethyl)-3,5,6,7,8,9-hexahydro-4H-cyclohepta[4,5]thieno[2,3- $d]$ pyrimidin-4-one

(11b).

General procedure $\mathrm{C}$. The precipitate was collected and washed with cold 1,4-dioxane to afford the compound as a white powder $(5.00 \mathrm{~g}, 86 \%)$. LCMS $(\mathrm{m} / z): 269.1[\mathrm{M}+\mathrm{H}]^{+}$. HPLC: $t_{\mathrm{R}} 7.039 \mathrm{~min} .{ }^{1} \mathrm{H}$ NMR $\left(d_{6}-\mathrm{DMSO}\right) \delta$ $12.71(\mathrm{~s}, 1 \mathrm{H}), 4.57(\mathrm{~s}, 2 \mathrm{H}), 3.31-3.21(\mathrm{~m}, 2 \mathrm{H}), 2.86-2.79(\mathrm{~m}, 2 \mathrm{H}), 1.90-1.78(\mathrm{~m}, 2 \mathrm{H}), 1.69-1.49(\mathrm{~m}$, 4H). ${ }^{13} \mathrm{C}$ NMR ( $d_{6}$-DMSO) $\delta 160.4,158.7,151.7,137.6,136.6,122.2,42.6,32.0,29.1,27.3,27.1,26.9$.

\section{2-(Chloromethyl)-5,6,7,8,9,10-hexahydrocycloocta[4,5] thieno[2,3-d]pyrimidin-4(3H)-one (11c).}

General procedure $\mathrm{C}$. The precipitate was collected and washed with cold 1,4-dioxane to afford the compound as a white powder $(3.01 \mathrm{~g}, 78 \%)$. $\operatorname{LCMS}(\mathrm{m} / \mathrm{z}): 283.0[\mathrm{M}+\mathrm{H}]^{+}$. HPLC: $t_{\mathrm{R}} 7.426 \mathrm{~min} .{ }^{1} \mathrm{H}$ NMR $\left(d_{6}-\mathrm{DMSO}\right)$ $\delta 12.68(\mathrm{~s}, 1 \mathrm{H}), 4.55(\mathrm{~s}, 2 \mathrm{H}), 3.06-2.99(\mathrm{~m}, 2 \mathrm{H}), 2.90-2.82(\mathrm{~m}, 2 \mathrm{H}), 1.59(\mathrm{~s}, 4 \mathrm{H}), 1.41-1.36(\mathrm{~m}, 2 \mathrm{H}), 1.29$ 
- 1.19 (m, 2H). ${ }^{13} \mathrm{C}$ NMR (d6-DMSO) $\delta 161.6,158.2,151.7,136.1,133.8,121.6,42.6,31.5,29.8,26.1,25.4$, 25.2, 24.3.

2-(Chloromethyl)-5-phenylthieno[2,3- $d]$ pyrimidin-4(3H)-one (11d). General procedure $\mathrm{C}$. The bright orange suspension was filtered and the resulting solids were washed with cold 1,4-dioxane which afforded the desired compound as a yellow solid $(4.33 \mathrm{~g}, 82 \%)$. LCMS $(\mathrm{m} / \mathrm{z}): 277.1[\mathrm{M}+\mathrm{H}]^{+}$. HPLC: $t_{\mathrm{R}} 6.476 \mathrm{~min} .{ }^{1} \mathrm{H}$ NMR (d6-DMSO) $\delta 12.71(\mathrm{~s}, 1 \mathrm{H}), 7.55(\mathrm{~s}, 1 \mathrm{H}), 7.53(\mathrm{dd}, J=7.9,1.3 \mathrm{~Hz}, 2 \mathrm{H}), 7.41-7.37(\mathrm{~m}, 2 \mathrm{H}), 7.35(\mathrm{dd}$, $J=6.6,2.7 \mathrm{~Hz}, 1 \mathrm{H}) .{ }^{13} \mathrm{C}$ NMR $\left(d_{6}\right.$-DMSO) $\delta 165.3,157.8,153.1,138.5,135.1,129.4,127.6,127.5,121.8$, $119.9,42.5$.

2-(Chloromethyl)-6-phenylthieno[2,3- $d]$ pyrimidin-4(3H)-one (11e). General procedure C. The precipitate was collected from the crude reaction mixture and washed with hot $i-\mathrm{PrOH}$ to afford the compound as a white solid which was used without the need for further purification $(4.57 \mathrm{~g}, 64 \%)$. LCMS $(\mathrm{m} / \mathrm{z}): 277.1[\mathrm{M}+\mathrm{H}]^{+}$. HPLC: $t_{\mathrm{R}} 6.752 \mathrm{~min} .{ }^{1} \mathrm{H}$ NMR $\left(d_{6}\right.$-DMSO) $\delta 12.72(1 \mathrm{H}), 7.80(\mathrm{~s}, 1 \mathrm{H}), 7.78-7.73(\mathrm{~m}, 2 \mathrm{H}), 7.45(\mathrm{dd}, J=8.1$, $6.7 \mathrm{~Hz}, 2 \mathrm{H}), 7.38-7.34(\mathrm{~m}, 1 \mathrm{H}), 4.62(\mathrm{~s}, 2 \mathrm{H}) .{ }^{13} \mathrm{C}$ NMR $\left(d_{6}\right.$-DMSO) $\delta 162.9,157.6,153.2,140.4,132.6$, $129.3,128.8,125.8,125.1,117.3,42.6$.

6-Benzyl-2-(chloromethyl)thieno[2,3-d]pyrimidin-4(3H)-one (11f). General procedure C. The solvents were removed under reduced pressure and the residue was chromatographed on silica (40\% petroleum ether in EtOAc). The collected fractions were concentrated under reduced pressure and the resulting solid was recrystallised from $\mathrm{CHCl}_{3}$ affording the compound as white-yellow crystals ( $2.74 \mathrm{~g}$, quantitative yield). LCMS $(m / z): 291.1[\mathrm{M}+\mathrm{H}]^{+} . \mathrm{HPLC}: t_{\mathrm{R}} 6.680 \mathrm{~min} .{ }^{1} \mathrm{H}$ NMR $\left(d_{6}-\mathrm{DMSO}\right) \delta 7.62(\mathrm{~s}, 1 \mathrm{H}), 7.35-7.28(\mathrm{~m}, 4 \mathrm{H}), 7.25$ $(\mathrm{dd}, J=11.1,4.3 \mathrm{~Hz}, 1 \mathrm{H}), 7.16(\mathrm{~s}, 1 \mathrm{H}), 4.54(\mathrm{~s}, 2 \mathrm{H}), 4.20(\mathrm{~s}, 2 \mathrm{H}) .{ }^{13} \mathrm{C} \mathrm{NMR}\left(d_{6}-\mathrm{DMSO}\right) \delta 163.1,157.6,152.5$, $142.9,139.5,128.7,128.6,123.7,119.1,42.7,35.6$.

2-(Chloromethyl)-5-cyclohexylthieno[2,3-d]pyrimidin-4(3H)-one (11g). General procedure C. The precipitate was collected from the crude reaction mixture and washed with 1,4-dioxane. This afforded the desired compound as a yellow solid which was used without the need for further purification $(2.75 \mathrm{~g}, 70 \%)$. $\operatorname{LCMS}(\mathrm{m} / z): 283.1[\mathrm{M}+\mathrm{H}]^{+}$. HPLC: $t_{\mathrm{R}} 7.595 \mathrm{~min} .{ }^{1} \mathrm{H}$ NMR $\left(d_{6}\right.$-DMSO) $\delta 12.73(\mathrm{~s}, 1 \mathrm{H}), 7.21(\mathrm{~s}, 1 \mathrm{H}), 4.57$ (s, 2H), $3.26(\mathrm{t}, J=9.6 \mathrm{~Hz}, 1 \mathrm{H}), 1.95(\mathrm{~d}, J=9.8 \mathrm{~Hz}, 2 \mathrm{H}), 1.77(\mathrm{~d}, J=11.6 \mathrm{~Hz}, 2 \mathrm{H}), 1.70(\mathrm{~d}, J=12.9 \mathrm{~Hz}, 1 \mathrm{H})$, 
$1.41-1.28(\mathrm{~m}, 4 \mathrm{H}), 1.22(\mathrm{dt}, J=24.7,9.6 \mathrm{~Hz}, 1 \mathrm{H}) .{ }^{13} \mathrm{C}$ NMR $\left(d_{6}-\mathrm{DMSO}\right) \delta 164.6,158.3,152.6,144.8,120.9$, 116.6, 42.5, 37.9, 33.1, 26.3, 25.8 .

2-(Chloromethyl)-5,6-dimethylthieno[2,3- $d]$ pyrimidin-4(3H)-one (11h). General procedure C. The precipitate was collected from the crude reaction mixture, and washed with hot $\mathrm{CHCl}_{3}$ to afford the compound as a yellow solid $(3.38 \mathrm{~g}, 84 \%)$. LCMS $(\mathrm{m} / \mathrm{z}): 229.0[\mathrm{M}+\mathrm{H}]^{+}$. HPLC: $t_{\mathrm{R}} 5.717 \mathrm{~min} .{ }^{1} \mathrm{H}$ NMR $\left(d_{6}\right.$-DMSO) $\delta$ $12.69(\mathrm{~s}, 1 \mathrm{H}), 4.55(\mathrm{~s}, 2 \mathrm{H}), 2.36(\mathrm{~d}, J=0.8 \mathrm{~Hz}, 3 \mathrm{H}), 2.34(\mathrm{~d}, J=0.7 \mathrm{~Hz}, 1 \mathrm{H}) .{ }^{13} \mathrm{C} \mathrm{NMR}\left(d_{6}\right.$-DMSO) $\delta 161.2$, $158.4,151.9,130.4,128.8,122.4,42.6,12.7,12.7$.

2-(Chloromethyl)-6-cyclohexylthieno[2,3- $d]$ pyrimidin-4(3H)-one (11i). General procedure C. The precipitate was collected from the crude reaction under vacuum filtration and washed with cold 1,4-dioxane. The remaining filtrate was concentrated reduced under pressure and the resulting residue chromatographed on silica (40:60 EtOAc:petroleum ether) to afford the compound as a yellow solid (2.56 g, 64\%). LCMS $(\mathrm{m} / \mathrm{z})$ : $283.0[\mathrm{M}+\mathrm{H}]^{+} . \mathrm{HPLC}: t_{\mathrm{R}} 7.614 \mathrm{~min} .{ }^{1} \mathrm{H}$ NMR $\left(d_{6}\right.$-DMSO) $\delta 12.67(\mathrm{~s}, 1 \mathrm{H}), 7.09(\mathrm{~d}, J=0.5 \mathrm{~Hz}, 1 \mathrm{H}), 4.57(\mathrm{~s}$, 2H), $2.89-2.78(\mathrm{~m}, 1 \mathrm{H}), 1.97(\mathrm{~d}, J=8.5 \mathrm{~Hz}, 2 \mathrm{H}), 1.76(\mathrm{~d}, J=2.3 \mathrm{~Hz}, 2 \mathrm{H}), 1.65(\mathrm{~d}, J=12.5 \mathrm{~Hz}, 1 \mathrm{H}), 1.46-$ $1.28(\mathrm{~m}, 4 \mathrm{H}), 1.24-1.15(\mathrm{~m}, 1 \mathrm{H}) .{ }^{13} \mathrm{C} \mathrm{NMR}\left(d_{6}-\mathrm{DMSO}\right) \delta 161.9,157.7,152.3,149.8,123.6,116.1,42.7$, $38.9,34.5,25.7,25.3$.

2-(Chloromethyl)thieno[2,3- $d]$ pyrimidin-4(3H)-one $(\mathbf{1 1 j})$. General procedure $C$. The reaction mixture was concentrated under reduced pressure and the residue chromatographed on silica (50:50 petroleum ether:EtOAc) which afforded the compound as a pale white solid $(1.58 \mathrm{~g}, 21 \%)$. LCMS $(\mathrm{m} / \mathrm{z}): 201.0[\mathrm{M}+$ $\mathrm{H}]^{+}$. HPLC: $t_{\mathrm{R}} 4.394 \mathrm{~min} .{ }^{1} \mathrm{H}$ NMR $\left(d_{6}-\mathrm{DMSO}\right) \delta 7.62(\mathrm{~d}, J=5.8 \mathrm{~Hz}, 1 \mathrm{H}), 7.40(\mathrm{~d}, J=5.8 \mathrm{~Hz}, 1 \mathrm{H}), 4.58(\mathrm{~s}$, $2 \mathrm{H}) .{ }^{13} \mathrm{C}$ NMR $\left(d_{6}\right.$-DMSO) $\delta 163.8,157.9,152.8,124.8,123.6,121.6,42.7$.

2-(Morpholinomethyl)-3,5,6,7-tetrahydro-4H-cyclopenta[4,5]thieno[2,3- $d]$ pyrimidin-4-one (12a). General Procedure D. The residue was chromatographed on silica (1:99 Et $3 \mathrm{~N}$ :EtOAc) affording the compound as a beige solid (2.52 g, 86\%). LCMS (m/z): $292.1[\mathrm{M}+\mathrm{H}]^{+}$. HPLC: $t_{\mathrm{R}} 4.216 \mathrm{~min}$. HRMS $(\mathrm{m} / z): \mathrm{C}_{14} \mathrm{H}_{17} \mathrm{~N}_{3} \mathrm{O}_{2} \mathrm{~S}$ requires 292.112[M + H] $]^{+}$; found 292.114. ${ }^{1} \mathrm{H} \mathrm{NMR}\left(\mathrm{CDCl}_{3}\right) \delta 10.14(\mathrm{~s}, 1 \mathrm{H}), 3.80-3.73(\mathrm{~m}, 4 \mathrm{H}), 3.57(\mathrm{~s}$, 2H), $3.09-3.02(\mathrm{~m}, 2 \mathrm{H}), 2.94(\mathrm{t}, J=7.3 \mathrm{~Hz}, 2 \mathrm{H}), 2.63-2.57(\mathrm{~m}, 4 \mathrm{H}), 2.51-2.40(\mathrm{~m}, 2 \mathrm{H}) .{ }^{13} \mathrm{C} \mathrm{NMR}\left(\mathrm{CDCl}_{3}\right)$ $\delta 168.6,158.2,152.2,140.1,138.7,119.5,66.7,60.6,53.6,29.5,28.9,27$. 
General Procedure D. A precipitate was collected collected and recrystallised from $\mathrm{CHCl}_{3} / i$-PrOH affording the compound as a white fluffy solid $(3.29 \mathrm{~g}, 83 \%)$. LCMS $(\mathrm{m} / \mathrm{z}): 320.1[\mathrm{M}+\mathrm{H}]^{+}$. HPLC: $t_{\mathrm{R}} 5.186 \mathrm{~min}$. HRMS $(m / z): \mathrm{C}_{16} \mathrm{H}_{21} \mathrm{~N}_{3} \mathrm{O}_{2} \mathrm{~S}$ requires $320.1433[\mathrm{M}+\mathrm{H}]^{+}$; found 320.1427. ${ }^{1} \mathrm{H}$ NMR $\left(\mathrm{CDCl}_{3}\right) \delta 10.09(\mathrm{~s}, 1 \mathrm{H}), 3.83-$ $3.70(\mathrm{~m}, 4 \mathrm{H}), 3.55(\mathrm{~s}, 2 \mathrm{H}), 3.37-3.25(\mathrm{~m}, 2 \mathrm{H}), 2.88-2.78(\mathrm{~m}, 2 \mathrm{H}), 2.60\left(\mathrm{~s}, 4 \mathrm{H}^{\prime}\right), 1.89(\mathrm{ddd}, J=8.3,7.5,4.3$ $\mathrm{Hz}, 2 \mathrm{H}), 1.74-1.63(\mathrm{~m}, 4 \mathrm{H}) .{ }^{13} \mathrm{C} \mathrm{NMR}\left(\mathrm{CDCl}_{3}\right) \delta 161.8,158.9,137.8,137.2,130.1,122.8,66.8,60.7,53.6$, 32.6, 30.1, 28.1, 27.8, 27.4.

2-(Morpholinomethyl)-5,6,7,8,9,10-hexahydrocycloocta[4,5]thieno[2,3- $d]$ pyrimidin-4(3H)-one

(12c).

General Procedure D. A precipitate was collected and recrystallised from $\mathrm{CHCl}_{3} / i$-PrOH to afford the compound as a white fluffy solid $(1.75 \mathrm{~g}, 63 \%)$. LCMS $(\mathrm{m} / \mathrm{z}): 334.1[\mathrm{M}+\mathrm{H}]^{+}$. HPLC: $t_{\mathrm{R}} 5.489 \mathrm{~min}$. HRMS $(m / z): \mathrm{C}_{17} \mathrm{H}_{23} \mathrm{~N}_{3} \mathrm{O}_{2} \mathrm{~S}$ requires $334.1592[\mathrm{M}+\mathrm{H}]^{+}$; found 334.1584. ${ }^{1} \mathrm{H}$ NMR $\left(\mathrm{CDCl}_{3}\right) \delta 10.17(\mathrm{~s}, 1 \mathrm{H}), 3.81-$ $3.71(\mathrm{~m}, 4 \mathrm{H}), 3.54(\mathrm{~s}, 2 \mathrm{H}), 3.13-3.05(\mathrm{~m}, 2 \mathrm{H}), 2.90-2.81(\mathrm{~m}, 2 \mathrm{H}), 2.67-2.51(\mathrm{~m}, 4 \mathrm{H}), 1.78-1.61(\mathrm{~m}$, 4H), $1.45\left(\mathrm{dd}, J=9.9,4.7 \mathrm{~Hz}, 2 \mathrm{H}, 1.37-1.25(\mathrm{~m}, 2 \mathrm{H}) .{ }^{13} \mathrm{C} \mathrm{NMR}\left(\mathrm{CDCl}_{3}\right) \delta 163.1,158.6,152.4,136.3,134.4\right.$, $122.2,66.9,60.8,53.7,31.9,30.3,27.1,26.1,25.8,25.2$.

2-(Morpholinomethyl)-6-phenylthieno[2,3- $d]$ pyrimidin-4(3H)-one (12d). General Procedure D. Upon cooling of the reaction mixture, a precipitate formed which was collected under vacuum and washed with cold $i$-PrOH affording the compound as a white solid $(2.71 \mathrm{~g}, 91 \%)$. LCMS $(\mathrm{m} / \mathrm{z}): 328.1[\mathrm{M}+\mathrm{H}]^{+}$. HPLC: $t_{\mathrm{R}} 5.092$ $\min$. HRMS $(m / z): \mathrm{C}_{17} \mathrm{H}_{17} \mathrm{~N}_{3} \mathrm{O}_{2} \mathrm{~S}$ requires $328.1118[\mathrm{M}+\mathrm{H}]^{+}$; found 328.1114. ${ }^{1} \mathrm{H}$ NMR $\left(d_{6}-\mathrm{DMSO}\right) \delta 10.85$ (s, 1H), $7.78(\mathrm{~s}, 1 \mathrm{H}), 7.78-7.73(\mathrm{~m}, 2 \mathrm{H}), 7.46(\mathrm{dd}, J=8.2,6.8 \mathrm{~Hz}, 2 \mathrm{H}), 7.41-7.34(\mathrm{~m}, 2 \mathrm{H}), 3.64-3.55$ $(\mathrm{m}, 4 \mathrm{H}), 3.48(\mathrm{~s}, 2 \mathrm{H}), 2.50(\mathrm{dd}, J=6.1,3.0 \mathrm{~Hz}, 4 \mathrm{H}) .{ }^{13} \mathrm{C} \mathrm{NMR}\left(d_{6}\right.$-DMSO) $\delta 163.3,157.8,155.1,139.3$, $132.8,129.3,128.6,125.8,124.7,117.1,66.1,60.4,53.0$.

2-(Morpholinomethyl)-5-phenylthieno[2,3- $d]$ pyrimidin-4(3H)-one (12e). General Procedure D. A precipitate was collected under vacuum and recrystallised from $\mathrm{CHCl}_{3} / i$-PrOH to afford the desired compound as bright yellow crystals $(2.67 \mathrm{~g}, 83 \%)$. LCMS $(\mathrm{m} / z): 328.1[\mathrm{M}+\mathrm{H}]^{+}$. HPLC: $t_{\mathrm{R}} 4.853 \mathrm{~min}$. HRMS $(\mathrm{m} / z)$ : $\mathrm{C}_{17} \mathrm{H}_{17} \mathrm{~N}_{3} \mathrm{O}_{2} \mathrm{~S}$ requires $328.1123[\mathrm{M}+\mathrm{H}]^{+}$; found 328.1114. ${ }^{1} \mathrm{H} \mathrm{NMR}\left(\mathrm{CDCl}_{3}\right) \delta 10.61(\mathrm{~s}, 1 \mathrm{H}), 7.58-7.54$ $(\mathrm{m}, 2 \mathrm{H}), 7.44-7.35(\mathrm{~m}, 3 \mathrm{H}), 7.10(\mathrm{~s}, 1 \mathrm{H}), 3.71-3.66(\mathrm{~m}, 4 \mathrm{H}), 3.53(\mathrm{~s}, 2 \mathrm{H}), 2.56-2.50(\mathrm{~m}, 4 \mathrm{H}) .{ }^{13} \mathrm{C}$ NMR $\left(\mathrm{CDCl}_{3}\right) \delta 166.7,158.4,154.2,139.6,135.4,129.5,127.9,127.9,120.3,66.8,60.7,53.6$. 
6-Benzyl-2-(morpholinomethyl)thieno[2,3- $d]$ pyrimidin-4(3H)-one (12f). General Procedure D. The residue was recrystallised from $\mathrm{CHCl}_{3} / i-\mathrm{PrOH}$ to afford the compound as beige crystals $(2.47 \mathrm{~g}, 78 \%)$. LCMS $(m / z): 342.1[\mathrm{M}+\mathrm{H}]^{+}$. HPLC: $t_{\mathrm{R}} 5.208 \mathrm{~min}$. HRMS $(\mathrm{m} / z): \mathrm{C}_{18} \mathrm{H}_{19} \mathrm{~N}_{3} \mathrm{O}_{2} \mathrm{~S}$ requires $342.1278[\mathrm{M}+\mathrm{H}]^{+}$; found 342.1271. ${ }^{1} \mathrm{H} \mathrm{NMR}\left(\mathrm{CDCl}_{3}\right) \delta 10.09(\mathrm{~s}, 1 \mathrm{H}), 7.35-7.30(\mathrm{~m}, 4 \mathrm{H}), 7.26(\mathrm{dt}, J=5.0,1.4 \mathrm{~Hz}, 3 \mathrm{H}), 7.13(\mathrm{t}, J=$ $1.1 \mathrm{~Hz}, 1 \mathrm{H}), 4.15(\mathrm{~s}, 2 \mathrm{H}), 3.78-3.74(\mathrm{~m}, 4 \mathrm{H}), 3.55(\mathrm{~s}, 2 \mathrm{H}), 2.61-2.54(\mathrm{~m}, 4 \mathrm{H}) .{ }^{13} \mathrm{C} \mathrm{NMR}\left(\mathrm{CDCl}_{3}\right) \delta 164.8$, $157.8,153.2,142.4,138.8,128.9,128.8,127.1,123.9,119.2,66.8,60.7,53.7,36.9$.

5-Cyclohexyl-2-(morpholinomethyl)thieno[2,3- $d]$ pyrimidin-4(3H)-one (12g). General Procedure D. $i$ $\mathrm{PrOH}$ was introduced to a cooled reaction mixture and the resulting precipitate collected to afford the compound as bright yellow crystals $\left(1.56 \mathrm{~g}, 63 \%\right.$ yield). LCMS $(\mathrm{m} / \mathrm{z}): 334.1[\mathrm{M}+\mathrm{H}]^{+}$. HPLC: $t_{\mathrm{R}} 5.715 \mathrm{~min}$. $\operatorname{HRMS}(m / z): \mathrm{C}_{17} \mathrm{H}_{23} \mathrm{~N}_{3} \mathrm{O}_{2} \mathrm{~S}$ requires $334.1587[\mathrm{M}+\mathrm{H}]^{+}$; found 334.1584. ${ }^{1} \mathrm{H} \mathrm{NMR}\left(\mathrm{CDCl}_{3}\right) \delta 10.15(\mathrm{~s}, 1 \mathrm{H})$, $6.82(\mathrm{~s}, 1 \mathrm{H}), 3.79-3.72(\mathrm{~m}, 4 \mathrm{H}), 3.56(\mathrm{~s}, 2 \mathrm{H}), 3.35(\mathrm{tt}, J=11.6,2.8 \mathrm{~Hz}, 1 \mathrm{H}), 2.62-2.56(\mathrm{~m}, 4 \mathrm{H}), 2.05(\mathrm{~d}, J$ $=11.7 \mathrm{~Hz}, 2 \mathrm{H}), 1.86-1.71(\mathrm{~m}, 3 \mathrm{H}), 1.54-1.41(\mathrm{~m}, 2 \mathrm{H}), 1.33(\mathrm{tt}, J=7.3,3.5 \mathrm{~Hz}, 2 \mathrm{H}), 1.29-1.18(\mathrm{~m}, 1 \mathrm{H})$. ${ }^{13} \mathrm{C} \mathrm{NMR}\left(\mathrm{CDCl}_{3}\right) \delta 166.1,158.5,153.3,146.0,121.3,115.2,66.9,60.6,53.7,38.7,33.8,26.8,26.4$.

5,6-Dimethyl-2-(morpholinomethyl)thieno[2,3-d]pyrimidin-4(3H)-one (12h). General Procedure D. Upon cooling of the reaction mixture, a formed precipitate was collected and washed with petroleum ether to afford the desired compound as a bright yellow solid $(2.74 \mathrm{~g}, 88 \%)$. LCMS $(\mathrm{m} / \mathrm{z}): 280.2[\mathrm{M}+\mathrm{H}]^{+}$. HPLC: $t_{\mathrm{R}} 4.198$ $\min . \mathrm{HRMS}(\mathrm{m} / \mathrm{z}): \mathrm{C}_{13} \mathrm{H}_{17} \mathrm{~N}_{3} \mathrm{O}_{2} \mathrm{~S}$ requires $280.1119[\mathrm{M}+\mathrm{H}]^{+}$; found 280.1114. ${ }^{1} \mathrm{H} \mathrm{NMR}\left(\mathrm{CDCl}_{3}\right) \delta 10.13(\mathrm{~s}$, $1 \mathrm{H}), 3.79-3.71(\mathrm{~m}, 4 \mathrm{H}), 3.53(\mathrm{~s}, 2 \mathrm{H}), 2.63-2.56(\mathrm{~m}, 4 \mathrm{H}), 2.46(\mathrm{~d}, J=0.6 \mathrm{~Hz}, 3 \mathrm{H}), 2.37(\mathrm{~s}, 3 \mathrm{H}) .{ }^{13} \mathrm{C}$ NMR $\left(\mathrm{CDCl}_{3}\right) \delta 162.7,158.7,152.6,130.3,129.5,122.9,66.9,60.7,53.7,13.2,13.1$.

6-Cyclohexyl-2-(morpholinomethyl)thieno[2,3- $d]$ pyrimidin-4(3H)-one (12i). General Procedure D. The solids were filtered from the cooled reaction mixture and recrystallised from $i$-PrOH to afford the compound as white fluffy crystals $(2.57 \mathrm{~g}, 60 \%)$. LCMS $(\mathrm{m} / \mathrm{z}): 334.2[\mathrm{M}+\mathrm{H}]^{+}$. HPLC: $t_{\mathrm{R}} 5.603 \mathrm{~min}$. HRMS $(\mathrm{m} / \mathrm{z})$ : $\mathrm{C}_{17} \mathrm{H}_{23} \mathrm{~N}_{3} \mathrm{O}_{2} \mathrm{~S}$ requires $334.1593[\mathrm{M}+\mathrm{H}]^{+}$; found 334.1584. ${ }^{1} \mathrm{H} \mathrm{NMR}\left(\mathrm{CDCl}_{3}\right) \delta 10.17(\mathrm{~s}, 1 \mathrm{H}), 7.13(\mathrm{~d}, J=$ $1.0 \mathrm{~Hz}, 1 \mathrm{H}), 3.79-3.71(\mathrm{~m}, 4 \mathrm{H}), 3.55(\mathrm{~s}, 2 \mathrm{H}), 2.83-2.73(\mathrm{~m}, 1 \mathrm{H}), 2.61-2.53(\mathrm{~m}, 4 \mathrm{H}), 2.10-2.02(\mathrm{~m}, 2 \mathrm{H})$, $1.83(\mathrm{dd}, J=9.9,2.9 \mathrm{~Hz}, 2 \mathrm{H}), 1.73(\mathrm{ddd}, J=9.6,5.6,1.5 \mathrm{~Hz}, 1 \mathrm{H}), 1.50-1.32(\mathrm{~m}, 4 \mathrm{H}), 1.30-1.18(\mathrm{~m}, 1 \mathrm{H})$. ${ }^{13} \mathrm{C} \mathrm{NMR}\left(\mathrm{CDCl}_{3}\right) \delta 163.5,158.0,152.8,150.2,123.7,115.8,66.9,60.8,53.7,39.9,34.9,26.3,25.9$. 
2-(Morpholinomethyl)thieno[2,3-d]pyrimidin-4(3H)-one (12j). General Procedure D. The residue was chromatographed on silica (1:99 $\mathrm{Et}_{3} \mathrm{~N}$ :EtOAc) which afforded the compound as a gold solid $(1.10 \mathrm{~g}, 58 \%)$. LCMS $(m / z): 252.1[\mathrm{M}+\mathrm{H}]^{+}$. HPLC: $t_{\mathrm{R}} 3.009$ min. HRMS $(\mathrm{m} / z): \mathrm{C}_{11} \mathrm{H}_{13} \mathrm{~N}_{3} \mathrm{O}_{2} \mathrm{~S}$ requires $252.0803[\mathrm{M}+\mathrm{H}]^{+}$; found 252.0801. ${ }^{1} \mathrm{H} \mathrm{NMR}\left(\mathrm{CDCl}_{3}\right) \delta 10.28(\mathrm{~s}, 1 \mathrm{H}), 7.44(\mathrm{~d}, J=5.8 \mathrm{~Hz}, 1 \mathrm{H}), 7.21(\mathrm{~d}, J=5.8 \mathrm{~Hz}, 1 \mathrm{H}), 3.78-$ $3.73(\mathrm{~m}, 4 \mathrm{H}), 3.57(\mathrm{~s}, 2 \mathrm{H}), 2.63-2.55(\mathrm{~m}, 4 \mathrm{H}) .{ }^{13} \mathrm{C} \mathrm{NMR}\left(\mathrm{CDCl}_{3}\right) \delta 165.3,158.2,153.8,123.7,123.1,121.9$, $66.8,60.7,53.7$.

4-((4-Chloro-6,7-dihydro-5H-cyclopenta[4,5]thieno[2,3- $d]$ pyrimidin-2-yl)methyl)morpholine

(13a).

General Procedure E. The residue was chromatographed on silica (1:99 Et 3 N:EtOAc) to afford the compound as a brown oil $(270 \mathrm{mg}, 67 \%)$. LCMS $(\mathrm{m} / \mathrm{z}): 310.1[\mathrm{M}+\mathrm{H}]^{+}$. HPLC: $t_{\mathrm{R}} 5.230 \mathrm{~min} .{ }^{1} \mathrm{H}$ NMR $\left(\mathrm{CDCl}_{3}\right) \delta 3.85$ (s, 1H), $3.78-3.75(\mathrm{~m}, 2 \mathrm{H}), 3.17-3.11(\mathrm{~m}, 2 \mathrm{H}), 3.07-3.02(\mathrm{~m}, 2 \mathrm{H}), 2.63-2.56(\mathrm{~m}, 4 \mathrm{H}), 2.56-2.47(\mathrm{~m}$, 1H). ${ }^{13} \mathrm{C} \mathrm{NMR}\left(\mathrm{CDCl}_{3}\right) \delta 174.3,160.5,152.9,144.6,136.2,124.6,66.9,64.9,53.8,30.3,29.5,27.5$.

\section{4-((4-Chloro-6,7,8,9-tetrahydro-5H-cyclohepta[4,5]thieno[2,3- $d]$ pyrimidin-2-yl)methyl)morpholine}

(13b). General Procedure E. The residue was chromatographed on silica (1:99 Et 3 N:EtOAc) to afford the compound as a gold oil $(2.62 \mathrm{~g}, 70 \%)$. LCMS $(\mathrm{m} / \mathrm{z}): 338.1[\mathrm{M}+\mathrm{H}]^{+}$. HPLC: $t_{\mathrm{R}} 5.949 \mathrm{~min} .{ }^{1} \mathrm{H}$ NMR $\left(\mathrm{CDCl}_{3}\right)$ $\delta 3.61(\mathrm{~s}, 2 \mathrm{H}), 3.56-3.49(\mathrm{~m}, 2 \mathrm{H}), 3.14-3.03(\mathrm{~m}, 2 \mathrm{H}), 2.77-2.66(\mathrm{~m}, 2 \mathrm{H}), 2.42-2.34(\mathrm{~m}, 4 \mathrm{H}), 1.69(\mathrm{dd}$, $J=11.3,5.9 \mathrm{~Hz}, 2 \mathrm{H}), 1.51(\mathrm{ddd}, J=10.7,9.4,5.4 \mathrm{~Hz}, 4 \mathrm{H}) .{ }^{13} \mathrm{C} \mathrm{NMR}\left(\mathrm{CDCl}_{3}\right) \delta 167.8,159.4,152.5,143.1$, $131.7,126.7,66.3,64.1,53.3,31.4,29.6,27.6,26.5,26.0$.

4-((4-Chloro-5,6,7,8,9,10-hexahydrocycloocta[4,5]thieno[2,3-d]pyrimidin-2-yl)methyl)morpholine

(13c). General Procedure E. The residue was chromatographed on silica (1:99 $\mathrm{Et}_{3} \mathrm{~N}$ :EtOAc) to afford the compound as a gold oil $(1.91 \mathrm{~g}, 67 \%)$. $\operatorname{LCMS}(\mathrm{m} / z): 352.1[\mathrm{M}+\mathrm{H}]^{+}$. HPLC: $t_{\mathrm{R}} 6.259 \mathrm{~min} .{ }^{1} \mathrm{H} \mathrm{NMR}\left(\mathrm{CDCl}_{3}\right)$ $\delta 3.44(\mathrm{~s}, 2 \mathrm{H}), 3.40-3.25(\mathrm{~m}, 4 \mathrm{H}), 2.75-2.65(\mathrm{~m}, 2 \mathrm{H}), 2.61-2.48(\mathrm{~m}, 2 \mathrm{H}), 2.26-2.15(\mathrm{~m}, 4 \mathrm{H}), 1.45-1.24$ $(\mathrm{m}, 4 \mathrm{H}), 1.08(\mathrm{dd}, J=9.5,4.8 \mathrm{~Hz}, 2 \mathrm{H}), 0.91-0.84(\mathrm{~m}, 2 \mathrm{H}) .{ }^{13} \mathrm{C} \mathrm{NMR}\left(\mathrm{CDCl}_{3}\right) \delta 168.2,159.4,152.0,141.3$, $128.4,125.8,65.9,63.8,53.0,30.8,29.4,27.2,25.5,24.5,24.1$.

4-((4-Chloro-6-phenylthieno[2,3- $d]$ pyrimidin-2-yl)methyl)morpholine (13d). General Procedure E. The residue was recrystallised from $\mathrm{CHCl}_{3} /$ petroleum ether to afford the compound as pale white crystals $(2.45 \mathrm{~g}$, 90\%). LCMS $(\mathrm{m} / \mathrm{z}): 346.1[\mathrm{M}+\mathrm{H}]^{+}$. HPLC: $t_{\mathrm{R}} 6.418 \mathrm{~min} .{ }^{1} \mathrm{H}$ NMR $\left(d_{6}\right.$-DMSO) $\delta 8.08(\mathrm{~s}, 1 \mathrm{H}), 7.96(\mathrm{~d}, J=$ 
$6.9 \mathrm{~Hz}, 2 \mathrm{H}), 7.58-7.48(\mathrm{~m}, 3 \mathrm{H}), 4.67(\mathrm{~s}, 2 \mathrm{H}), 3.89(\mathrm{~s}, 4 \mathrm{H}), 3.60-3.26(\mathrm{~m}, 4 \mathrm{H}) .{ }^{13} \mathrm{C}$ NMR $\left(d_{6}-\mathrm{DMSO}\right) \delta$ $167.7,153.5,145.9,131.7,130.2,130.1,129.5,126.8,114.9,63.4,59.9,51.8$.

4-((4-Chloro-5-phenylthieno[2,3- $d]$ pyrimidin-2-yl)methyl)morpholine (13e). General Procedure E. The residue was chromatographed on silica (1:99 $\mathrm{Et}_{3} \mathrm{~N}$ :EtOAc) which afforded the compound as a gold solid 1.02 g, 96\%). LCMS (m/z): $346.1[\mathrm{M}+\mathrm{H}]^{+}$. HPLC: $t_{\mathrm{R}} 5.595 \mathrm{~min} .{ }^{1} \mathrm{H}$ NMR $\left(d_{6}\right.$-DMSO) $\delta 7.95(\mathrm{~s}, 1 \mathrm{H}), 7.68-7.29$ $(\mathrm{m}, 5 \mathrm{H}), 3.80(\mathrm{~s}, 2 \mathrm{H}), 3.63-3.53(\mathrm{~m}, 4 \mathrm{H}), 2.55-2.51(\mathrm{~m}, 4 \mathrm{H}) .{ }^{13} \mathrm{C}$ NMR $\left(d_{6}\right.$-DMSO) $\delta 169.72,161.43$, $153.8,134.9,134.7,130.0,128.2,127.8,127.5,124.7,66.2,63.7,53.1$.

4-((6-Benzyl-4-chlorothieno[2,3- $d]$ pyrimidin-2-yl)methyl)morpholine (13f). General Procedure E. The residue was recrystallised from $\mathrm{CHCl}_{3} / \mathrm{i}$-PrOH to afford the compound as pale yellow crystals $(1.55 \mathrm{~g}, 70 \%)$. $\operatorname{LCMS}(\mathrm{m} / z): 360.1[\mathrm{M}+\mathrm{H}]^{+}$. HPLC: $t_{\mathrm{R}} 6.261 \mathrm{~min} .{ }^{1} \mathrm{H}$ NMR $\left(d_{6}-\mathrm{DMSO}\right) \delta 7.34(\mathrm{~d}, J=4.4 \mathrm{~Hz}, 1 \mathrm{H}), 4.35(\mathrm{~s}$, 2H), $3.76(\mathrm{~s}, 2 \mathrm{H}), 3.60-3.50(\mathrm{~m}, 4 \mathrm{H}), 2.56-2.44(\mathrm{~m}, 4 \mathrm{H}) .{ }^{13} \mathrm{C}$ NMR $\left(d_{6}\right.$-DMSO) $\delta 168.5,152.4,148.2$, $138.7,128.8,128.7,127.9,126.9,116.8,114.9,67.1,65.9,52.9,36.1$.

4-((4-Chloro-5-cyclohexylthieno[2,3- $d]$ pyrimidin-2-yl)methyl)morpholine (13g). General Procedure E. The residue was chromatographed on silica (1:99 Et ${ }_{3} \mathrm{~N}$ :EtOAc) which afforded the compound as a gold oil (1.14 g, 69\%). LCMS (m/z): $352.1[\mathrm{M}+\mathrm{H}]^{+} . \mathrm{HPLC}: t_{\mathrm{R}} 6.418 \mathrm{~min} .{ }^{1} \mathrm{H} \mathrm{NMR}\left(\mathrm{CDCl}_{3}\right) \delta 7.21(\mathrm{~d}, J=0.7 \mathrm{~Hz}$, $1 \mathrm{H}), 3.88(\mathrm{~s}, 2 \mathrm{H}), 3.82-3.73(\mathrm{~m}, 4 \mathrm{H}), 3.45-3.32(\mathrm{~m}, 1 \mathrm{H}), 2.68-2.57(\mathrm{~m}, 4 \mathrm{H}), 2.11(\mathrm{~d}, J=12.8 \mathrm{~Hz}, 2 \mathrm{H})$, $1.87(\mathrm{~d}, J=12.9 \mathrm{~Hz}, 2 \mathrm{H}), 1.80(\mathrm{~d}, J=12.9 \mathrm{~Hz}, 1 \mathrm{H}), 1.53-1.35(\mathrm{~m}, 4 \mathrm{H}), 1.33-1.19(\mathrm{~m}, 1 \mathrm{H}) .{ }^{13} \mathrm{C}$ NMR $\left(\mathrm{CDCl}_{3}\right) \delta 171.4,161.1,154.5,141.3,125.7,120.9,66.9,64.7,53.9,38.8,34.4,26.8,26.2$.

4-((4-Chloro-5,6-dimethylthieno[2,3- $d]$ pyrimidin-2-yl)methyl)morpholine (13h). General Procedure E. The residue was recrystallised from $\mathrm{CHCl}_{3} / i-\mathrm{PrOH}$ to afford the compound as pale white crystals $(1.55 \mathrm{~g}$, 70\%). LCMS $(\mathrm{m} / z): 298.1[\mathrm{M}+\mathrm{H}]^{+} . \mathrm{HPLC}: t_{\mathrm{R}} 4.925 \mathrm{~min} .{ }^{1} \mathrm{H} \mathrm{NMR}\left(\mathrm{CDCl}_{3}\right) \delta 3.96(\mathrm{~s}, 2 \mathrm{H}), 3.87-3.79(\mathrm{~m}$, 4H), $2.76(\mathrm{~s}, 4 \mathrm{H}), 2.53(\mathrm{~d}, J=0.5 \mathrm{~Hz}, 3 \mathrm{H}), 2.50(\mathrm{~s}, 3 \mathrm{H}) .{ }^{13} \mathrm{C} \mathrm{NMR}\left(\mathrm{CDCl}_{3}\right) \delta 168.9,153.5,136.4,128.0$, $125.1,118.4,66.3,63.9,53.4,14.3,14.2$.

4-((4-Chloro-6-cyclohexylthieno[2,3- $d]$ pyrimidin-2-yl)methyl)morpholine (13i). The residue was chromatographed on silica (1:99 Et $3 \mathrm{~N}:$ EtOAc) affording the compound as a gold oil which later solidified under vacuum to produce a light yellow/white solid (1.64 g, 64\%). LCMS $(\mathrm{m} / \mathrm{z}): 352.1[\mathrm{M}+\mathrm{H}]^{+}$. HPLC: $t_{\mathrm{R}}$ 6.663 min. ${ }^{1} \mathrm{H}$ NMR $\left(\mathrm{CDCl}_{3}\right) \delta 7.05(\mathrm{~d}, J=1.1 \mathrm{~Hz}, 1 \mathrm{H}), 3.85(\mathrm{~s}, 2 \mathrm{H}), 3.78-3.73(\mathrm{~m}, 4 \mathrm{H}), 2.95-2.83(\mathrm{~m}$, 
1H), $2.64-2.55(\mathrm{~m}, 4 \mathrm{H}), 2.10(\mathrm{dd}, J=13.4,1.3 \mathrm{~Hz}, 2 \mathrm{H}), 1.91-1.83(\mathrm{~m}, 2 \mathrm{H}), 1.80-1.71(\mathrm{~m}, 1 \mathrm{H}), 1.57-$ $1.35(\mathrm{~m}, 4 \mathrm{H}), 1.32-1.21(\mathrm{~m}, 1 \mathrm{H}) .{ }^{13} \mathrm{C} \mathrm{NMR}\left(\mathrm{CDCl}_{3}\right) \delta 168.6,160.9,155.3,153.3,128.7,113.7,66.9,65.0$, $53.8,40.5,34.8,26.3,25.8$.

4-((4-Chlorothieno[2,3- $d]$ pyrimidin-2-yl)methyl)morpholine (13j). General Procedure E. The residue was chromatographed on silica (1:99 $\left.\mathrm{Et}_{3} \mathrm{~N}: \mathrm{EtOAc}\right)$ which afforded the compound as a gold oil later solidifying under vacuum $(1.12 \mathrm{~g}, 73 \%)$. LCMS $(\mathrm{m} / \mathrm{z}): 270.0[\mathrm{M}+\mathrm{H}]^{+}$. HPLC: $t_{\mathrm{R}} 1.169 \mathrm{~min} .{ }^{1} \mathrm{H} \mathrm{NMR}\left(\mathrm{CDCl}_{3}\right) \delta 7.58$ $(\mathrm{d}, J=6.0 \mathrm{~Hz}, 1 \mathrm{H}), 7.41(\mathrm{~d}, J=6.0 \mathrm{~Hz}, 1 \mathrm{H}), 3.91(\mathrm{~s}, 2 \mathrm{H}), 3.81-3.74(\mathrm{~m}, 4 \mathrm{H}), 2.70-2.60(\mathrm{~m}, 4 \mathrm{H}) .{ }^{13} \mathrm{C}$ NMR $\left(\mathrm{CDCl}_{3}\right) \delta 169.5,162.1,155.1,128.2,127.9,119.8,66.9,64.9,53.9$.

\section{2-(Morpholinomethyl)- $N$-(3-(trifluoromethyl)phenyl)-6,7-dihydro-5H-}

cyclopenta[4,5]thieno[2,3- $\boldsymbol{d}]$ pyrimidin-4-amine (14a). General Procedure F. The residue was chromatographed on silica (1:99 $\mathrm{Et}_{3} \mathrm{~N}$ :EtOAc) and the resulting residue recrystallised from $\mathrm{CHCl}_{3}$-petroleum ether to afford the title compound as a white powder $(127 \mathrm{mg}, 52 \%)$. LCMS $(\mathrm{m} / z): 435.1[\mathrm{M}+\mathrm{H}]^{+}$. HPLC: $t_{\mathrm{R}}$ 6.750 min. HRMS (m/z): $\mathrm{C}_{21} \mathrm{H}_{21} \mathrm{~F}_{3} \mathrm{~N}_{4} \mathrm{OS}$ requires 435.1467 [M $\left.+\mathrm{H}\right]^{+}$; found 435.1464. ${ }^{1} \mathrm{H} \mathrm{NMR}\left(d_{6}\right.$-acetone) $\delta 8.49(\mathrm{~s}, 1 \mathrm{H}), 8.13(\mathrm{~d}, J=8.2 \mathrm{~Hz}, 1 \mathrm{H}), 7.86(\mathrm{~s}, 1 \mathrm{H}), 7.58(\mathrm{t}, J=8.0 \mathrm{~Hz}, 1 \mathrm{H}), 7.40(\mathrm{~d}, J=7.7 \mathrm{~Hz}, 1 \mathrm{H}), 3.68$ (s, 2H), $3.66-3.59(\mathrm{~m}, 4 \mathrm{H}), 3.31(\mathrm{ddd}, J=5.7,3.5,1.7 \mathrm{~Hz}, 2 \mathrm{H}), 3.09-2.99(\mathrm{~m}, 2 \mathrm{H}), 2.63-2.58(\mathrm{~m}, 4 \mathrm{H})$, $2.58-2.49(\mathrm{~m}, 2 \mathrm{H}) .{ }^{13} \mathrm{C}$ NMR $\left(d_{6}\right.$-acetone) $\delta 173.4,161.6,154.7,141.3,137.8,131.1(\mathrm{q}, J=32.0 \mathrm{~Hz}), 130.2$, $125.3(\mathrm{q}, J=272.1 \mathrm{~Hz}), 125.1,119.9(\mathrm{~d}, J=3.9 \mathrm{~Hz}), 118.2(\mathrm{~d}, J=4.1 \mathrm{~Hz}), 113.4,67.5,65.8,54.5,30.1,29.6$, 28.5.

2-(Morpholinomethyl)- $N$-(3-(trifluoromethyl)phenyl)-6,7,8,9-tetrahydro-5Hcyclohepta[4,5]thieno[2,3d]pyrimidin-4-amine (14b). General Procedure F. The residue was chromatographed on silica (1:99 $\mathrm{Et}_{3} \mathrm{~N}$ :EtOAc) to afford the title compound as a gold oil $(90.3 \mathrm{mg}, 12 \%)$. LCMS $(\mathrm{m} / \mathrm{z}): 463.1[\mathrm{M}+\mathrm{H}]^{+}$. HPLC: $t_{\mathrm{R}} 7.226$ min. HRMS $(\mathrm{m} / z): \mathrm{C}_{21} \mathrm{H}_{21} \mathrm{~F}_{3} \mathrm{~N}_{4} \mathrm{OS}$ requires $463.1782[\mathrm{M}+\mathrm{H}]^{+}$; found 463.1774. ${ }^{1} \mathrm{H} \mathrm{NMR}\left(\mathrm{CDCl}_{3}\right) \delta$ $8.10(\mathrm{~s}, 1 \mathrm{H}), 7.75(\mathrm{dd}, J=8.1,1.7 \mathrm{~Hz}, 1 \mathrm{H}), 7.45(\mathrm{t}, J=7.9 \mathrm{~Hz}, 1 \mathrm{H}), 7.33(\mathrm{~d}, J=7.8 \mathrm{~Hz}, 1 \mathrm{H}), 7.22(\mathrm{~s}, 1 \mathrm{H})$, $3.76-3.73(\mathrm{~m}, 4 \mathrm{H}), 3.74(\mathrm{~s}, 2 \mathrm{H}), 3.16-3.08(\mathrm{~m}, 2 \mathrm{H}), 2.93-2.89(\mathrm{~m}, 2 \mathrm{H}), 2.67-2.59(\mathrm{~m}, 4 \mathrm{H}), 1.98-1.78$ $(\mathrm{m}, 4 \mathrm{H}), 1.88-1.79(\mathrm{~m}, 2 \mathrm{H}) .{ }^{13} \mathrm{C} \mathrm{NMR}\left(\mathrm{CDCl}_{3}\right) \delta 166.4,160.1,154.1,139.6,138.9,131.3(\mathrm{q}, J=32.4 \mathrm{~Hz})$, 129.4, 129.3, $124.1(\mathrm{q}, J=272.5 \mathrm{~Hz}), 123.6,119.9(\mathrm{q}, J=3.8 \mathrm{~Hz}), 117.5(\mathrm{q}, J=3.9 \mathrm{~Hz}), 116.4,67.0,65.1$, 53.8, 30.4, 30.3, 29.1, 26.9, 26.4 . 
2-(Morpholinomethyl)- $N$-(3-(trifluoromethyl)phenyl)-5,6,7,8,9,10hexahydrocycloocta[4,5]thien $\quad$ o[2,3d]pyrimidin-4-amine (14c). General Procedure F. The residue was chromatographed on silica (1:99 $\mathrm{Et}_{3} \mathrm{~N}:$ EtOAc) to afford the compound as gold oil $(60.2 \mathrm{mg}, 11 \%)$. LCMS $(\mathrm{m} / \mathrm{z}): 477.2[\mathrm{M}+\mathrm{H}]^{+}$. HPLC: $t_{\mathrm{R}}$ 7.442 min. $\mathrm{HRMS}(\mathrm{m} / z): \mathrm{C}_{24} \mathrm{H}_{27} \mathrm{~F}_{3} \mathrm{~N}_{4} \mathrm{O}$ requires $477.194[\mathrm{M}+\mathrm{H}]^{+}$; found 477.193. ${ }^{1} \mathrm{H} \mathrm{NMR}\left(\mathrm{CDCl}_{3}\right) \delta 8.23$ (s, 1H), $7.77(\mathrm{dd}, J=8.1,1.7 \mathrm{~Hz}, 1 \mathrm{H}), 7.46(\mathrm{t}, J=7.9 \mathrm{~Hz}, 1 \mathrm{H}), 7.35(\mathrm{~s}, 1 \mathrm{H}), 7.32(\mathrm{~d}, J=5.8 \mathrm{~Hz}, 1 \mathrm{H}), 3.77(\mathrm{~s}$, 2H), $3.78-3.74(\mathrm{~m}, 4 \mathrm{H}), 3.07(\mathrm{dd}, J=11.8,5.5 \mathrm{~Hz}, 2 \mathrm{H}), 2.95-2.88(\mathrm{~m}, 2 \mathrm{H}), 2.69-2.62(\mathrm{~m}, 4 \mathrm{H}), 1.92-$ $1.81(\mathrm{~m}, 2 \mathrm{H}), 1.78-1.69(\mathrm{~m}, 2 \mathrm{H}, 0), 1.60-1.51(\mathrm{~m}, 2 \mathrm{H}), 1.39(\mathrm{dd}, J=10.5,5.3 \mathrm{~Hz}, 2 \mathrm{H}) .{ }^{13} \mathrm{C} \mathrm{NMR}\left(\mathrm{CDCl}_{3}\right)$ $\delta 167.0,160.3,153.9,139.6,138.3,131.4(\mathrm{q}, J=32.5 \mathrm{~Hz}), 129.4,126.5,124.1(\mathrm{~d}, J=272.5 \mathrm{~Hz}), 123.45$, $119.9(\mathrm{q}, J=3.8 \mathrm{~Hz}), 117.4(\mathrm{q}, J=3.9 \mathrm{~Hz}), 115.2,67.1,65.3,53.9,31.7,30.1,28.0,26.3,26.2,25.2$.

2-(Morpholinomethyl)-6-phenyl- $N$-(3-(trifluoromethyl)phenyl)thieno[2,3- $d]$ pyrimidin-4-amine $(14 d)$.

General Procedure F. The residue was chromatographed on silica (1:99 $\mathrm{Et}_{3} \mathrm{~N}$ :EtOAc) to afford the title compound as a gold solid $(244 \mathrm{mg}, 51 \%)$. LCMS $(\mathrm{m} / \mathrm{z}): 471.1[\mathrm{M}+\mathrm{H}]^{+}$. HPLC: $t_{\mathrm{R}} 7.124 \mathrm{~min}$. HRMS $(\mathrm{m} / \mathrm{z})$ : $\mathrm{C}_{24} \mathrm{H}_{21} \mathrm{~F}_{3} \mathrm{~N}_{4} \mathrm{OS}$ requires $471.1467[\mathrm{M}+\mathrm{H}]^{+}$; found 471.1461. ${ }^{1} \mathrm{H}$ NMR $\left(d_{6}\right.$-DMSO) $\delta 9.88(\mathrm{~s}, 1 \mathrm{H}), 8.58(\mathrm{~s}$, $1 \mathrm{H}), 8.25(\mathrm{~s}, 1 \mathrm{H}), 8.18(\mathrm{~d}, J=8.18 \mathrm{~Hz}, 1 \mathrm{H}), 7.73(\mathrm{~d}, J=7.5 \mathrm{~Hz}, 2 \mathrm{H}), 7.62(\mathrm{t}, J=8.0 \mathrm{~Hz}, 1 \mathrm{H}), 7.53(\mathrm{t}, J=7.6$ $\mathrm{Hz}, 2 \mathrm{H}), 7.43(\mathrm{t}, J=7.8 \mathrm{~Hz}, 2 \mathrm{H}), 3.66(\mathrm{~s}, 2 \mathrm{H}), 3.62-3.57(\mathrm{~m}, 4 \mathrm{H}), 2.58-2.52(\mathrm{~m}, 4 \mathrm{H}) .{ }^{13} \mathrm{C}$ NMR $\left(d_{6}-\mathrm{DMSO}\right)$ $\delta 166.6,161.5,153.8,140.5,139.2,133.0,129.7,129.4,129.4(\mathrm{~d}, J=31.4 \mathrm{~Hz}) 128.8,125.8,124.3(\mathrm{q}, J=$ 272.4 Hz), 123.7, $118.9(\mathrm{~d}, J=3.8 \mathrm{~Hz}), 116.8,116.6(\mathrm{~d}, J=4.1 \mathrm{~Hz}), 114.9,66.2,64.8,53.3$.

2-(Morpholinomethyl)-5-phenyl- $N$-(3-(trifluoromethyl)phenyl)thieno[2,3- $d]$ pyrimidin-4-amine $\quad(14 \mathrm{e})$.

General Procedure F. The residue was chromatographed on silica (1:29:70 $\mathrm{Et}_{3} \mathrm{~N}$ :petroleum ether:EtOAc) to afford the compound as a gold oil $(307 \mathrm{mg}, 75 \%)$. LCMS $(\mathrm{m} / \mathrm{z}): 471.1[\mathrm{M}+\mathrm{H}]^{+}$. HPLC: $t_{\mathrm{R}} 7.195 \mathrm{~min}$. HRMS $(m / z): \mathrm{C}_{24} \mathrm{H}_{21} \mathrm{~F}_{3} \mathrm{~N}_{4} \mathrm{OS}$ requires $471.1465[\mathrm{M}+\mathrm{H}]^{+}$; found 471.1461. ${ }^{1} \mathrm{H} \mathrm{NMR}\left(\mathrm{CDCl}_{3}\right) \delta 8.08(\mathrm{~s}, 1 \mathrm{H}), 7.60$ $(\mathrm{dd}, J=6.4,2.5 \mathrm{~Hz}, 3 \mathrm{H}), 7.55(\mathrm{~d}, J=2.2 \mathrm{~Hz}, 1 \mathrm{H}), 7.54(\mathrm{~d}, J=3.8 \mathrm{~Hz}, 1 \mathrm{H}), 7.34(\mathrm{t}, J=7.9 \mathrm{~Hz}, 1 \mathrm{H}), 7.25(\mathrm{dd}$, $J=13.4,5.5 \mathrm{~Hz}, 2 \mathrm{H}), 7.21(\mathrm{~s}, 1 \mathrm{H}), 7.01(\mathrm{~s}, 1 \mathrm{H}), 3.85(\mathrm{~s}, 2 \mathrm{H}), 3.82-3.77(\mathrm{~m}, 4 \mathrm{H}), 2.76-2.66(\mathrm{~m}, 4 \mathrm{H}) .{ }^{13} \mathrm{C}$ $\operatorname{NMR}\left(\mathrm{CDCl}_{3}\right) \delta 168.5,161.9,154.6,139.3,135.9,133.77,131.33(\mathrm{q}, J=32.2 \mathrm{~Hz}), 129.6,129.4,129.3(\mathrm{~d}, J$ $=2.8 \mathrm{~Hz}), 123.3(\mathrm{q}, J=272.2 \mathrm{~Hz}), 122.3,121.5,119.6(\mathrm{q}, J=3.8 \mathrm{~Hz}), 116.5(\mathrm{q}, J=4.0 \mathrm{~Hz}), 113.3,67.0,65.3$, 53.8 . 
General Procedure F. The reaction precipitate was collected under vacuum and washed with cold $i$-PrOH to afford the compound as a white solid $(37.5 \mathrm{mg}, 55 \%)$. LCMS $(\mathrm{m} / \mathrm{z}): 485.2[\mathrm{M}+\mathrm{H}]^{+}$. HPLC: $t_{\mathrm{R}} 7.162 \mathrm{~min}$. $\operatorname{HRMS}(\mathrm{m} / \mathrm{z}): \mathrm{C}_{25} \mathrm{H}_{23} \mathrm{~F}_{3} \mathrm{~N}_{4} \mathrm{OS}$ requires 485.1624 [M + H] $]^{+}$; found 485.1617. ${ }^{1} \mathrm{H}$ NMR $\left(d_{6}-\mathrm{DMSO}\right) \delta 10.39(\mathrm{~s}$, $1 \mathrm{H}), 8.36(\mathrm{~d}, J=8.5 \mathrm{~Hz}, 1 \mathrm{H}), 8.19(\mathrm{~s}, 1 \mathrm{H}), 7.92(\mathrm{~s}, 1 \mathrm{H}), 7.61(\mathrm{t}, J=8.0 \mathrm{~Hz}, 1 \mathrm{H}), 7.45(\mathrm{~d}, J=7.7 \mathrm{~Hz}, 1 \mathrm{H})$, $7.39-7.33(\mathrm{~m}, 4 \mathrm{H}), 7.30-7.25(\mathrm{~m}, 1 \mathrm{H}), 4.52(\mathrm{~s}, 2 \mathrm{H}), 4.30(\mathrm{~s}, 2 \mathrm{H}), 3.89(\mathrm{~s}, 4 \mathrm{H}), 3.40(\mathrm{~s}, 4 \mathrm{H}) .{ }^{13} \mathrm{C} \mathrm{NMR}\left(d_{6^{-}}\right.$ DMSO) $\delta 166.2,153.9,142.6,139.9,139.2,129.8,129.4,129.1,128.7,128.7,126.8,125.3,124.2(\mathrm{q}, J=$ $272.3 \mathrm{~Hz}), 119.6,117.6(\mathrm{~d}, J=3.9 \mathrm{~Hz}), 117.4,116.8,63.2,59.8,51.8,36.2$.

\section{5-Cyclohexyl-2-(morpholinomethyl)- $N$-(3-(trifluoromethyl)phenyl)thieno[2,3- $d]$ pyrimidin-4-amine}

(14g). General Procedure F. The residue was chromatographed on silica (1:29:70 Et 3 N:petroleum ether: EtOAc) to afford the title compound as a yellow oil which later solidified under vacuum (260 mg, 66\%). LCMS $(\mathrm{m} / \mathrm{z}): 477.2[\mathrm{M}+\mathrm{H}]^{+}$. HPLC: $t_{\mathrm{R}} 7.618 \mathrm{~min}$. HRMS $(\mathrm{m} / \mathrm{z}): \mathrm{C}_{24} \mathrm{H}_{27} \mathrm{~F}_{3} \mathrm{~N}_{4} \mathrm{OS}$ requires $477.1937[\mathrm{M}+\mathrm{H}]^{+}$; found 477.193. ${ }^{1} \mathrm{H}$ NMR $\left(\mathrm{CDCl}_{3}\right) \delta 8.33(\mathrm{~s}, 1 \mathrm{H}), 7.75(\mathrm{dd}, J=8.0,0.9 \mathrm{~Hz}, 1 \mathrm{H}), 7.49(\mathrm{t}, J=7.9 \mathrm{~Hz}, 1 \mathrm{H}), 7.37$ $(\mathrm{d}, J=6.6 \mathrm{~Hz}, 2 \mathrm{H}), 7.01(\mathrm{~s}, 1 \mathrm{H}), 3.80(\mathrm{~s}, 2 \mathrm{H}), 3.79-3.75(\mathrm{~m}, 4 \mathrm{H}), 2.86(\mathrm{t}, J=9.6 \mathrm{~Hz}, 1 \mathrm{H}), 2.74-2.62(\mathrm{~m}$, 4H), $2.23(\mathrm{~d}, J=10.4 \mathrm{~Hz}, 2 \mathrm{H}), 2.04-1.98(\mathrm{~m}, 2 \mathrm{H}), 1.89(\mathrm{~d}, J=12.9 \mathrm{~Hz}, 1 \mathrm{H}), 1.64-1.47$ (m, 4H), $1.45-$ $1.31(\mathrm{~m}, 1 \mathrm{H}) .{ }^{13} \mathrm{C} \mathrm{NMR}\left(\mathrm{CDCl}_{3}\right) \delta 169.7,161.2,154.7,139.6,138.8,131.6(\mathrm{q}, J=32.3 \mathrm{~Hz}), 129.6,124.2(\mathrm{q}$, $J=272.4 \mathrm{~Hz}), 123.2,120.1(\mathrm{q}, J=3.8 \mathrm{~Hz}), 117.3(\mathrm{q}, J=4.0 \mathrm{~Hz}), 117.2,114.1,67.1,65.2,53.9,41.3,34.2$, $26.9,26.1$.

\section{5,6-Dimethyl-2-(morpholinomethyl)- $N$-(3-(trifluoromethyl)phenyl)thieno[2,3- $d]$ pyrimidin-4-amine}

(14h). General Procedure F. The residue was chromatographed on silica (1:29:70 Et 3 N:petroleum ether/:EtOAc) to afford the title compound as a gold oil (214 mg, 40\%). LCMS (m/z): $423.2[\mathrm{M}+\mathrm{H}]^{+}$. HPLC: $t_{\mathrm{R}} 6.577 \mathrm{~min}$. HRMS $(\mathrm{m} / z): \mathrm{C}_{20} \mathrm{H}_{21} \mathrm{~F}_{3} \mathrm{~N}_{4} \mathrm{OS}$ requires $423.1464[\mathrm{M}+\mathrm{H}]^{+}$; found 423.1461. ${ }^{1} \mathrm{H} \mathrm{NMR}\left(\mathrm{CDCl}_{3}\right) \delta$ $8.20(\mathrm{~s}, 1 \mathrm{H}), 7.81(\mathrm{dd}, J=8.1,1.2 \mathrm{~Hz}, 1 \mathrm{H}), 7.46(\mathrm{t}, J=8.0 \mathrm{~Hz}, 1 \mathrm{H}), 7.38(\mathrm{~s}, 1 \mathrm{H}), 7.34(\mathrm{~d}, J=7.8 \mathrm{~Hz}, 1 \mathrm{H})$, $3.78-3.75(\mathrm{~m}, 6 \mathrm{H}), 2.68-2.63(\mathrm{~m}, 4 \mathrm{H}), 2.60(\mathrm{~s}, 3 \mathrm{H}), 2.47(\mathrm{~s}, 3 \mathrm{H}) .{ }^{13} \mathrm{C} \mathrm{NMR}\left(\mathrm{CDCl}_{3}\right) \delta 166.8,160.5,154.3$, $139.5,131.9,131.4(\mathrm{q}, J=32.3 \mathrm{~Hz}), 129.5,123.8(\mathrm{q}, J=272.2 \mathrm{~Hz}), 123.5(\mathrm{~d}, J=1.2 \mathrm{~Hz}), 120.0(\mathrm{q}, J=3.8$ $\mathrm{Hz}), 117.4(\mathrm{q}, J=4.0 \mathrm{~Hz}), 116.1,67.1,65.3,53.9,14.6,13.7$. 
6-Cyclohexyl-2-(morpholinomethyl)- $N$-(3-(trifluoromethyl)phenyl)thieno[2,3- $d]$ pyrimidin-4-amine

(14i). General Procedure F. The residue was chromatographed on silica (1:99 $\mathrm{Et}_{3} \mathrm{~N}$ :EtOAc) to afford the compound as a white solid $(258 \mathrm{mg}, 54 \%)$. LCMS $(\mathrm{m} / \mathrm{z}): 477.2[\mathrm{M}+\mathrm{H}]^{+}$. HPLC: $t_{\mathrm{R}} 7.666 \mathrm{~min}$. HRMS $(\mathrm{m} / z)$ : $\mathrm{C}_{24} \mathrm{H}_{27} \mathrm{~F}_{3} \mathrm{~N}_{4} \mathrm{OS}$ requires $477.1942[\mathrm{M}+\mathrm{H}]^{+}$; found 477.193. ${ }^{1} \mathrm{H} \mathrm{NMR}\left(400 \mathrm{MHz}, d_{6}-\mathrm{DMSO}\right) \delta 9.72(\mathrm{~s}, 1 \mathrm{H})$, $8.57(\mathrm{~s}, 1 \mathrm{H}), 8.17(\mathrm{~d}, J=8.3 \mathrm{~Hz}, 1 \mathrm{H}), 7.62(\mathrm{~d}, J=0.9 \mathrm{~Hz}, 1 \mathrm{H}), 7.59(\mathrm{~d}, J=8.1 \mathrm{~Hz}, 1 \mathrm{H}), 7.39(\mathrm{~d}, J=7.7 \mathrm{~Hz}$, $1 \mathrm{H}), 3.64(\mathrm{~s}, 2 \mathrm{H}), 3.61-3.56(\mathrm{~m}, 4 \mathrm{H}), 2.90(\mathrm{tt}, J=10.8,5.5 \mathrm{~Hz}, 1 \mathrm{H}, \mathrm{A}), 2.56-2.51(\mathrm{~m}, 4 \mathrm{H}), 2.07(\mathrm{~d}, J=9.7$ $\mathrm{Hz}, 2 \mathrm{H}), 1.81(\mathrm{dd}, J=9.3,3.0 \mathrm{~Hz}, 2 \mathrm{H}), 1.71(\mathrm{~d}, J=12.7 \mathrm{~Hz}, 1 \mathrm{H}), 1.51-1.35(\mathrm{~m}, 4 \mathrm{H}), 1.26(\mathrm{ddd}, J=17.7$, 10.6, $6.0 \mathrm{~Hz}, 1 \mathrm{H}) .{ }^{13} \mathrm{C}$ NMR $\left(d_{6}\right.$-DMSO) $\delta 165.9,160.5,153.4,148.5,140.7,129.7,129.3(\mathrm{~d}, J=31.4 \mathrm{~Hz})$, $124.3(\mathrm{q}, J=272.1 \mathrm{~Hz}), 123.6,118.7(\mathrm{~d}, J=3.8 \mathrm{~Hz}), 116.5(\mathrm{~d}, J=4.0 \mathrm{~Hz}), 115.6,113.5,66.2,64.7,53.2$, $39.1,34.4,25.6,25.4$.

2-(Morpholinomethyl)- $N$-(3-(trifluoromethyl)phenyl)thieno[2,3- $d]$ pyrimidin-4-amine $\quad(14 \mathbf{j})$. General Procedure F. The precipitate was filtered and washed with cold $i$-PrOH affording the compound as a brown solid (199 mg, 45\%). LCMS (m/z): $395.1[\mathrm{M}+\mathrm{H}]^{+}$. HPLC: $t_{\mathrm{R}} 5.894 \mathrm{~min}$. HRMS $(\mathrm{m} / z): \mathrm{C}_{18} \mathrm{H}_{17} \mathrm{~F}_{3} \mathrm{~N}_{4} \mathrm{OS}$ requires $395.1106[\mathrm{M}+\mathrm{H}]^{+}$; found $395.1148 .{ }^{1} \mathrm{H} \mathrm{NMR}\left(d_{6}\right.$-DMSO) $\delta 10.68(\mathrm{~s}, 1 \mathrm{H}), 8.43(\mathrm{~d}, J=8.5 \mathrm{~Hz}, 1 \mathrm{H})$, $8.29(\mathrm{~d}, J=5.9 \mathrm{~Hz}, 2 \mathrm{H}), 7.82(\mathrm{~d}, J=6.0 \mathrm{~Hz}, 1 \mathrm{H}), 7.62(\mathrm{t}, J=8.0 \mathrm{~Hz}, 1 \mathrm{H}), 7.46(\mathrm{~d}, J=7.7 \mathrm{~Hz}, 1 \mathrm{H}), 4.56(\mathrm{~s}$, 2H), $3.92(\mathrm{~s}, 4 \mathrm{H}), 3.40(\mathrm{~s}, 4 \mathrm{H}) .{ }^{13} \mathrm{C} \mathrm{NMR}\left(d_{6}\right.$-DMSO) $\delta 166.6,154.7,139.9,129.7,129.2(\mathrm{~d}, J=31.6 \mathrm{~Hz})$, 128.8, 125.4, 124.7, $124.2(\mathrm{q}, J=272.4 \mathrm{~Hz}), 120.3,119.7(\mathrm{~d}, J=3.9 \mathrm{~Hz}), 117.7(\mathrm{~d}, J=3.9 \mathrm{~Hz}), 116.4,63.3$, $59.8,51.9$

6-Benzyl- $N, N$-dimethyl-2-(morpholinomethyl)thieno[2,3-d]pyrimidin-4-amine (15). General Procedure F. The residue was chromatographed on silica (1:99 Et 3 N:EtOAc) to afford the compound as a gold oil (91 mg, 33\%). LCMS $(m / z): 369.2[\mathrm{M}+\mathrm{H}]^{+}$. HPLC: $t_{\mathrm{R}} 6.012 \mathrm{~min}, 93 \%$ purity $(214 \mathrm{~nm})$. HRMS $(\mathrm{m} / \mathrm{z})$ : $\mathrm{C}_{20} \mathrm{H}_{24} \mathrm{~N}_{4} \mathrm{OS}$ requires $369.1747[\mathrm{M}+\mathrm{H}]^{+}$; found 369.1744. ${ }^{1} \mathrm{H} \mathrm{NMR}\left(\mathrm{CDCl}_{3}\right) \delta 7.30(\mathrm{dd}, J=9.7,4.8 \mathrm{~Hz}, 1 \mathrm{H})$, $7.26-7.20(\mathrm{~m}, 3 \mathrm{H}), 7.11(\mathrm{~s}, 1 \mathrm{H}), 4.14(\mathrm{~s}, 2 \mathrm{H}), 3.80-3.72(\mathrm{~m}, 4 \mathrm{H}), 3.69(\mathrm{~s}, 2 \mathrm{H}), 3.32(\mathrm{~s}, 6 \mathrm{H}), 2.71-2.60(\mathrm{~m}$, $1 \mathrm{H}) .{ }^{13} \mathrm{C} \mathrm{NMR}\left(\mathrm{CDCl}_{3}\right) \delta 169.6,160.7,160.0,157.6,139.1,138.2,128.6,128.5,126.7,118.7,114.5,66.8$, $65.0,53.6,39.8,36.9$.

2-(Morpholinomethyl)- $N$-phenyl-5,6,7,8-tetrahydrobenzo[4,5]thieno[2,3- $d]$ pyrimidin-4-amine

(16a).

General Procedure F. The residue was eluted through a silica gel column (99:1 EtOAc:Et 3 N) and proceeded 
to afford the title compound as a light pink oil which later solidified at room temperature (48.8 $\mathrm{mg}, 20 \%)$. mp: 129-135 ${ }^{\circ} \mathrm{C} . \mathrm{LCMS}(\mathrm{m} / \mathrm{z}): 381.2[\mathrm{M}+\mathrm{H}]^{+}$. HPLC: $t_{\mathrm{R}} 6.294 \mathrm{~min} . \mathrm{HRMS}(\mathrm{m} / \mathrm{z}): \mathrm{C}_{21} \mathrm{H}_{24} \mathrm{~N}_{4} \mathrm{OS}$ requires 381.1748 $[\mathrm{M}+\mathrm{H}]^{+}$; found 381.1744. ${ }^{1} \mathrm{H} \mathrm{NMR}\left(\mathrm{CDCl}_{3}\right) \delta 7.76-7.72(\mathrm{~m}, 2 \mathrm{H}), 7.39-7.33(\mathrm{~m}, 2 \mathrm{H}), 7.17(\mathrm{~s}, 1 \mathrm{H}), 7.13$ $-7.07(\mathrm{~m}, 1 \mathrm{H}), 3.80-3.77(\mathrm{~m}, 4 \mathrm{H}),), 3.76(\mathrm{~s}, 2 \mathrm{H}), 3.10-3.02(\mathrm{~m}, J=6.0 \mathrm{~Hz}, 2 \mathrm{H}), 2.88-2.78(\mathrm{~m}, 2 \mathrm{H}), 2.69$ - $2.62(\mathrm{~m}, 4 \mathrm{H}), 2.02-1.96(\mathrm{~m}, 2 \mathrm{H}), 1.96-1.89(\mathrm{~m}, 2 \mathrm{H}) .{ }^{13} \mathrm{C} \mathrm{NMR}\left(\mathrm{CDCl}_{3}\right) \delta 167.0,160.7,154.7,138.9$, $134.4,128.9,124.4,123.5,120.5,114.9,67.0,65.1,53.9,26.5,25.5,22.6,22.5$.

\section{$N$-(3-Fluorophenyl)-2-(morpholinomethyl)-5,6,7,8-tetrahydrobenzo[4,5]thieno[2,3-d]pyrimidin-4-}

amine (16b). General Procedure F. Chromatographed on silica (1:99 EtOAc:Et $3 \mathrm{~N})$ to give the final product as a yellow/orange solid (90.2 mg, 17\%). mp: 141-150 ${ }^{\circ} \mathrm{C}$. LCMS $(\mathrm{m} / \mathrm{z}): 399.2[\mathrm{M}+\mathrm{H}]^{+}$. HPLC: $t_{\mathrm{R}} 6.569 \mathrm{~min}$. $\operatorname{HRMS}(m / z): \mathrm{C}_{21} \mathrm{H}_{23} \mathrm{FN}_{4} \mathrm{OS}$ requires $399.1654[\mathrm{M}+\mathrm{H}]^{+}$; found 399.1649. ${ }^{1} \mathrm{H} \mathrm{NMR}\left(\mathrm{CDCl}_{3}\right) \delta 7.97(\mathrm{dt}, J=$ 11.5, $2.1 \mathrm{~Hz}, 1 \mathrm{H}), 7.32-7.26(\mathrm{~m}, 1 \mathrm{H}), 7.24-7.19(\mathrm{~m}, 2 \mathrm{H}), 6.80(\mathrm{td}, J=8.2,1.7 \mathrm{~Hz}, 1 \mathrm{H}), 3.83-3.80(\mathrm{~m}$, 4H), $3.80(\mathrm{~s}, 2 \mathrm{H}), 3.06(\mathrm{t}, J=5.7 \mathrm{~Hz}, 2 \mathrm{H}), 2.86(\mathrm{t}, J=5.7 \mathrm{~Hz}, 2 \mathrm{H}), 2.72-2.65(\mathrm{~m}, 4 \mathrm{H}), 2.02-1.97(\mathrm{~m}, 2 \mathrm{H})$, $1.97-1.91(\mathrm{~m}, 2 \mathrm{H}) .{ }^{13} \mathrm{C} \mathrm{NMR}\left(\mathrm{CDCl}_{3}\right) \delta 165.8(\mathrm{~d}, J=247.2 \mathrm{~Hz}), 161.9,160.7,154.4,140.7(\mathrm{~d}, J=11.2 \mathrm{~Hz})$, $134.9,129.9(\mathrm{~d}, J=9.7 \mathrm{~Hz}), 124.3,115.2(\mathrm{~d}, J=2.7 \mathrm{~Hz}), 115.1,109.9(\mathrm{~d}, J=21.6 \mathrm{~Hz}), 107.78 \mathrm{~d}, J=27.1$ Hz), 67.1, 65.1, 53.9, 26.5, 25.6, 22.6, 22.5.

$N$-(3-Methoxyphenyl)-2-(morpholinomethyl)-5,6,7,8-tetrahydrobenzo $\quad[4,5]$ thieno[2,3- $d]$ pyrimidin-4amine (16c). General Procedure F. This residue was purified using column chromatography (50:50 petroleum ether/EtOAc) to afford the final product as a yellow oil $(60.5 \mathrm{mg}, 18 \%) .{ }^{1} \mathrm{H} \mathrm{NMR}\left(\mathrm{CDCl}_{3}\right) \delta 7.65(\mathrm{~s}, 1 \mathrm{H}, \mathrm{H})$, $7.25(\mathrm{t}, J=8.1 \mathrm{~Hz}, 1 \mathrm{H}), 7.18(\mathrm{~s}, 1 \mathrm{H}), 7.12(\mathrm{ddd}, J=8.2,2.1,0.8 \mathrm{~Hz}, 1 \mathrm{H}), 6.65(\mathrm{ddd}, J=8.2,2.5,0.8 \mathrm{~Hz}, 1 \mathrm{H})$, $3.86(\mathrm{~s}, 3 \mathrm{H}), 3.81-3.76(\mathrm{~m}, J=8.3,3.5 \mathrm{~Hz}, 6 \mathrm{H}), 3.06(\mathrm{t}, J=5.9 \mathrm{~Hz}, 2 \mathrm{H}), 2.84(\mathrm{t}, J=5.9 \mathrm{~Hz}, 2 \mathrm{H}), 2.67(\mathrm{~s}$, 4H), $2.03-1.96(\mathrm{~m}, 2 \mathrm{H}), 1.96-1.89(\mathrm{~m}, 2 \mathrm{H})$. LCMS $(\mathrm{m} / \mathrm{z}): 411.3[\mathrm{M}+\mathrm{H}]^{+}$. HPLC: $t_{\mathrm{R}} 6.521 \mathrm{~min} . \mathrm{HRMS}$ $(m / z): \mathrm{C}_{22} \mathrm{H}_{26} \mathrm{~N}_{4} \mathrm{O}_{2} \mathrm{~S}$ requires $411.1853[\mathrm{M}+\mathrm{H}]^{+}$; found 411.1849. ${ }^{13} \mathrm{C} \mathrm{NMR}\left(\mathrm{CDCl}_{3}\right) \delta 167.0,160.2,154.6$, $140.2,134.6,129.6,124.4,115.1,112.5,108.7,106.6,66.9,65.2,60.4,55.3,53.8,26.4,25.5,22.6,22.4$.

3-((2-(Morpholinomethyl)-5,6,7,8-tetrahydrobenzo[4,5]thieno[2,3-d]pyrimidin-4-yl)amino)phenol (17).

To a solution of $\mathrm{N}$-(3-methoxyphenyl)-2- (morpholinomethyl)-5,6,7,8 tetrahydrobenzo[4,5]thieno[2,3d]pyrimidin-4-amine $(195 \mathrm{mg}, 475 \mu \mathrm{mol})$ in DCM $(4.00 \mathrm{~mL})$ at $0{ }^{\circ} \mathrm{C}$ was added $\mathrm{BBr} 3(1 \mathrm{M}$ in DCM$)(2.37$ $\mathrm{mL}, 2.37 \mathrm{mmol}$ ). The mixture was stirred at r.t. under a $\mathrm{N}_{2}$ environment overnight, and then poured into ice- 
water. The solution was adjusted to $\mathrm{pH} 6$ by addition of sat. $\mathrm{NaHCO}_{3}$. The $\mathrm{DCM}$ was removed under reduced pressure and the aqueous residue extracted with EtOAc $(3 \times 20 \mathrm{~mL})$. The combined organic extracts were washed with brine, dried $\left(\mathrm{Na}_{2} \mathrm{SO}_{4}\right)$, filtered and concentrated in vacuo. The resulting residue was eluted through a silica gel column (5:95 MeOH:DCM) to give the title compound as a white/grey solid (100 mg, 53\%). mp: $98-105^{\circ} \mathrm{C} . \operatorname{LCMS}(\mathrm{m} / \mathrm{z}): 397.2[\mathrm{M}+\mathrm{H}]^{+}$. HPLC: $t_{\mathrm{R}} 5.850 \mathrm{~min}$. HRMS $(\mathrm{m} / z): \mathrm{C}_{21} \mathrm{H}_{24} \mathrm{~N}_{4} \mathrm{O}_{2} \mathrm{~S}$ requires $397.1699[\mathrm{M}+\mathrm{H}]^{+}$; found 397.1693. ${ }^{1} \mathrm{H} \mathrm{NMR}\left(\mathrm{CDCl}_{3}\right) \delta 8.37(\mathrm{~s}, 1 \mathrm{H}), 7.73(\mathrm{t}, J=2.0 \mathrm{~Hz}, 1 \mathrm{H}), 7.14(\mathrm{~s}, 1 \mathrm{H})$, $7.11(\mathrm{t}, J=8.1 \mathrm{~Hz}, 1 \mathrm{H}), 6.87(\mathrm{ddd}, J=8.0,2.0,0.7 \mathrm{~Hz}, 1 \mathrm{H}), 6.56(\mathrm{ddd}, J=8.1,2.3,0.7 \mathrm{~Hz}, 1 \mathrm{H}), 3.79(\mathrm{~s}, 2 \mathrm{H})$, $3.78-3.73(\mathrm{~m}, 4 \mathrm{H}), 2.98(\mathrm{t}, J=5.4 \mathrm{~Hz}, 2 \mathrm{H}), 2.80-2.72(\mathrm{~m}, 6 \mathrm{H}), 1.98-1.83(\mathrm{~m}, 4 \mathrm{H}) .{ }^{13} \mathrm{C} \mathrm{NMR}\left(\mathrm{CDCl}_{3}\right) \delta$ $166.4,160.3,157.4,154.5,139.8,134.4,129.7,124.6,115.1,111.5,111.1,108.3,66.8,64.0,52.8,26.4,25.5$, $22.5,22.4$

$N$-Methyl-2-(morpholinomethyl)-5,6,7,8-tetrahydrobenzo[4,5]thieno[2,3- $d]$ pyrimidin-4-amine (18).

General Procedure F. Upon completion of reaction the reaction vessel was stored at $-4{ }^{\circ} \mathrm{C}$ overnight. Precipitates were collected and washed with cold $i$-PrOH to afford the compound as light brown crystals (300 mg, 76\%). LCMS (m/z): 319.1[M + H] $]^{+}$HPLC: $t_{\mathrm{R}} 5.162 \mathrm{~min}$. HRMS $(\mathrm{m} / \mathrm{z}): \mathrm{C}_{16} \mathrm{H}_{22} \mathrm{~N}_{4} \mathrm{OS}$ requires 319.1593 $[\mathrm{M}+\mathrm{H}]^{+}$; found 319.1587. ${ }^{1} \mathrm{H} \mathrm{NMR}\left(\mathrm{CDCl}_{3}\right) \delta 5.23(\mathrm{dd}, J=9.4,5.2 \mathrm{~Hz}, 1 \mathrm{H}), 3.82-3.74(\mathrm{~m}, 4 \mathrm{H}), 3.71(\mathrm{~s}$, $2 \mathrm{H}), 3.10(\mathrm{~d}, J=4.8 \mathrm{~Hz}, 3 \mathrm{H}), 2.92-2.85(\mathrm{~m}, 2 \mathrm{H}), 2.82-2.75(\mathrm{~m}, 2 \mathrm{H}), 2.70-2.65(\mathrm{~m}, 4 \mathrm{H}), 1.98-1.81(\mathrm{~m}$, $4 \mathrm{H}) .{ }^{13} \mathrm{C} \mathrm{NMR}\left(\mathrm{CDCl}_{3}\right) \delta 165.9,161.0,158.0,132.8,125.2,114.6,67.1,65.4,53.9,28.1,26.5,25.5,22.7$.

$N, N$-Diethyl-2-(morpholinomethyl)-5,6,7,8-tetrahydrobenzo[4,5]thieno[2,3- $d]$ pyrimidin-4-amine (19). General Procedure F. The reaction mixture was concentrated under reduced pressure and the residue chromatographed on silica (5\% MeOH-DCM) to afford the compound as a gold oil (299 mg, 90\%). LCMS $(m / z): 361.2[\mathrm{M}+\mathrm{H}]^{+}$. HPLC: $t_{\mathrm{R}} 5.162 \mathrm{~min}$. HRMS $(m / z): \mathrm{C}_{19} \mathrm{H}_{28} \mathrm{~N}_{4} \mathrm{OS}$ requires $361.2055[\mathrm{M}+\mathrm{H}]^{+}$; found 361.2057. ${ }^{1} \mathrm{H} \mathrm{NMR}\left(\mathrm{CDCl}_{3}\right) \delta 3.71(\mathrm{t}, J=4.7 \mathrm{~Hz}, 6 \mathrm{H}), 3.41(\mathrm{q}, J=7.0 \mathrm{~Hz}, 4 \mathrm{H}), 2.90-2.76(\mathrm{~m}, 4 \mathrm{H}), 2.65-$ $2.55(\mathrm{~m}, 4 \mathrm{H}), 1.92-1.82(\mathrm{~m}, 2 \mathrm{H}), 1.79-1.68(\mathrm{~m}, 2 \mathrm{H}), 1.08(\mathrm{t}, J=7.0 \mathrm{~Hz}, 6 \mathrm{H}) .{ }^{13} \mathrm{C} \mathrm{NMR}\left(\mathrm{CDCl}_{3}\right) \delta 168.9$, $161.7,159.1,133.7,127.4,120.0,66.9,65.0,53.6,44.7,26.6,25.8,23.1,22.9,12.5$.

\section{4-((4-(3-(Trifluoromethyl)phenoxy)-5,6,7,8-tetrahydrobenzo[4,5]thieno[2,3- $d]$ pyrimidin-2-}

yl)methyl)morpholine ${ }^{\mathbf{1 6}}$ (20). A mixture of 4-((4-chloro-5,6,7,8-tetrahydrobenzo[4,5]thieno[2,3d]pyrimidin-2-yl)methyl)morpholine (350 mg, $1.08 \mathrm{mmol})$, 3-(trifluoromethyl)phenol (135 $\mu \mathrm{L}, 1.11 \mathrm{mmol})$, 
$\mathrm{K}_{2} \mathrm{CO}_{3}$ (299 mg, $2.16 \mathrm{mmol}$ ), and tris[2-(2-methoxyethoxy)ethyl]amine (TRIDENT) $(34.0 \mu \mathrm{L}, 108 \mu \mathrm{mol})$ were taken up in $i-\mathrm{PrOH}$ and irradiated at $40 \mathrm{~W}$ for $6 \mathrm{~h}$ in an $8 \mathrm{~mL}$ pressure tube. The reaction mixture was diluted with water, and extracted with DCM. The combined organic extracts were dried and concentrated in vacuo. The residue was chromatographed on silica (1:99 $\mathrm{Et}_{3} \mathrm{~N}$ :EtOAc) to afford the title compound as pale yellow oil (351 mg, 72\%). LCMS (m/z): $450.1[\mathrm{M}+\mathrm{H}]^{+}$. HPLC: $t_{\mathrm{R}} 7.432 \mathrm{~min}$. HRMS $(\mathrm{m} / \mathrm{z}): \mathrm{C}_{22} \mathrm{H}_{22} \mathrm{~F}_{3} \mathrm{~N}_{3} \mathrm{O}_{2} \mathrm{~S}$ requires $450.1468[\mathrm{M}+\mathrm{H}]^{+}$; found 450.1458. ${ }^{1} \mathrm{H} \mathrm{NMR}\left(\mathrm{CDCl}_{3}\right) \delta 7.56-7.48(\mathrm{~m}, 3 \mathrm{H}), 7.41(\mathrm{dt}, J=7.4,1.7$ $\mathrm{Hz}, 1 \mathrm{H}), 3.72-3.60(\mathrm{~m}, 6 \mathrm{H}), 3.04(\mathrm{t}, J=4.8 \mathrm{~Hz}, 2 \mathrm{H}), 2.85(\mathrm{t}, J=4.8 \mathrm{~Hz}, 2 \mathrm{H}), 2.54-2.50(\mathrm{~m}, 4 \mathrm{H}), 1.96-$ $1.85(\mathrm{~m}, 4 \mathrm{H}) .{ }^{13} \mathrm{C} \mathrm{NMR}\left(\mathrm{CDCl}_{3}\right) \delta 169.6,162.2,160.5,152.7,136.2,131.9(\mathrm{q}, J=32.9 \mathrm{~Hz}), 130.0,126.8$, $125.3(\mathrm{~d}, J=0.8 \mathrm{~Hz}), 123.7(\mathrm{q}, J=272.4 \mathrm{~Hz}), 122.0(\mathrm{q}, J=3.8 \mathrm{~Hz}), 119.1(\mathrm{q}, J=3.9 \mathrm{~Hz}), 117.5,66.8,64.3$, $53.6,25.8,25.6,22.9,22.4$.

5,6,7,8-Tetrahydrobenzo[4,5]thieno[2,3- $d]$ pyrimidin-4(3H)-one ${ }^{33} \quad(21) . \quad$ Ethyl-2-amino-4,5,6,7tetrahydrobenzothiophene-3-carboxylate $(4.05 \mathrm{~g}, 17.8 \mathrm{mmol})$ was taken up in formamide $(20 \mathrm{~mL})$ and heated to $170{ }^{\circ} \mathrm{C}$ under a nitrogen atmosphere. The heating was continued for $12 \mathrm{~h}$ and the progress of the reaction was monitored by TLC. The reaction mixture was allowed to cool to r.t., and the precipitated solids were collected and washed with petroleum spirits to afford the compound as brown crystals $(3.12 \mathrm{~g}, 85 \%)$. LCMS $(m / z): 207.1[\mathrm{M}+\mathrm{H}]^{+}$. HPLC: $t_{\mathrm{R}} 5.537 \mathrm{~min}$. HRMS $(\mathrm{m} / z): \mathrm{C}_{10} \mathrm{H}_{10} \mathrm{~N}_{2} \mathrm{OS}$ requires $207.0585[\mathrm{M}+\mathrm{H}]^{+}$; found 207.0587. ${ }^{1} \mathrm{H}$ NMR $\left(d_{6}\right.$-DMSO) $\delta 7.99(\mathrm{~s}, 1 \mathrm{H}), 2.86(\mathrm{t}, J=5.9 \mathrm{~Hz}, 2 \mathrm{H}), 2.73(\mathrm{t}, J=5.8 \mathrm{~Hz}, 2 \mathrm{H}), 1.88-1.64$ $(\mathrm{m}, 4 \mathrm{H}) .{ }^{13} \mathrm{C}$ NMR $\left(d_{6}\right.$-DMSO) $\delta 162.4,157.6,144.8,132.1,130.8,122.6,25.3,24.4,22.4,21.7$.

4-Chloro-5,6,7,8-tetrahydrobenzo[4,5]thieno[2,3- $d]$ pyrimidine (22). General Procedure E. The residue was chromatographed on silica (99:1 EtOAc:Et $\left.{ }_{3} \mathrm{~N}\right)$ which afforded the compound as a gold solid (1.85 g, $68 \%)$. LCMS $(\mathrm{m} / \mathrm{z}): 225.1[\mathrm{M}+\mathrm{H}]^{+} . \mathrm{HPLC}: t_{\mathrm{R}} 8.139 \mathrm{~min} .{ }^{1} \mathrm{H} \mathrm{NMR}\left(\mathrm{CDCl}_{3}\right) \delta 8.70(\mathrm{~s}, 1 \mathrm{H}), 3.09(\mathrm{t}, J=4.3$ $\mathrm{Hz}, 2 \mathrm{H}), 2.88(\mathrm{dd}, J=5.0,3.5 \mathrm{~Hz}, 2 \mathrm{H}), 1.92(\mathrm{dt}, J=6.1,2.9 \mathrm{~Hz}, 4 \mathrm{H}) .{ }^{13} \mathrm{C} \mathrm{NMR}\left(\mathrm{CDCl}_{3}\right) \delta 169.02,153.3$, $151.7,139.7,128.9,127.3,26.4,26.2,22.5,22.3$.

$N$-(3-(Trifluoromethyl)phenyl)-5,6,7,8-tetrahydrobenzo[4,5]thieno[2,3- $d]$ pyrimidin-4-amine

(23a).

General Procedure F. The crude reaction was concentrated under reduced pressure and the residue chromatographed on silica eluting with (1:29:70 $\mathrm{Et}_{3} \mathrm{~N}$ :petroleum ether:EtOAc) to afford the compound as an oil which later solidified under vacuum to give a beige solid $(265 \mathrm{mg}, 68 \%)$. LCMS (m/z): 350.1[M + H $]^{+}$. 
HPLC: $t_{\mathrm{R}} 8.367 \mathrm{~min}$. HRMS $(\mathrm{m} / z): \mathrm{C}_{17} \mathrm{H}_{14} \mathrm{~F}_{3} \mathrm{~N}_{3} \mathrm{~S}$ requires $350.0936[\mathrm{M}+\mathrm{H}]^{+}$; found $350.0933 .{ }^{1} \mathrm{H} \mathrm{NMR}$ $\left(\mathrm{CDCl}_{3}\right) \delta 8.52(\mathrm{~s}, 1 \mathrm{H}), 7.96(\mathrm{~s}, 1 \mathrm{H}), 7.91(\mathrm{~d}, J=8.2 \mathrm{~Hz}, 1 \mathrm{H}), 7.48(\mathrm{t}, J=8.0 \mathrm{~Hz}, 1 \mathrm{H}), 7.36(\mathrm{~d}, J=7.8 \mathrm{~Hz}$, $1 \mathrm{H}), 7.22(\mathrm{~s}, 1 \mathrm{H}), 3.08(\mathrm{t}, J=6.0 \mathrm{~Hz}, 1 \mathrm{H}), 2.86(\mathrm{t}, J=6.0 \mathrm{~Hz}, 1 \mathrm{H}), 2.05-1.91(\mathrm{~m}, 4 \mathrm{H}) .{ }^{13} \mathrm{C} \mathrm{NMR}\left(\mathrm{CDCl}_{3}\right) \delta$ 166.7, 15.6, 152.4, 139.3, 135.5, $131.5(\mathrm{~d}, J=32.4 \mathrm{~Hz}), 129.64,126.1(\mathrm{~d}, J=1.0 \mathrm{~Hz}), 124.1(\mathrm{q}, J=272.5 \mathrm{~Hz})$, $120.3(\mathrm{q}, J=3.8 \mathrm{~Hz}), 117.5(\mathrm{q}, J=3.9 \mathrm{~Hz}), 116.8,26.6,25.6,22.6,22.4$.

$N, N$-Diethyl-5,6,7,8-tetrahydrobenzo[4,5]thieno[2,3- $d]$ pyrimidin-4-amine (23b). General procedure F. The solution was concentrated in vacuo and the residue chromatographed on silica (4:1 EtOAc:petroleum ether) which afforded the desired compound as a light gold oil that solidified under high vacuum to give a pale yellow solid (233 mg, 80\%). $\mathrm{mp}^{\exp }$ : 60-62 ${ }^{\circ} \mathrm{C}$. LCMS $(\mathrm{m} / \mathrm{z}): 262.1[\mathrm{M}+\mathrm{H}]^{+}$. HPLC: $t_{\mathrm{R}} 6.281 \mathrm{~min}$. HRMS $(m / z): \mathrm{C}_{14} \mathrm{H}_{19} \mathrm{~N}_{3} \mathrm{~S}$ requires $262.1376[\mathrm{M}+\mathrm{H}]^{+}$; found 262.1372. ${ }^{1} \mathrm{H} \mathrm{NMR}\left(\mathrm{CDCl}_{3}\right) \delta 8.50(\mathrm{~s}, 1 \mathrm{H}), 3.46(\mathrm{q}, J=$ $7.1 \mathrm{~Hz}, 4 \mathrm{H}), 2.96-2.82(\mathrm{~m}, 4 \mathrm{H}), 1.97-1.90(\mathrm{~m}, 2 \mathrm{H}), 1.84-1.76(\mathrm{~m}, 2 \mathrm{H}), 1.13(\mathrm{t}, J=7.1 \mathrm{~Hz}, 6 \mathrm{H}),) .{ }^{13} \mathrm{C}$ $\operatorname{NMR}\left(\mathrm{CDCl}_{3}\right) \delta 168.3,162.1,151.3,134.2,127.7,122.1,44.9,26.6,25.8,23.0,22.9,12.4$.

\section{2-(Piperidin-1-ylmethyl)-5,6,7,8-tetrahydrobenzo[4,5]thieno[2,3-d]pyrimidin-4(3H)-one (24).}

General procedure D. The reaction mixture was poured into water. The formed precipitates were collected under vacuum filtration and recrystallised from DMF. The mother liquor was extracted with EtOAc, washed with water, brine and the combined organic extracts concentrated in vacuo. The residue was chromatographed on silica (1:99 MeOH:EtOAc) to afford the target compound as cream white solid (350 mg, 73\%), mp: 182$184{ }^{\circ} \mathrm{C} . \mathrm{LCMS}(\mathrm{m} / \mathrm{z}): 304.2[\mathrm{M}+\mathrm{H}]^{+}$. HPLC: $t_{\mathrm{R}} 5.228 \mathrm{~min}$. HRMS $(\mathrm{m} / \mathrm{z}): \mathrm{C}_{16} \mathrm{H}_{21} \mathrm{~N}_{3} \mathrm{OS}$ requires $303.1356[\mathrm{M}$ $+\mathrm{H}]^{+}$; found 303.14. ${ }^{1} \mathrm{H}$ NMR $\delta 9.95(\mathrm{~s}, 1 \mathrm{H}), 3.46(\mathrm{~s}, 2 \mathrm{H}), 3.04-2.97(\mathrm{~m}, 2 \mathrm{H}), 2.77-2.73(\mathrm{~m}, 2 \mathrm{H}), 2.54-$ $2.44(\mathrm{~m}, 4 \mathrm{H}), 1.92-1.78(\mathrm{~m}, 4 \mathrm{H}), 1.62(\mathrm{~m}, 4 \mathrm{H}), 1.48(\mathrm{~d}, J=5.2 \mathrm{~Hz}, 2 \mathrm{H}) .{ }^{13} \mathrm{C} \mathrm{NMR}\left(\mathrm{CDCl}_{3}\right) \delta 163.7,158.3$, $153.8,132.8,131.5,121.9,60.8,54.8,25.9,25.6,25.1,23.7,23.0,22.3$.

\section{4-Chloro-2-(piperidin-1-ylmethyl)-5,6,7,8-tetrahydrobenzo[4,5]thieno[2,3- $d]$ pyrimidine (25).}

General Procedure E. The residue was eluted through a silica gel column (99:1 EtOAc:Et $\left.{ }_{3} \mathrm{~N}\right)$ which proceeded to give the compound as a golden oil $(154 \mathrm{mg}, 41 \%)$. LCMS $(\mathrm{m} / \mathrm{z}): 324.1[\mathrm{M}+\mathrm{H}]^{+}$. HPLC: $t_{\mathrm{R}} 6.231 \mathrm{~min}$. HRMS $(m / z): \mathrm{C}_{16} \mathrm{H}_{20} \mathrm{ClN}_{3} \mathrm{~S}$ requires $322.114[\mathrm{M}+\mathrm{H}]^{+}$; found 322.1139. ${ }^{1} \mathrm{H} \mathrm{NMR}\left(\mathrm{CDCl}_{3}\right) \delta 3.80(\mathrm{~s}, 2 \mathrm{H})$, $3.06(\mathrm{t}, J=4.2 \mathrm{~Hz}, 2 \mathrm{H}), 2.84(\mathrm{t}, J=4.2 \mathrm{~Hz}, 2 \mathrm{H}), 2.52-2.49(\mathrm{~m}, 4 \mathrm{H}), 1.93-1.86(\mathrm{~m}, 4 \mathrm{H}), 1.67-1.57(\mathrm{~m}$, 
4H), $1.49-1.36(\mathrm{~m}, 2 \mathrm{H}) .{ }^{13} \mathrm{C} \mathrm{NMR}\left(\mathrm{CDCl}_{3}\right) \delta 169.4,161.4,152.9,138.9,126.9,126.9,65.2,54.7,26.3,26.0$, $25.7,24.1,22.5,22.2$.

\section{2-(Piperidin-1-ylmethyl)- $N$-(3-(trifluoromethyl)phenyl)-5,6,7,8-tetrahydrobenzo[4,5]thieno[2,3-}

d]pyrimidin-4-amine (26). General Procedure F. This residue was purified on silica gel (99:1 EtOAc:Et $3 \mathrm{~N})$ to give the final product as a yellow oil which later solidified at room temperature (100 mg, 24\%). mp: 121 $126^{\circ} \mathrm{C}$. LCMS $(\mathrm{m} / \mathrm{z}): 447.3[\mathrm{M}+\mathrm{H}]^{+}$. HPLC: $t_{\mathrm{R}} 7.602 \mathrm{~min}$. HRMS $(\mathrm{m} / \mathrm{z}): \mathrm{C}_{23} \mathrm{H}_{25} \mathrm{~F}_{3} \mathrm{~N}_{4} \mathrm{~S}$ requires $447.1828[\mathrm{M}$ $+\mathrm{H}]^{+}$; found $447.1825 .{ }^{1} \mathrm{H}$ NMR $\delta 8.17(\mathrm{~s}, 1 \mathrm{H}), 7.93(\mathrm{dd}, J=8.1,1.6 \mathrm{~Hz}, 1 \mathrm{H}), 7.48(\mathrm{t}, J=8.0 \mathrm{~Hz}, 1 \mathrm{H}), 7.34$ $-7.31(\mathrm{~d}, J=7.7 \mathrm{~Hz}, 1 \mathrm{H}), 7.26(\mathrm{~s}, 1 \mathrm{H}), 3.77(\mathrm{~s}, 2 \mathrm{H}), 3.09(\mathrm{t}, J=6.0 \mathrm{~Hz}, 2 \mathrm{H}), 2.87(\mathrm{t}, J=6.0 \mathrm{~Hz}, 2 \mathrm{H}), 2.58(\mathrm{~s}$, 4H), $2.04-1.97(\mathrm{~m}), 1.98-1.94(\mathrm{~m}, 2 \mathrm{H}), 1.66(\mathrm{dt}, J=11.2,5.6 \mathrm{~Hz}, 4 \mathrm{H}), 1.48-1.39(\mathrm{~m}, 2 \mathrm{H}) .{ }^{13} \mathrm{C}$ NMR $\left(\mathrm{CDCl}_{3}\right) \delta 167.5,161.4,154.2,139.7,135.0,131.4(\mathrm{q}, J=32.3 \mathrm{~Hz}), 129.5,124.2,124.1(\mathrm{q}, J=272.4 \mathrm{~Hz})$, $123.2,119.7(\mathrm{q}, J=3.8 \mathrm{~Hz}), 117.1(\mathrm{q}, J=4.0 \mathrm{~Hz}), 115.1,65.8,54.8,26.6,26.0,25.7,24.3,22.7,22.5$.

2-(Tetrahydro-4H-pyran-4-ylidene)acetonitrile ${ }^{35}$ (29). To a suspension of sodium hydride (60\% mineral dispersion oil) $(2.37 \mathrm{~g}, 59.3 \mathrm{mmol})$ in diethyl ether $(150 \mathrm{~mL})$ cooled to $0{ }^{\circ} \mathrm{C}$ was added diethyl cyanomethylphosphonate $(9.55 \mathrm{~mL}, 59.3 \mathrm{mmol})$ dropwise followed by a solution of tetrahydro- $4 H$-pyran-4one $(5.00 \mathrm{~mL}, 53.9 \mathrm{mmol})$ in diethyl ether $(150 \mathrm{~mL})$. After the addition was completed the reaction was warmed to room temperature and stirred overnight. $\mathrm{H}_{2} \mathrm{O}$ and EtOAc were added, the organic layer was separated, washed with brine, dried over $\mathrm{Na}_{2} \mathrm{SO}_{4}$, filtered and concentrated in vacuo to provide the compound as a brown oil. The crude oil was then subjected to vacuum distillation (20 mbar) to reveal the title compound as a transparent oil which crystallised upon standing. This distillate was dissolved in hot petroleum ether and left in the fridge overnight to recrystallise. The crystals were collected and dried to afford the desired compound as a white crystalline solid (2.56 g, 39\%). LCMS (m/z): $124.2[\mathrm{M}+\mathrm{H}]^{+}$. HPLC: $t_{\mathrm{R}} 3.390 \mathrm{~min} .{ }^{1} \mathrm{H}$ $\mathrm{NMR}\left(\mathrm{CDCl}_{3}\right) \delta 5.19-5.16(\mathrm{~m}, 1 \mathrm{H}), 3.81-3.71(\mathrm{~m}, 4 \mathrm{H}), 2.67-2.60(\mathrm{~m}, 2 \mathrm{H}), 2.43-2.37(\mathrm{~m}, 2 \mathrm{H}) .{ }^{13} \mathrm{C} \mathrm{NMR}$ $\left(\mathrm{CDCl}_{3}\right) \delta 162.7,116.2,93.6,68.3,68.1,35.9,33.7$.

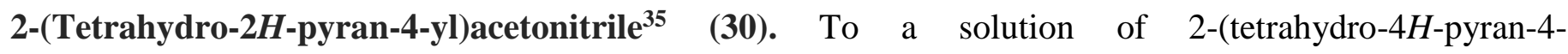
ylidene)acetonitrile $(2.65 \mathrm{~g}, 20.8 \mathrm{mmol})$, in ethyl acetate $(25 \mathrm{~mL})$ \& acetic acid $(1 \mathrm{~mL})$, stirred under $\mathrm{N}_{2}$ was added 10\% $\mathrm{Pd} / \mathrm{C}$ (84.0 mg, $4.17 \mathrm{mmol})$. The reaction mixture was evacuated under reduced pressure, purged with hydrogen and stirred for $5 \mathrm{~h}$ at $\mathrm{rt}$ under $1 \mathrm{~atm}$ of pressure. TLC showed consumption of the starting 
material after 5 hours. The reaction was filtered $\left(\right.$ Celite $\left.^{\circledR}\right)$ and the filtrate was concentrated in vacuo to provide the compound as pale yellow oil which was used for the next reaction without any further purification (2.61 g, quantitative yield). ${ }^{1} \mathrm{H} \mathrm{NMR}\left(\mathrm{CDCl}_{3}\right) \delta 4.04-3.98(\mathrm{~m}, 2 \mathrm{H}), 3.40(\mathrm{td}, J=11.9,2.1 \mathrm{~Hz}, 2 \mathrm{H}), 2.32(\mathrm{~d}, J=6.8$ $\mathrm{Hz}, 2 \mathrm{H}), 1.93$ (qdd, $J=10.8,7.0,3.9 \mathrm{~Hz}, 2 \mathrm{H}), 1.75$ (ddd, $J=12.6,3.5,1.6 \mathrm{~Hz}, 2 \mathrm{H}), 1.51-1.38(\mathrm{~m}, 2 \mathrm{H}) .{ }^{13} \mathrm{C}$ $\operatorname{NMR}\left(\mathrm{CDCl}_{3}\right) \delta 118.1,67.3,32.3,32.1,24.4$.

\section{2-((Tetrahydro-2H-pyran-4-yl)methyl)-5,6,7,8-tetrahydrobenzo[4,5]thieno[2,3-d]pyrimidin-4(3H)-one}

(31). General Procedure C. The reaction mixture was filtered directly and the solid washed with petroleum ether to obtain the desired compound as a beige solid (4.23 g, 93\%). mp: $250-252{ }^{\circ} \mathrm{C}$. LCMS (m/z): 255.1 [M $+\mathrm{H}]^{+}$. HPLC: $t_{\mathrm{R}} 6.858 \mathrm{~min}$. HRMS $(\mathrm{m} / \mathrm{z}): \mathrm{C}_{11} \mathrm{H}_{11} \mathrm{ClN}_{2} \mathrm{OS}$ requires $255.0354[\mathrm{M}+\mathrm{H}]^{+}$; found $255.0353 .{ }^{1} \mathrm{H}$ NMR (d6-DMSO) $\delta 7.44(\mathrm{~s}, 1 \mathrm{H}), 4.56(\mathrm{~s}, 2 \mathrm{H}), 2.85(\mathrm{t}, J=5.8 \mathrm{~Hz}, 2 \mathrm{H}), 2.73(\mathrm{t}, J=5.8 \mathrm{~Hz}, 2 \mathrm{H}), 1.76(\mathrm{ddd}, J$ $=7.5,6.8,4.4 \mathrm{~Hz}, 4 \mathrm{H}) .{ }^{13} \mathrm{C}$ NMR $\left(d_{6}\right.$-DMSO) $\delta 163.1,158.5,156.0,131.0,130.5,120.4,66.8,40.8,33.8$, $32.2,25.3,24.4,22.5,21.8$.

4-Chloro-2-((tetrahydro-2H-pyran-4-yl)methyl)-5,6,7,8-tetrahydrobenzo[4,5] thieno[2,3- $d]$ pyrimidine (32). General Procedure E. The residue was chromatographed on silica (1:99 Et $3 \mathrm{~N}$ :EtOAc) to afford the compound as a gold oil $(350 \mathrm{mg}, 24 \%)$. LCMS $(\mathrm{m} / z): 323.2[\mathrm{M}+\mathrm{H}]^{+}$. HPLC: $t_{\mathrm{R}} 9.066 \mathrm{~min},>95 \%$ purity $(254$ nm). ${ }^{1} \mathrm{H}$ NMR $\left(\mathrm{CDCl}_{3}\right) \delta 3.93(\mathrm{dd}, J=11.5,2.4 \mathrm{~Hz}, 2 \mathrm{H}), 3.38(\mathrm{td}, J=11.7,2.3 \mathrm{~Hz}, 2 \mathrm{H}), 3.06(\mathrm{~d}, J=2.1 \mathrm{~Hz}$, 2H), $2.91(\mathrm{~d}, J=7.2 \mathrm{~Hz}, 2 \mathrm{H}), 2.85(\mathrm{~d}, J=2.1 \mathrm{~Hz}, 2 \mathrm{H}), 2.28-2.17(\mathrm{~m}, 1 \mathrm{H}), 1.90(\mathrm{dt}, J=6.0,2.9 \mathrm{~Hz}, 4 \mathrm{H})$, $1.60-1.52(\mathrm{~m}, 2 \mathrm{H}), 1.51-1.39(\mathrm{~m}, 2 \mathrm{H}) .{ }^{13} \mathrm{C} \mathrm{NMR}\left(\mathrm{CDCl}_{3}\right) \delta 169.3,163.4,152.9,138.2,126.9,126.3,67.8$, $45.7,35.1,32.8,26.3,25.9,22.5,22.3$.

2-((Tetrahydro-2H-pyran-4-yl)methyl)- $N$-(3-(trifluoromethyl)phenyl)-5,6,7,8-

tetrahydrobenzo[4,5] thieno[2,3-d]pyrimidin-4-amine (33a). General Procdedure F. The crude reaction mixture was evaporated under reduced pressure and the residue chromatographed on silica $(1 \% \mathrm{MeOH}-$ $\left.\mathrm{CHCl}_{3}\right)$ which furnished the title compound as a white foam $(160 \mathrm{mg}, 48 \%)$. LCMS $(\mathrm{m} / \mathrm{z}): 448.2[\mathrm{M}+\mathrm{H}]^{+}$. HPLC: $t_{\mathrm{R}} 7.945$ min. HRMS $(m / z): \mathrm{C}_{23} \mathrm{H}_{24} \mathrm{~F}_{3} \mathrm{~N}_{3} \mathrm{OS}$ requires $448.1673[\mathrm{M}+\mathrm{H}]^{+}$; found 448.1665. ${ }^{1} \mathrm{H}$ NMR $\left(\mathrm{CDCl}_{3}\right) \delta 8.31(\mathrm{~s}, 1 \mathrm{H}), 7.72(\mathrm{dd}, J=8.1,1.7 \mathrm{~Hz}, 1 \mathrm{H}), 7.47(\mathrm{t}, J=7.9 \mathrm{~Hz}, 1 \mathrm{H}), 7.36-7.33(\mathrm{~m}, 1 \mathrm{H}), 7.24(\mathrm{~s}$, $1 \mathrm{H}), 3.95(\mathrm{dd}, J=11.5,2.4 \mathrm{~Hz}, 2 \mathrm{H}), 3.41(\mathrm{td}, J=11.8,2.1 \mathrm{~Hz}, 2 \mathrm{H}), 3.07(\mathrm{t}, J=6.0 \mathrm{~Hz}, 2 \mathrm{H}), 2.84(\mathrm{dd}, J=$ 13.1, $6.7 \mathrm{~Hz}, 4 \mathrm{H}), 2.26(\mathrm{dqd}, J=15.1,7.5,3.7 \mathrm{~Hz}, 1 \mathrm{H}), 2.03-1.90(\mathrm{~m}, 4 \mathrm{H}), 1.63(\mathrm{dd}, J=13.0,1.9 \mathrm{~Hz}, 2 \mathrm{H})$, 
$1.52-1.43(\mathrm{~m}, 2 \mathrm{H}) .{ }^{13} \mathrm{C} \mathrm{NMR}\left(\mathrm{CDCl}_{3}\right) \delta 167.3,163.4,154.2,139.5,134.3,131.3,(\mathrm{q}, J=32.2 \mathrm{~Hz}), 124.3$, 124.1, (q, $J=272.5 \mathrm{~Hz}) 123.0,119.7,(\mathrm{q}, J=3.8 \mathrm{~Hz}), 117.2,(\mathrm{q}, J=4.0 \mathrm{~Hz}), 114.5,67.9,46.2,34.9,32.9$, $26.5,25.5,22.6,22.5$.

\section{$N, N$-Diethyl-2-((tetrahydro-2H-pyran-4-yl)methyl)-5,6,7,8-tetrahydrobenzo[4,5]thieno[2,3-}

d]pyrimidin-4-amine (33b). General procedure F. Chromatographed on silica (50:50 petroleum ether:EtOAc) furnishing the target compound as a gold oil $\left(150 \mathrm{mg}\right.$, quantitative yield). LCMS $(\mathrm{m} / \mathrm{z}): 360.2[\mathrm{M}+\mathrm{H}]^{+}$. HPLC: $t_{\mathrm{R}} 6.664 \mathrm{~min}$. HRMS $(\mathrm{m} / z): \mathrm{C}_{20} \mathrm{H}_{29} \mathrm{~N}_{3} \mathrm{OS}$ requires $360.2107[\mathrm{M}+\mathrm{H}]^{+}$; found $360.2104 .{ }^{1} \mathrm{H}$ NMR $\left(\mathrm{CDCl}_{3}\right) \delta 3.94(\mathrm{dd}, J=11.4,2.4 \mathrm{~Hz}, 2 \mathrm{H}), 3.44(\mathrm{dd}, J=14.1,7.1 \mathrm{~Hz},(\mathrm{~m}, 4 \mathrm{H}), 3.42-3.34(\mathrm{~m}, 2 \mathrm{H}), 2.89(\mathrm{t}, J$ $=5.9 \mathrm{~Hz}, 2 \mathrm{H}), 2.84(\mathrm{t}, J=6.3 \mathrm{~Hz}, 2 \mathrm{H}), 2.79(\mathrm{~d}, J=7.2 \mathrm{~Hz}, 2 \mathrm{H}), 2.27-2.15(\mathrm{~m}, 1 \mathrm{H}), 1.96-1.88(\mathrm{~m}, 2 \mathrm{H})$, $1.81-1.74(\mathrm{~m}, 2 \mathrm{H}), 1.59(\mathrm{dd}, J=13.0,1.7 \mathrm{~Hz}, 2 \mathrm{H}), 1.44(\mathrm{ddd}, J=11.9,10.3,6.0 \mathrm{~Hz}, \mathrm{~m}, 2 \mathrm{H}), 1.12(\mathrm{t}, J=7.0$ $\mathrm{Hz}, 6 \mathrm{H}) .{ }^{13} \mathrm{C} \mathrm{NMR}\left(\mathrm{CDCl}_{3}\right) \delta 168.9,162.0,161.9,132.9,127.6,119.6,68.1,45.9,44.9,34.9,33.0,26.7,25.8$, $23.1,23.0,12.5$.

4-Morpholinobutanenitrile ${ }^{\mathbf{3 6}} \mathbf{( 3 5 b )}$. Morpholine (3.66 mL, $\left.42.3 \mathrm{mmol}\right)$ and 4-chlorobutanenitrile (2.00 $\mathrm{mL}$, $21.6 \mathrm{mmol})$ were taken up in toluene $(30 \mathrm{~mL})$ and stirred at reflux temperature for $7 \mathrm{~h}$. The reaction mixture was filtered directly and the solids washed with $\mathrm{CH}_{2} \mathrm{Cl}_{2}$. The filtrate was acidified with $1 \mathrm{M} \mathrm{KHSO}_{4}$ solution and extracted with further $\mathrm{CH}_{2} \mathrm{Cl}_{2}$, and the organic extracts were discarded. The aqueous phase was then adjusted to $\mathrm{pH} 12$ with $1 \mathrm{M} \mathrm{NaOH}$ and extracted with $\mathrm{CH}_{2} \mathrm{Cl}_{2}(3 \times 25 \mathrm{~mL})$. The organic extracts were dried over anhydrous $\mathrm{Na}_{2} \mathrm{SO}_{4}$, and concentrated in vacuo to yield the compound as a transparent oil which was utilised without further purification $(2.12 \mathrm{~g}, 65 \%)$. LCMS $(\mathrm{m} / \mathrm{z}): 155.1[\mathrm{M}+\mathrm{H}]^{+} .{ }^{1} \mathrm{H} \mathrm{NMR}\left(\mathrm{CDCl}_{3}\right) \delta 3.77-$ $3.66(\mathrm{~m}, 4 \mathrm{H}), 2.53-2.37(\mathrm{~m}, 8 \mathrm{H}), 1.83(\mathrm{p}, J=6.9 \mathrm{~Hz}, 2 \mathrm{H}) .{ }^{13} \mathrm{C} \mathrm{NMR}\left(\mathrm{CDCl}_{3}\right) \delta 119.8,66.9,56.7,53.5,22.5$, 14.9.

5-Morpholinopentanenitrile $\mathbf{3 6}^{\mathbf{3 6}}$ (35). Morpholine (6.93 mL, $\left.80.4 \mathrm{mmol}\right)$ and 5-chlorovaleronitrile (4.50 $\mathrm{mL}$, $40.2 \mathrm{mmol})$ were taken up in toluene $(50 \mathrm{~mL})$ and stirred at reflux temperature for $8 \mathrm{~h}$. The reaction mixture was filtered directly and the solids washed with $\mathrm{CH}_{2} \mathrm{Cl}_{2}$. The filtrate was acidified with $1 \mathrm{M} \mathrm{KHSO}$ solution and extracted with further $\mathrm{CH}_{2} \mathrm{Cl}_{2}$, and the organic extracts were discarded. The aqueous phase was then adjusted to pH 12 with $1 \mathrm{M} \mathrm{NaOH}$ and extracted with $\mathrm{CH}_{2} \mathrm{Cl}_{2}(3 \times 30 \mathrm{~mL})$. The organic extracts were dried over anhydrous $\mathrm{Na}_{2} \mathrm{SO}_{4}$, and concentrated in vacuo to yield the compound as a transparent oil which was 
utilised without further purification $(2.93 \mathrm{~g}, 43 \%)$. LCMS $(\mathrm{m} / \mathrm{z}): 169.2[\mathrm{M}+\mathrm{H}]^{+} .{ }^{1} \mathrm{H} \mathrm{NMR}\left(\mathrm{CDCl}_{3}\right) \delta 3.77-$ $3.61(\mathrm{~m}, 4 \mathrm{H}), 2.52-2.29(\mathrm{~m}, 8 \mathrm{H}), 1.80-1.57(\mathrm{~m}, 4 \mathrm{H}) .{ }^{13} \mathrm{C} \mathrm{NMR}\left(\mathrm{CDCl}_{3}\right) \delta 119.7,67.0,57.8,53.7,25.4$, 23.4, 17.1.

2-(2-Chloroethyl)-5,6,7,8-tetrahydrobenzo[4,5]thieno[2,3- $d]$ pyrimidin-4(3H)-one $\quad$ (36a). General procedure C. The reaction was allowed to cool and the precipitate was collected, washed with cold 1,4dioxane, triturated with petroleum ether, filtered and dried to afford the compound as a beige powder (4.95 g, $83 \%) . \operatorname{LCMS}(\mathrm{m} / z): 269.1[\mathrm{M}+\mathrm{H}]^{+} . \mathrm{HPLC}: t_{\mathrm{R}} 6.677 \mathrm{~min} .{ }^{1} \mathrm{H}$ NMR $\left(d_{6}-\mathrm{DMSO}\right) \delta 12.38(\mathrm{~s}, 1 \mathrm{H}), 3.98(\mathrm{t}, J=$ $6.6 \mathrm{~Hz}, 2 \mathrm{H}), 3.09(\mathrm{t}, J=6.6 \mathrm{~Hz}, 2 \mathrm{H}), 2.84(\mathrm{t}, J=5.8 \mathrm{~Hz}, 2 \mathrm{H}), 2.71(\mathrm{t}, J=5.8 \mathrm{~Hz}, 2 \mathrm{H}), 1.83-1.67(\mathrm{~m}, 4 \mathrm{H})$. ${ }^{13} \mathrm{C}$ NMR $\left(d_{6}\right.$-DMSO) $\delta 162.6,158.4,154.2,131.6,130.7,120.8,41.5,36.6,25.3,24.4,22.5,21.8$.

2-(3-Chloropropyl)-5,6,7,8-tetrahydrobenzo[4,5]thieno[2,3-d]pyrimidin-4(3H)-one $\quad(36 b)$ General procedure C. The reaction mixture was allowed to cool and the formed precipitate was collected and washed with cold 1,4-dioxane to yield a light brown solid $(3.16 \mathrm{~g}, 60 \%)$. LCMS $(\mathrm{m} / z): 283.1[\mathrm{M}+\mathrm{H}]^{+}$. HPLC: $t_{\mathrm{R}}$ 7.018 min. ${ }^{1} \mathrm{H}$ NMR $\left(d_{6}\right.$-DMSO) $\delta 12.29(\mathrm{~s}, 1 \mathrm{H}), 3.70(\mathrm{t}, J=6.5 \mathrm{~Hz}, 1 \mathrm{H}), 2.85(\mathrm{t}, J=5.8 \mathrm{~Hz}, 2 \mathrm{H}), 2.78-2.73$ $(\mathrm{m}, 2 \mathrm{H}), 2.73-2.68(\mathrm{~m}, 2 \mathrm{H}), 2.15(\mathrm{dq}, J=13.6,6.6 \mathrm{~Hz}, 2 \mathrm{H}), 1.77(\mathrm{ddt}, J=8.6,5.2,2.6 \mathrm{~Hz}, 4 \mathrm{H}) .{ }^{13} \mathrm{C} \mathrm{NMR}$ (d6-DMSO) $\delta 162.6,158.5,156.4,131.2,130.6,120.6,44.6,30.9,29.3,25.3,24.4,22.5,21.8$.

2-(4-Chlorobutyl)-5,6,7,8-tetrahydrobenzo[4,5]thieno[2,3- $d]$ pyrimidin-4(3H)-one $(36 \mathrm{c})$. The reaction mixture was allowed to cool and water $(150 \mathrm{~mL})$ was added. The precipitate was collected, washed with $\mathrm{MeOH}$, and recrystallised from DMF to afford the compound as light brown crystals $(6.56 \mathrm{~g}, 83 \%$ yield). LCMS (m/z): $297.1[\mathrm{M}+\mathrm{H}]^{+}$. HPLC: $t_{\mathrm{R}} 7.276 \mathrm{~min} .{ }^{1} \mathrm{H}$ NMR $\left(d_{6}-\mathrm{DMSO}\right) \delta 12.22(\mathrm{~s}, 1 \mathrm{H}), 3.66(\mathrm{t}, J=6.3 \mathrm{~Hz}$, 2H), $2.85(\mathrm{t}, J=6.0 \mathrm{~Hz}, 2 \mathrm{H}), 2.71(\mathrm{t}, J=5.8 \mathrm{~Hz}, 2 \mathrm{H}), 2.61(\mathrm{t}, J=7.2 \mathrm{~Hz}, 2 \mathrm{H}), 1.86-1.68(\mathrm{~m}, 8 \mathrm{H}) .{ }^{13} \mathrm{C} \mathrm{NMR}$ (d6-DMSO) $\delta 163.1,158.5,157.0,131.2,130.5,120.4,45.0,32.9,31.3,25.2,24.4,24.1,22.5,21.8$.

2-(2-Morpholinoethyl)-5,6,7,8-tetrahydrobenzo[4,5]thieno[2,3- $d]$ pyrimidin-4(3H)-one (37a). General Procedure D. Residue chromatographed on silica (1:99 $\left.\mathrm{Et}_{3} \mathrm{~N}: \mathrm{EtOAc}\right)$ to yield the compound as a white solid (800 mg, 56\%). LCMS (m/z): $320.1[\mathrm{M}+\mathrm{H}]^{+}$. HPLC: $t_{\mathrm{R}} 4.909 \mathrm{~min}$. HRMS $(\mathrm{m} / \mathrm{z}): \mathrm{C}_{16} \mathrm{H}_{21} \mathrm{~N}_{3} \mathrm{O}_{2} \mathrm{~S}$ requires $320.1433[\mathrm{M}+\mathrm{H}]^{+}$; found 320.1427. ${ }^{1} \mathrm{H} \mathrm{NMR}\left(\mathrm{CDCl}_{3}\right) \delta 12.51(\mathrm{~s}, 1 \mathrm{H}), 3.82-3.71(\mathrm{~m}, 4 \mathrm{H}), 2.96(\mathrm{t}, J=5.9$ $\mathrm{Hz}, 2 \mathrm{H}), 2.89-2.83(\mathrm{~m}, 2 \mathrm{H}), 2.84-2.78(\mathrm{~m}, 2 \mathrm{H}), 2.74(\mathrm{t}, J=5.9 \mathrm{~Hz}, 2 \mathrm{H}), 2.62-2.56(\mathrm{q}, J=3.8 \mathrm{~Hz}, 4 \mathrm{H})$, 
$1.90-1.73(\mathrm{~m}, 4 \mathrm{H}) .{ }^{13} \mathrm{C} \mathrm{NMR}\left(\mathrm{CDCl}_{3}\right) \delta 163.9,159.7,155.6,132.6,131.3,121.4,66.9,55.7,53.2,30.1,25.6$, $25.2,23.1,22.4$.

2-(3-Morpholinopropyl)-5,6,7,8-tetrahydrobenzo[4,5]thieno[2,3- $d]$ pyrimidin-4(3H)-one $\mathrm{e}^{37}$

(37b).

General Procedure C. The reaction mixture was filtered directly and the solids washed with petroleum ether to obtain the desired compound as a fluffy beige solid $(3.51 \mathrm{~g}, 80 \%)$. LCMS $(\mathrm{m} / z): 334.1[\mathrm{M}+\mathrm{H}]^{+}$. HPLC: $t_{\mathrm{R}}$ 4.925 min. HRMS $(m / z): \mathrm{C}_{17} \mathrm{H}_{23} \mathrm{~N}_{3} \mathrm{O}_{2} \mathrm{~S}$ requires $334.1586[\mathrm{M}+\mathrm{H}]^{+}$; found 334.1584. ${ }^{1} \mathrm{H}$ NMR $\left(d_{6}\right.$-DMSO) $\delta$ $11.54(\mathrm{~s}, 1 \mathrm{H}), 3.99-3.81(\mathrm{~m}, 4 \mathrm{H}), 3.42(\mathrm{~d}, J=12.3 \mathrm{~Hz}, 2 \mathrm{H}), 3.15-3.07(\mathrm{~m}, 2 \mathrm{H}), 3.06-3.01(\mathrm{~m}, 2 \mathrm{H}), 2.85$ $(\mathrm{t}, J=5.5 \mathrm{~Hz}, 2 \mathrm{H}), 2.70(\mathrm{t}, J=7.2 \mathrm{~Hz}, 4 \mathrm{H}), 2.17(\mathrm{dq}, J=15.4,7.6 \mathrm{~Hz}, 2 \mathrm{H}), 1.86-1.69(\mathrm{~m}, 4 \mathrm{H}) .{ }^{13} \mathrm{C} \mathrm{NMR}$ $\left(d_{6}\right.$-DMSO) $\delta 162.9,158.9,156.5,131.7,131.0,121.1,63.5,55.5,51.3,31.2,25.7,24.9,22.9,22.2,20.8$.

2-(4-Morpholinobutyl)-5,6,7,8-tetrahydrobenzo[4,5]thieno[2,3- $d]$ pyrimidin-4(3H)-one $(37 \mathrm{c})$. General

Procedure $\mathrm{C}$. The reaction mixture was filtered directly and the solids collected and washed with hot $i$-PrOH to afford the desired compound as a white solid $(2.34 \mathrm{~g}, 57 \%)$. LCMS $(\mathrm{m} / \mathrm{z}): 348.2[\mathrm{M}+\mathrm{H}]^{+}$. HPLC: $t_{\mathrm{R}} 5.034$ $\min$. HRMS $(m / z): \mathrm{C}_{18} \mathrm{H}_{25} \mathrm{~N}_{3} \mathrm{O}_{2} \mathrm{~S}$ requires $348.1749[\mathrm{M}+\mathrm{H}]^{+}$; found 348.1740. ${ }^{1} \mathrm{H}$ NMR $\left(d_{6}-\mathrm{DMSO}\right) \delta 11.36$ (s, 1H), $3.99-3.77(\mathrm{~m}, 4 \mathrm{H}), 3.36(\mathrm{~d}, J=12.2 \mathrm{~Hz}, 2 \mathrm{H}), 3.13-2.93(\mathrm{~m}, 2 \mathrm{H}), 2.83(\mathrm{t}, J=5.6 \mathrm{~Hz}, 2 \mathrm{H}), 2.70(\mathrm{t}$, $J=5.5 \mathrm{~Hz}, 2 \mathrm{H}), 2.64(\mathrm{t}, J=6.8 \mathrm{~Hz}, 2 \mathrm{H}), 1.86-1.63(\mathrm{~m}, 8 \mathrm{H}) .{ }^{13} \mathrm{C} \mathrm{NMR}\left(d_{6}\right.$-DMSO) $\delta 162.6,158.5,157.1$, $131.3,130.7,120.6,63.2,55.5,50.9,33.1,25.4,24.5,24.0,22.6,22.1,21.9$.

4-(2-(4-Chloro-5,6,7,8-tetrahydrobenzo[4,5] thieno[2,3- $d]$ pyrimidin-2-yl)ethyl)morpholine (38a).

General Procedure E. The residue was chromatographed on silica (1:99 Et 3 N:EtOAc) to afford the compound as a gold oil $(270 \mathrm{mg}, 78 \%)$. LCMS $(\mathrm{m} / \mathrm{z}): 338.1[\mathrm{M}+\mathrm{H}]^{+}$. HPLC: $t_{\mathrm{R}} 5.824 \mathrm{~min} .{ }^{1} \mathrm{H} \mathrm{NMR}\left(\mathrm{CDCl}_{3}\right) \delta 3.87-$ $3.52(\mathrm{~m}, 4 \mathrm{H}), 3.29-3.12(\mathrm{~m}, 2 \mathrm{H}), 3.05(\mathrm{~s}, 2 \mathrm{H}), 2.98-2.89(\mathrm{~m}, 2 \mathrm{H}), 2.85(\mathrm{~s}, 2 \mathrm{H}), 2.59-2.50(\mathrm{~m}, 4 \mathrm{H}), 1.94$ - $1.84(\mathrm{~m}, 4 \mathrm{H}) .{ }^{13} \mathrm{C} \mathrm{NMR}\left(\mathrm{CDCl}_{3}\right) \delta 169.4,163.3,152.9,138.1,126.9,126.4,67.0,57.2,53.4,35.9,26.3$, $25.9,22.5,22.3$.

\section{4-(3-(4-Chloro-5,6,7,8-tetrahydrobenzo[4,5] thieno[2,3-d]pyrimidin-2-yl)propyl)morpholine}

(38b).

General Procedure E. The residue was chromatographed on silica (1:99 Et $3 \mathrm{~N}$ :EtOAc) to afford the compound as a gold oil $(1.06 \mathrm{~g}, 67 \%)$. LCMS $(\mathrm{m} / \mathrm{z}): 352.1[\mathrm{M}+\mathrm{H}]^{+}$. HPLC: $t_{\mathrm{R}} 5.938 \mathrm{~min} .{ }^{1} \mathrm{H}$ NMR $\left(\mathrm{CDCl}_{3}\right) \delta 3.66-$ $3.61(\mathrm{~m}, 4 \mathrm{H}), 3.08-2.95(\mathrm{~m}, 4 \mathrm{H}), 2.88-2.78(\mathrm{~m}, 2 \mathrm{H}), 2.47-2.37(\mathrm{~m}, 4 \mathrm{H}), 2.11-2.00(\mathrm{~m}, 2 \mathrm{H}), 1.91(\mathrm{dt}, J$ 
$=6.0,2.9 \mathrm{~Hz}, 4 \mathrm{H}) .{ }^{13} \mathrm{C} \mathrm{NMR}\left(\mathrm{CDCl}_{3}\right) \delta 169.4,164.8,152.8,137.9,126.9,126.2,66.9,58.4,53.6,26.3,25.9$, $25.4,22.5,22.2$.

\section{4-(4-(4-Chloro-5,6,7,8-tetrahydrobenzo[4,5] thieno[2,3- $d]$ pyrimidin-2-yl)butyl)morpholine (38c).}

General Procedure E. The residue was chromatographed on silica (1:99 $\mathrm{Et}_{3} \mathrm{~N}$ :EtOAc) to afford the compound as a gold oil $(1.42 \mathrm{~g}, 88 \%)$. LCMS $(\mathrm{m} / z): 366.1[\mathrm{M}+\mathrm{H}]^{+}$. HPLC: $t_{\mathrm{R}} 6.255 \mathrm{~min} .{ }^{1} \mathrm{H}$ NMR $\left(\mathrm{CDCl}_{3}\right) \delta 3.75-$ $3.63(\mathrm{~m}, 4 \mathrm{H}), 3.07-3.02(\mathrm{~m}, 2 \mathrm{H}), 3.02-2.97(\mathrm{~m}, 2 \mathrm{H}), 2.87-2.82(\mathrm{~m}, 2 \mathrm{H}), 2.44-2.34(\mathrm{~m}, 6 \mathrm{H}), 1.98-1.79$ $(\mathrm{m}, 6 \mathrm{H}), 1.62-1.53(\mathrm{~m}, 2 \mathrm{H}) .{ }^{13} \mathrm{C} \mathrm{NMR}\left(\mathrm{CDCl}_{3}\right) \delta 169.4,164.9,152.9,138.0,126.9,126.2,66.9,58.7,53.7$, $26.5,26.2,26.2,25.9,22.5,22.2$.

\section{2-(2-Morpholinoethyl)- $N$-(3-(trifluoromethyl)phenyl)-5,6,7,8-tetrahydrobenzo[4,5]thieno[2,3-}

d]pyrimidin-4-amine (39a). General Procedure F. The crude reaction mixture was concentrated under reduced pressure and the residue chromatographed on silica (1:99 $\left.\mathrm{Et}_{3} \mathrm{~N}: \mathrm{EtOAc}\right)$. The product was isolated and found to have co-eluted with a reaction by-product $\left(\mathrm{m} / \mathrm{z}: 347.2[\mathrm{M}+\mathrm{H}]^{+}\right)$, this mixture was concentrated under reduced pressure, and the resulting bright yellow solid was suspended in $\mathrm{Et}_{2} \mathrm{O}$. The solids were collected under vacuum filtration \& washed with $\mathrm{Et}_{2} \mathrm{O}$ to afford the desired compound as pale yellow crystalline solid (233 mg, 27\%). LCMS (m/z): $463.2[\mathrm{M}+\mathrm{H}]^{+}$. HPLC: $t_{\mathrm{R}} 7.025 \mathrm{~min}$. HRMS $(\mathrm{m} / \mathrm{z}): \mathrm{C}_{23} \mathrm{H}_{25} \mathrm{~F}_{3} \mathrm{~N}_{4} \mathrm{O}$ requires 463.1783 $[\mathrm{M}+\mathrm{H}]^{+}$; found 463.1774. ${ }^{1} \mathrm{H}$ NMR $\left(\mathrm{CDCl}_{3}\right) \delta 8.28(\mathrm{~s}, 1 \mathrm{H}), 7.71(\mathrm{dd}, J=7.9,1.5 \mathrm{~Hz}, 1 \mathrm{H}), 7.44(\mathrm{t}, J=7.9$ $\mathrm{Hz}, 1 \mathrm{H}), 7.35-7.31(\mathrm{~m}, 1 \mathrm{H}), 7.23(\mathrm{~s}, 1 \mathrm{H}), 3.87-3.60(\mathrm{~m}, 2 \mathrm{H}), 3.12-3.04(\mathrm{~m}, 4 \mathrm{H}), 2.97-2.91(\mathrm{~m}, 2 \mathrm{H})$, $2.84(\mathrm{t}, J=6.0 \mathrm{~Hz}, 2 \mathrm{H}), 2.59-2.49(\mathrm{~m}, 4 \mathrm{H}), 2.07-1.89(\mathrm{~m}, 4 \mathrm{H}) .{ }^{13} \mathrm{C} \mathrm{NMR}\left(\mathrm{CDCl}_{3}\right) \delta 167.4,163.3,154.4$, 139.6, 134.4, $131.4(\mathrm{q}, J=32.3 \mathrm{~Hz}), 129.4,124.4,124.1(\mathrm{q}, J=272.4 \mathrm{~Hz}), 123.2,119.8(\mathrm{q}, J=3.8 \mathrm{~Hz}), 117.4$ $(\mathrm{q}, J=4.0 \mathrm{~Hz}), 114.7,67.2,57.4,53.6,36.3,26.6,25.6,22.6,22.5$.

\section{2-(3-Morpholinopropyl)- $N$-(3-(trifluoromethyl)phenyl)-5,6,7,8-tetrahydrobenzo[4,5]thieno[2,3-}

d]pyrimidin-4-amine (39b). General Procedure F. The residue was chromatographed on silica (1:99 $\mathrm{Et}_{3} \mathrm{~N}$ :EtOAc) to afford the title compound as a light brown oil which later solidified under high vacuum to give a dark white solid $(383 \mathrm{mg}, 56 \%)$. LCMS $(\mathrm{m} / \mathrm{z}): 477.2[\mathrm{M}+\mathrm{H}]^{+}$. HPLC: $t_{\mathrm{R}} 6.671 \mathrm{~min}$. HRMS $(\mathrm{m} / z)$ : $\mathrm{C}_{24} \mathrm{H}_{27} \mathrm{~F}_{3} \mathrm{~N}_{4} \mathrm{OS}$ requires $477.1937[\mathrm{M}+\mathrm{H}]^{+}$; found 477.1930. ${ }^{1} \mathrm{H} \mathrm{NMR}\left(\mathrm{CDCl}_{3}\right) \delta 8.24(\mathrm{~s}, 1 \mathrm{H}), 7.78(\mathrm{dd}, J=$ 8.2, $1.8 \mathrm{~Hz}, 1 \mathrm{H}), 7.45(\mathrm{t}, J=7.9 \mathrm{~Hz}, 1 \mathrm{H}), 7.36-7.31(\mathrm{~m}, 1 \mathrm{H}), 7.22(\mathrm{~s}, 1 \mathrm{H}), 3.70-3.66(\mathrm{~m}, 4 \mathrm{H}), 3.07(\mathrm{t}, J=$ $6.0 \mathrm{~Hz}, 2 \mathrm{H}), 2.96-2.88(\mathrm{~m}, 2 \mathrm{H}), 2.84(\mathrm{t}, J=6.0 \mathrm{~Hz}, 2 \mathrm{H}), 2.44(\mathrm{dd}, J=8.4,6.6 \mathrm{~Hz}, 6 \mathrm{H}), 2.13-1.89(\mathrm{~m}, 6 \mathrm{H})$. 
${ }^{13} \mathrm{C} \operatorname{NMR}\left(\mathrm{CDCl}_{3}\right) \delta 167.3,164.7,154.3,139.5,134.1,131.3,(\mathrm{q}, J=32.1 \mathrm{~Hz}), 129.3,124.3,124.1,(\mathrm{q}, J=$ $272.4 \mathrm{~Hz}), 123.1,119.7,(\mathrm{q}, J=3.9 \mathrm{~Hz}), 117.2$, (q, $J=4.0 \mathrm{~Hz}), 114.5,67.1,58.5,53.6,37.1,26.5,25.5,25.2$, 22.5, 22.4.

2-(4-Morpholinobutyl)- $N$-(3-(trifluoromethyl)phenyl)-5,6,7,8-tetrahydrobenzo[4,5]thieno[2,3-

d]pyrimidin-4-amine (39c). General Procedure F. The residue was chromatographed on silica (1:99 $\mathrm{Et}_{3} \mathrm{~N}$ :EtOAc) to afford the title compound as a pale yellow crystalline solid (400 mg, 59\%). LCMS $(\mathrm{m} / \mathrm{z})$ : $491.2[\mathrm{M}+\mathrm{H}]^{+}$. HPLC: $t_{\mathrm{R}} 6.671 \mathrm{~min}$. HRMS $(\mathrm{m} / \mathrm{z}): \mathrm{C}_{25} \mathrm{H}_{29} \mathrm{~F}_{3} \mathrm{~N}_{4} \mathrm{OS}$ requires $491.2102[\mathrm{M}+\mathrm{H}]^{+}$; found 491.2087. ${ }^{1} \mathrm{H} \mathrm{NMR}\left(\mathrm{CDCl}_{3}\right) \delta 8.30(\mathrm{~s}, 1 \mathrm{H}), 7.74(\mathrm{dd}, J=8.2,1.8 \mathrm{~Hz}, 1 \mathrm{H}), 7.46(\mathrm{t}, J=7.9 \mathrm{~Hz}, 1 \mathrm{H}), 7.35-$ $7.31(\mathrm{~m}, 1 \mathrm{H}), 7.22(\mathrm{~s}, 1 \mathrm{H}), 3.76-3.62(\mathrm{~m}, 4 \mathrm{H}), 3.06(\mathrm{t}, J=6.0 \mathrm{~Hz}, 2 \mathrm{H}), 2.94-2.88(\mathrm{~m}, 2 \mathrm{H}), 2.84(\mathrm{t}, J=6.0$ $\mathrm{Hz}, 2 \mathrm{H}), 2.47-2.33(\mathrm{~m}, 6 \mathrm{H}), 1.97(\mathrm{dddd}, J=23.5,21.1,13.6,8.1 \mathrm{~Hz}, 6 \mathrm{H}), 1.59(\mathrm{tt}, J=9.8,6.6 \mathrm{~Hz}, 2 \mathrm{H}) .{ }^{13} \mathrm{C}$ $\operatorname{NMR}\left(\mathrm{CDCl}_{3}\right) \delta 167.3,164.8,154.2,139.5,134.1,131.26,(\mathrm{q}, J=32.2 \mathrm{~Hz}), 129.3,124.07,(\mathrm{q}, J=272.6 \mathrm{~Hz})$, 123.0, 119.6, (q, $J=3.8 \mathrm{~Hz}), 117.19,(\mathrm{q}, J=4.0 \mathrm{~Hz}), 114.4,67.0,58.9,53.7,38.9,26.5,26.2,25.5,22.5,22.4$. $N, N$-Diethyl-2-(4-morpholinobutyl)-5,6,7,8-tetrahydrobenzo[4,5] thieno[2,3- $d]$ pyrimidin-4-amine (40). General procedure F. Pale yellow solid (145 mg, 94\%). mp: 60-62 ${ }^{\circ} \mathrm{C} . \mathrm{LCMS}(\mathrm{m} / \mathrm{z}): 403.3[\mathrm{M}+\mathrm{H}]^{+}$. HPLC: $t_{\mathrm{R}} 5.370 \mathrm{~min} . \mathrm{HRMS}(\mathrm{m} / z): \mathrm{C}_{22} \mathrm{H}_{34} \mathrm{~N}_{4} \mathrm{OS}$ requires $403.2532[\mathrm{M}+\mathrm{H}]^{+}$; found 405.2326. ${ }^{1} \mathrm{H} \mathrm{NMR}\left(\mathrm{CDCl}_{3}\right) \delta$ $3.76-3.65(\mathrm{~m}, 4 \mathrm{H}) 3.44(\mathrm{q}, J=7.0 \mathrm{~Hz}, 4 \mathrm{H}) 2.94-2.79(\mathrm{~m}, 6 \mathrm{H}) 2.45(\mathrm{~d}, J=3.8 \mathrm{~Hz}, 4 \mathrm{H}), 2.39(\mathrm{dd}, J=8.6$, $7.0 \mathrm{~Hz}, 2 \mathrm{H}), 1.96-1.88(\mathrm{~m}, 2 \mathrm{H}), 1.87-1.81(\mathrm{~m}, 2 \mathrm{H}), 1.78(\mathrm{dtd}, J=8.9,5.9,2.9 \mathrm{~Hz}, 2 \mathrm{H}), 1.63-1.52(\mathrm{~m}$, 2H), $1.12(\mathrm{t}, J=7.0 \mathrm{~Hz}, 6 \mathrm{H}) .{ }^{13} \mathrm{C} \mathrm{NMR}\left(\mathrm{CDCl}_{3}\right) \delta 168.9,163.5,162.1,132.8,127.6,119.6,66.9,58.9,53.7$, $44.8,38.8,26.8,26.5,26.1,25.9,23.2,23.1,12.6$.

2-(4-Morpholinobutyl)thieno[2,3- $d]$ pyrimidin-4(3H)-one (41). General Procedure C. The reaction vessel was decanted leaving a dark solid mass. The vessel was washed with 1,4-dioxane and the solids were collected and stirred in hot 1,4-dioxane to wash away any 1,4-dioxane soluble impurities. The crude solid was chromatographed on silica (5\% MeOH-DCM) affording the desired compound as a fluffy beige solid (1.22 $\mathrm{g}$, 57\%). LCMS (m/z): $294.2[\mathrm{M}+\mathrm{H}]^{+}$. HPLC: $t_{\mathrm{R}} 3.664 \mathrm{~min}$. HRMS $(m / z): \mathrm{C}_{14} \mathrm{H}_{19} \mathrm{~N}_{3} \mathrm{O}_{2} \mathrm{~S}$ requires $294.1277[\mathrm{M}$ $+\mathrm{H}]^{+}$; found 294.1271. ${ }^{1} \mathrm{H} \mathrm{NMR}\left(\mathrm{CDCl}_{3}\right) \delta 7.44(\mathrm{~d}, J=5.8 \mathrm{~Hz}, 1 \mathrm{H}), 7.19(\mathrm{~d}, J=5.8 \mathrm{~Hz}, 1 \mathrm{H}), 3.78-3.73(\mathrm{~m}$, $4 \mathrm{H}), 2.87(\mathrm{t}, J=7.5 \mathrm{~Hz}, 2 \mathrm{H}), 2.51-2.48(\mathrm{~m}, 2 \mathrm{H}), 2.47-2.43(\mathrm{~m}, 2 \mathrm{H}), 1.90(\mathrm{dt}, J=15.1,7.5 \mathrm{~Hz}, 2 \mathrm{H}), 1.70-$ 
$1.61(\mathrm{~m}, 2 \mathrm{H}) .{ }^{13} \mathrm{C} \mathrm{NMR}\left(\mathrm{CDCl}_{3}\right) \delta 166.0,160.1,157.8,122.3,122.2,121.4,66.4,58.1,53.4,45.8,34.4,25.3$, 25.2 .

4-(4-(4-Chlorothieno[2,3- $d$ ]pyrimidin-2-yl)butyl)morpholine (42). General Procedure D. The residue was chromatographed on silica (1:99 Et 3 N-EtOAc) which afforded the desired compound as a golden oil (485 mg, 51\%). LCMS (m/z): $312.2[\mathrm{M}+\mathrm{H}]^{+} . \mathrm{HPLC}: t_{\mathrm{R}} 4.734 \mathrm{~min} .{ }^{1} \mathrm{H} \mathrm{NMR}\left(\mathrm{CDCl}_{3}\right) \delta 7.52(\mathrm{~d}, J=6.0 \mathrm{~Hz}, 1 \mathrm{H}), 7.39$ $(\mathrm{d}, J=6.0 \mathrm{~Hz}, 1 \mathrm{H}), 3.73-3.69(\mathrm{~m}, 4 \mathrm{H}), 3.10-3.02(\mathrm{~m}, 2 \mathrm{H}), 2.46-2.42(\mathrm{~m}, 4 \mathrm{H}), 2.42-2.37(\mathrm{~m}, 2 \mathrm{H}), 1.92$ $(\mathrm{dt}, J=15.5,7.7 \mathrm{~Hz}, 2 \mathrm{H}), 1.60(\mathrm{ddd}, J=17.9,8.6,6.7 \mathrm{~Hz}, 2 \mathrm{H}) .{ }^{13} \mathrm{C} \mathrm{NMR}\left(\mathrm{CDCl}_{3}\right) \delta 169.6,166.5,154.9$, $127.2,127.1,119.9,67.1,58.9,53.9,38.9,26.7,26.3$.

2-(4-Morpholinobutyl)- $N$-(3-(trifluoromethyl)phenyl)thieno[2,3- $d]$ pyrimidin-4-amine (43a). General procedure F. The solvent was concentrated in vacuo and the brown residue was chromatographed on silica (98:1:1 EtOAc/MeOH/Et $\left.{ }_{3} \mathrm{~N}\right)$ furnishing the target compound as a transparent oil, later turning into a white powder under high vacuum $(201 \mathrm{mg}, 80 \%)$. LCMS $(\mathrm{m} / \mathrm{z}): 437.2[\mathrm{M}+\mathrm{H}]^{+}$. HPLC: $t_{\mathrm{R}} 5.670 \mathrm{~min}$. HRMS $(\mathrm{m} / \mathrm{z})$ : $\mathrm{C}_{21} \mathrm{H}_{23} \mathrm{~F}_{3} \mathrm{~N}_{4} \mathrm{OS}$ : requires 437.1621 [M+ H] $]^{+}$; found 437.1617. ${ }^{1} \mathrm{H} \mathrm{NMR}\left(\mathrm{CDCl}_{3}\right) \delta 8.33(\mathrm{t}, J=1.8 \mathrm{~Hz}, 1 \mathrm{H})$, $7.80(\mathrm{dd}, J=8.1,0.8 \mathrm{~Hz}, 1 \mathrm{H}), 7.47(\mathrm{t}, J=7.9 \mathrm{~Hz}, 1 \mathrm{H}), 7.40(\mathrm{~s}, 1 \mathrm{H}), 7.36(\mathrm{~d}, J=7.8 \mathrm{~Hz}, 1 \mathrm{H}), 7.31(\mathrm{~d}, J=6.0$ $\mathrm{Hz}, 1 \mathrm{H}), 7.25(\mathrm{~d}, J=6.0 \mathrm{~Hz}, 1 \mathrm{H}), 3.73-3.67(\mathrm{~m}, 4 \mathrm{H}), 3.00-2.94(\mathrm{~m}, 2 \mathrm{H}), 2.46-2.34(\mathrm{~m}, J=13.7,6.1 \mathrm{~Hz}$, $6 \mathrm{H}), 1.98-1.88(\mathrm{~m}, 2 \mathrm{H}), 1.64-1.55(\mathrm{~m}, 2 \mathrm{H}) .{ }^{13} \mathrm{C} \mathrm{NMR}\left(\mathrm{CDCl}_{3}\right) \delta 168.4,166.2,154.4,139.5,131.31(\mathrm{q}, J$ $=32.3 \mathrm{~Hz}), 129.4,123.9(\mathrm{q}, J=272.2 \mathrm{~Hz}), 123.4,123.3,120.0(\mathrm{q}, J=3.7 \mathrm{~Hz}), 117.6(\mathrm{q}, J=4.0 \mathrm{~Hz}), 116.6$, $114.8,67.0,58.8,53.7,39.1,26.2$.

$N, N$-Diethyl-2-(4-morpholinobutyl)thieno[2,3- $d$ ]pyrimidin-4-amine (43b). General procedure F. The solvents were evaporated under reduced pressure and the residue was chromatographed on silica (3:2 EtOAc:petroleum ether) furnishing the desired compound as a gold oil (178 mg, 89\%). LCMS (m/z): 349.2 $[\mathrm{M}+\mathrm{H}]^{+}$. HPLC: $t_{\mathrm{R}} 4.108 \mathrm{~min}$. HRMS $(\mathrm{m} / z): \mathrm{C}_{18} \mathrm{H}_{28} \mathrm{~N}_{4} \mathrm{OS}$ : requires $349.2063[\mathrm{M}+\mathrm{H}]^{+}$; found $349.2057 .{ }^{1} \mathrm{H}$ $\operatorname{NMR}\left(\mathrm{CDCl}_{3}\right) \delta 7.26(\mathrm{~d}, J=6.2 \mathrm{~Hz}, 1 \mathrm{H}), 7.09(\mathrm{~d}, J=6.2 \mathrm{~Hz}, 1 \mathrm{H}), 3.74(\mathrm{q}, J=7.1 \mathrm{~Hz}, 4 \mathrm{H}), 3.70(\mathrm{dd}, J=7.8$, $3.1 \mathrm{~Hz}, 4 \mathrm{H}), 2.81(\mathrm{t}, J=7.5 \mathrm{~Hz}, 2 \mathrm{H}), 2.44-2.41(\mathrm{~m}, 4 \mathrm{H}), 2.40-2.35(\mathrm{~m}, 2 \mathrm{H}), 1.86(\mathrm{dt}, J=15.3,7.6 \mathrm{~Hz}, 2 \mathrm{H})$, $1.58(\mathrm{tt}, J=9.8,6.6 \mathrm{~Hz}, 2 \mathrm{H}), 1.31(\mathrm{t}, J=7.0 \mathrm{~Hz}, 6 \mathrm{H}) .{ }^{13} \mathrm{C} \mathrm{NMR}\left(\mathrm{CDCl}_{3}\right) \delta 169.9,165.2,156.9,121.2,119.3$, $112.5,67.1,59.1,53.8,43.9,38.9,26.7,26.3,13.4$. 
$N, N$-diethyl-2-(morpholinomethyl)thieno[2,3-d]pyrimidin-4-amine (44). General procedure F. The solution was concentrated under reduced pressure and the residue chromatographed on silica (4:1 EtOAc: petroleum ether) affording the desired compound as a light brown oil (125 mg, 94\%). mp: 60-62 ${ }^{\circ} \mathrm{C}$. LCMS $(m / z): 262.1[\mathrm{M}+\mathrm{H}]^{+}$. HPLC: $t_{\mathrm{R}} 6.281 \mathrm{~min}$. HRMS $(\mathrm{m} / z): \mathrm{C}_{15} \mathrm{H}_{22} \mathrm{~N}_{4} \mathrm{OS}$ requires $307.1589[\mathrm{M}+\mathrm{H}]^{+}$; found 307.1587. ${ }^{1} \mathrm{H}$ NMR $\left(\mathrm{CDCl}_{3}\right) \delta 7.29(\mathrm{~d}, J=6.2 \mathrm{~Hz}, 1 \mathrm{H}), 7.15(\mathrm{~d}, J=6.2 \mathrm{~Hz}, 1 \mathrm{H}), 3.80-3.77(\mathrm{~m}, 4 \mathrm{H}), 3.76$ $(\mathrm{dd}, J=12.4,5.5 \mathrm{~Hz}, 4 \mathrm{H}), 3.71(\mathrm{~s}, 2 \mathrm{H}), 2.75-2.59(\mathrm{~m}, 4 \mathrm{H}), 1.31(\mathrm{t}, J=7.0 \mathrm{~Hz}, 3 \mathrm{H}) .{ }^{13} \mathrm{C} \mathrm{NMR}\left(\mathrm{CDCl}_{3}\right) \delta$ $169.9,160.9,156.8,121.1,120.2,113.1,66.9,65.2,53.8,44.0,13.4$.

Thieno[2,3- $d$ ]pyrimidin-4(3H)-one (45). Ethyl 2-aminothiophene-3-carboxylate (1.25 g, $7.30 \mathrm{mmol})$ was taken up in formamide $(15 \mathrm{~mL})$ and heated to $170{ }^{\circ} \mathrm{C}$ under a $\mathrm{N}_{2}$ atmosphere. The heating was continued for $5 \mathrm{~h}$, in which the progress of the reaction was monitored by LC/MS. The crude reaction mixture was diluted with EtOAc and extracted with aqueous $1 \mathrm{M} \mathrm{HCl}$ solution $(3 \times 30 \mathrm{~mL})$. The organic extracts were discarded, the aqueous phase adjusted to $\sim \mathrm{pH} 10$ and further extracted with EtOAc $(3 \times 30 \mathrm{~mL})$. The organic extracts were collected and dried over anhydrous sodium sulphate and the solvent was concentrated under reduced pressure affording the compound as a yellow solid (845 mg, 76\%). LCMS $(m / z): 153.1[\mathrm{M}+\mathrm{H}]^{+}$. HPLC: $t_{\mathrm{R}}$ 3.424 min. ${ }^{1} \mathrm{H}$ NMR $\left(d_{6}\right.$-DMSO) $\delta 12.50(\mathrm{~s}, 1 \mathrm{H}), 8.14(\mathrm{~s}, 1 \mathrm{H}),, 7.59(\mathrm{~d}, J=5.8 \mathrm{~Hz}, 1 \mathrm{H}), 7.41(\mathrm{~d}, J=5.8 \mathrm{~Hz}$, $1 \mathrm{H}) .{ }^{13} \mathrm{C}$ NMR $\left(d_{6}\right.$-DMSO) $\delta 164.6,157.9,146.1,125.1,124.3,122.1$.

4-Chlorothieno[2,3-d]pyrimidine (46). General Procedure E. The black crude residue was chromatographed on silica (60:40 EtOAc:petroleum ether) to afford the compound as a fluffy beige solid (695 mg, 77\%). LCMS $(m / z): 170.9[\mathrm{M}+\mathrm{H}]^{+} . \mathrm{HPLC}: t_{\mathrm{R}} 5.394 \mathrm{~min} .{ }^{1} \mathrm{H} \mathrm{NMR}\left(\mathrm{CDCl}_{3}\right) \delta 8.88(\mathrm{~s}, 1 \mathrm{H}), 7.64(\mathrm{~d}, J=6.0 \mathrm{~Hz}, 1 \mathrm{H}), 7.46$ $(\mathrm{d}, J=6.0 \mathrm{~Hz}, 1 \mathrm{H}) .{ }^{13} \mathrm{C} \mathrm{NMR}\left(\mathrm{CDCl}_{3}\right) \delta 168.8,155.0,152.8,129.6,128.4,119.2$.

$N$-(3-(trifluoromethyl)phenyl)thieno[2,3-d]pyrimidin-4-amine (47a). General procedure F. The solvent was evaporated under reduced pressure and the residue was chromatographed on silica (70:29:1 petroleum ether:EtOAc:Et $\left.{ }_{3} \mathrm{~N}\right)$. This afforded the target compound as a white/pale yellow solid (225 mg, 65\%). mp: 60$62{ }^{\circ} \mathrm{C}$. LCMS $(\mathrm{m} / \mathrm{z}): 296.0[\mathrm{M}+\mathrm{H}]^{+}$. HPLC: $t_{\mathrm{R}} 6.842 \mathrm{~min}$. HRMS $(\mathrm{m} / \mathrm{z}): \mathrm{C}_{13} \mathrm{H}_{8} \mathrm{~F}_{3} \mathrm{~N}_{3} \mathrm{~S}$ requires $296.0466[\mathrm{M}$ $+\mathrm{H}]^{+}$; found 296.0464. ${ }^{1} \mathrm{H} \mathrm{NMR}\left(400 \mathrm{MHz}, d_{6}\right.$-DMSO) $\delta 9.92(\mathrm{~s}, 1 \mathrm{H}), 8.60(\mathrm{~s}, 1 \mathrm{H}), 8.33(\mathrm{t}, J=2.0 \mathrm{~Hz}, 1 \mathrm{H})$, $8.23(\mathrm{dd}, J=8.1,2.0 \mathrm{~Hz}, 1 \mathrm{H}), 7.93(\mathrm{~d}, J=6.0 \mathrm{~Hz}, 1 \mathrm{H}), 7.80(\mathrm{~d}, J=6.0 \mathrm{~Hz}, 1 \mathrm{H}), 7.63(\mathrm{t}, J=8.0 \mathrm{~Hz}, 1 \mathrm{H}), 7.44$ 
$(\mathrm{ddt}, J=7.8,1.7,0.9 \mathrm{~Hz}, 1 \mathrm{H}) .{ }^{13} \mathrm{C}$ NMR $\left(d_{6}\right.$-DMSO) $\delta 166.8,154.5,152.9,140.3,129.7,129.3(\mathrm{~d}, J=31.5$ $\mathrm{Hz}), 124.5,124.3(\mathrm{q}, J=272.6 \mathrm{~Hz}), 119.4,119.2(\mathrm{q}, J=3.7 \mathrm{~Hz}), 117.2,116.9(\mathrm{q}, J=4.0 \mathrm{~Hz})$.

$N, N$-diethylthieno[2,3-d]pyrimidin-4-amine (47b). General procedure $\mathrm{F}$. The bright blue crude reaction was evaporated of any volatile solvents and the resulting residue chromatographed on silica (50:50 petroleum ether:EtOAc) affording the compound as a light green powder $(223 \mathrm{mg}, 91 \%)$. LCMS $(\mathrm{m} / \mathrm{z}): 208.1[\mathrm{M}+\mathrm{H}]^{+}$. HPLC: $t_{\mathrm{R}} 4.098 \mathrm{~min}$. HRMS $(\mathrm{m} / \mathrm{z}): \mathrm{C}_{10} \mathrm{H}_{13} \mathrm{~N}_{3} \mathrm{~S}$ : requires $208.0984[\mathrm{M}+\mathrm{H}]^{+}$; found 208.0903. ${ }^{1} \mathrm{H} \mathrm{NMR}$ $\left(\mathrm{CDCl}_{3}\right) \delta 8.43(\mathrm{~s}, 1 \mathrm{H}), 7.32(\mathrm{~d}, J=6.2 \mathrm{~Hz}, 1 \mathrm{H}), 7.19(\mathrm{~d}, J=6.2 \mathrm{~Hz}, 1 \mathrm{H}), 3.76(\mathrm{q}, J=7.1 \mathrm{~Hz}, 4 \mathrm{H}), 1.33(\mathrm{t}, J$ $=7.1 \mathrm{~Hz}, 6 \mathrm{H}) .{ }^{13} \mathrm{C} \mathrm{NMR}\left(\mathrm{CDCl}_{3}\right) \delta 169.1,157.1,153.1,121.4,120.5,114.8,44.1,13.3$.

Pharmacological Characterisation. Materials. Dulbecco's modified Eagle's medium, Flp-In CHO cells, and hygromycin B were purchased from Invitrogen (Carlsbad, CA). Fetal bovine serum (FBS) was purchased from ThermoTrace (Melbourne, VIC, Australia). $\left[{ }^{3} \mathrm{H}\right]$ raclopride, GF/C 96-well filter plates, and MicroScint0 were from PerkinElmer (Boston, MA). All other reagents were purchased from Sigma Aldrich (St. Louis, MO).

Cell culture. FlpIn Chinese Hamster Ovary (CHO) cells (Invitrogen, Carlsbad, CA, USA) stably expressing the $\mathrm{hD}_{2 \mathrm{~L}} \mathrm{R}$ were grown and maintained in Dulbecco's modified Eagle's medium (DMEM) supplemented with $10 \%$ fetal bovine serum (FBS), and $200 \mu \mathrm{g} / \mathrm{mL}$ of Hygromycin-B, and maintained at 37 ${ }^{\circ} \mathrm{C}$ in a humidified incubator containing $5 \% \mathrm{CO}_{2}$.

$\left[{ }^{3} H\right]$ Raclopride Binding Assay: The membranes of FlpIn CHO cells expressing the $\mathrm{hD}_{2 \mathrm{~L}} \mathrm{R}$ were prepared as previously described. ${ }^{38}$ Radioligand inhibition assays were performed by co-incubating membrane homogenates (15 $\mu \mathrm{g}$ protein) with varying concentrations of test compound in binding buffer (20 mM HEPES, $100 \mathrm{mM} \mathrm{NaCl}, 6 \mathrm{mM} \mathrm{MgCl} 2,1 \mathrm{mM}$ EGTA, $1 \mathrm{mM}$ EDTA; $\mathrm{pH} 7.4)$ containing $0.5 \mathrm{nM}$ of $\left[{ }^{3} \mathrm{H}\right]$ raclopride to a final volume of $300 \mu \mathrm{L}$ in the absence or presence of the competing compounds, and incubated at $25^{\circ} \mathrm{C}$ for 2-3 h. Each test compound was dissolved in dimethyl sulfoxide and diluted in the binding buffer into 10 half${ }^{10} \log$ serial dilutions: final test concentrations ranged from $10^{-3} \mathrm{M}$ to $10^{-7} \mathrm{M}$. All compound concentrations were tested in duplicate. Nonspecific binding was determined using $10 \mu \mathrm{M}$ haloperidol (Sigma-Aldrich, St. Louis, MO. In the kinetic binding assay, the dissociation of $\left[{ }^{3} \mathrm{H}\right]$ raclopride was started after being incubated 
for 60 minutes. Binding was terminated by fast flow filtration over GF/C membrane unifilter plates (PerkinElmer) using a Uniplate 96-well harvester (PerkinElmer) followed by five washes with ice-cold $0.9 \%$ $\mathrm{NaCl}$. MicroScint-0 (50 $\mu \mathrm{L} /$ well) was added, plates were sealed (TopSeal ${ }^{\mathrm{TM}}$ ), and radioactivity was measured in a MicroBeta2 LumiJET MicroBeta counter (PerkinElmer). The affinity $\left(K_{\mathrm{d}}\right)$ of $\left[{ }^{3} \mathrm{H}\right]$ raclopride at the $\mathrm{D}_{2 \mathrm{~L}} \mathrm{R}$ determined in saturation binding assays is $1.07 \pm 0.12 \mathrm{nM}$ and the $B_{\max }$ value is $1.51 \pm 0.26 \mathrm{pmol} / \mathrm{mg}$ protein. Cell culture and transfection for cAMP assay: FlpIn CHO cells stably expressing the human dopamine $\mathrm{D}_{2 \mathrm{~L}}$ receptor were maintained in DMEM supplemented with $5 \%$ foetal calf serum (FBS) and $0.2 \mathrm{mg} / \mathrm{mL}$ hygromycin at $37{ }^{\circ} \mathrm{C}$ in a humidified incubator supplied with $5 \% \mathrm{CO}_{2}$. For transfection, the cells were grown in $10 \mathrm{~cm}$ culture dishes until sub-confluent. A mixture of $4 \mu \mathrm{g}$ plasmid DNA containing BRET-based cAMP (CAMYEL) biosensor construct ${ }^{29}$ and $25 \mu \mathrm{g} 20 \mathrm{kDa}$ linear polyethylene imine (PEI) in $500 \mu \mathrm{L} 150 \mathrm{mM} \mathrm{NaCl}$ was added into a dish of cells.

cAMP measurement: The cellular cAMP levels were measured with the CAMYEL BRET-based biosensor for cAMP. ${ }^{29}$ One day after transfection, cells were trypsinised and seeded in white 96-well microplates. The cells were then cultured for an additional day, rinsed twice with Hank's Balanced Salt Solution (HBSS) and were then incubated in fresh HBSS. The Renilla luciferase (RLuc) substrate coelenterazine-h was added to reach a final concentration of $5 \mu \mathrm{M}$. The cells were stimulated with dopamine in the presence of $10 \mu \mathrm{M}$ forskolin (final concentration). For the antagonism assay, the antagonists were added 30 min prior to stimulation. The BRET signals were measured using a BMG Lumistar counter 30 min after stimulation. The BRET signal (BRET ratio) was determined by calculating the ratio of the light emitted at 535 $\pm 30 \mathrm{~nm}$ (YFP) to the light emitted at $475 \pm 30 \mathrm{~nm}$ (RLuc).

Data analysis. Computerized nonlinear regression, statistical analyses and simulations were performed using Prism 6.0 (GraphPad Prism 6.0b Software, San Diego, CA).

\section{Analysis of radioligand binding experiments:}

Competition-binding curves between $\left[{ }^{3} \mathrm{H}\right]$ raclopride and $\mathbf{1}$ and analogues of $\mathbf{1}$ were fitted to the allosteric ternary complex model using the following equation. ${ }^{27}$

$$
Y=\frac{\frac{[A]}{K_{\mathrm{A}}}}{\frac{[A]}{\mathrm{A} \mathrm{SS}_{\mathrm{A}} \mathrm{Par}}+\left(\frac{1+\frac{[B]}{K_{\mathrm{B}}}}{\mathrm{gon} \mathrm{P}^{|c|\left[\frac{[B]}{K_{\mathrm{B}}}\right.}}\right)}
$$


where $\mathrm{Y}$ is percentage (vehicle control) binding; $[\mathrm{A}]$ and $[\mathrm{B}]$ are the concentrations of $\left[{ }^{3} \mathrm{H}\right]$ raclopride and modulator, respectively; $K_{A}$ and $K_{B}$ are the equilibrium dissociation constants of $\left[{ }^{3} \mathrm{H}\right]$ raclopride and modulator, respectively; and $\alpha$ is the cooperativity between $\left[{ }^{3} \mathrm{H}\right]$ raclopride and modulator. Values of $\alpha>1$ denote positive cooperativity, values $<1$ (but $>0$ ) denote negative cooperativity and values $=1$ denote neutral cooperativity. For analogues of 1 that displayed incomplete displacement of $\left[{ }^{3} \mathrm{H}\right]$ raclopride, a value of $\alpha$ could be determined experimentally. However, for analogues that acted to completely displace the radioligand then we could not distinguish an allosteric mode of action (with high negative cooperativity) from a competitive mode of interaction. In these cases, we fit the above model fixing the value of $\alpha$ to assume high negative cooperativity $(\alpha=0.0001)$. Values of $K_{\mathrm{B}}$ determined using this fit did not deviate significantly from values of affinity derived using a competitive model.

Radioligand binding dissociation kinetic data was analysed and fit to an exponential decay equation using non-linear regression to determine the rate constant.

$$
\text { Total Binding }=\mathrm{NS}+(\text { Total }-\mathrm{NS}) \times e^{-k_{o f f} t}
$$

Where NS is non-specific binding and $\mathrm{t}$ is time expressed in minutes. The dissociation rate constant $\left(k_{\mathrm{off}}\right)$ is expressed in units of inverse, $\min ^{-1-}$. The half-life for dissociation is also calculated as $\ln (2) / k_{\text {off }}$ or $0.6931 / k_{\text {off. }}$

Analysis of functional data. All concentration-response data were fitted to the following modified fourparameter Hill equation to derive potency estimates. ${ }^{39}$

$$
E=\text { Basal }+\frac{\left(E_{\max }-\text { Basal }\right) \cdot[A]^{n H}}{\left[A^{n H}\right]+E C_{50}^{n H}}
$$


where $\mathrm{E}$ is the effect of the system, $\mathrm{nH}$ is the Hill slope and $\mathrm{EC}_{50}$ is the concentration of agonist $[A]$ that gives the midpoint response between basal and maximal effect of dopamine or other agonists $\left(E_{\max }\right)$, which are the lower and upper asymptotes of the response, respectively.

To determine the mode of interaction of $\mathbf{1}$ and derivaites of $\mathbf{1}$ at the $\mathrm{D}_{2} \mathrm{R}$ in relation to the agonist dopamine, data were fit to both a competitive and allosteric model and the best fit compared statistically. A logistic equation of competitive agonist-antagonist interaction was globally fitted to data from functional experiments measuring the interaction between dopamine and all analogues of $\mathbf{1}$ :

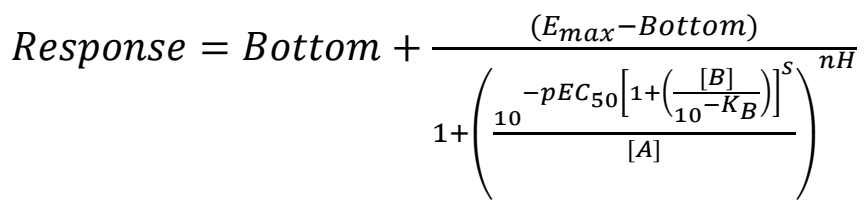

Where $s$ represents the Schild slope for the antagonist and $\mathrm{p} A_{2}$ represents the negative logarithm of the molar concentration of antagonist that makes it necessary to double the concentration of agonist needed to elicit the original submaximal response obtained in the absence of antagonist. The same data describing the interaction between all analogues of $\mathbf{1}$ and dopamine were also analyzed using a complete operational model of allosterism and agonism according to equation $5::^{27}$

$E=\frac{E_{m}\left(\tau_{A}[A]\left(K_{B}+\alpha \beta[B]\right)+\tau_{B}[B] K_{A}\right)^{n H}}{\left([A] K_{B}+K_{A} K_{B}+K_{A}[B]+\alpha[A][B]\right)^{n H}+\left(\tau_{A}[A]\left(K_{B}+\alpha \beta[B]\right)+\tau_{B}[B] K_{A}\right)^{n H}}$

Where $E_{m}$ is the maximum possible cellular response, $[\mathrm{A}]$ and $[\mathrm{B}]$ are the concentrations of orthosteric and allosteric ligands, respectively, $K_{\mathrm{A}}$ and $K_{\mathrm{B}}$ are the equilibrium dissociation constant of the orthosteric and allosteric ligands, respectively, $\tau_{\mathrm{A}}$ and $\tau_{\mathrm{B}}$ (constrained to -100) are operational measures of orthosteric and allosteric ligand efficacy (which incorporate both signal efficiency and receptor density), respectively, $\alpha$ is the binding cooperativity parameter between the orthosteric and allosteric ligand, and $\beta$ denotes the magnitude of 
the allosteric effect of the modulator on the efficacy of the orthosteric agonist. $K_{\mathrm{A}}$ was constrained to $617 \mathrm{nM}$, and represents a value of functional affinity determined by an operational model of agonism applied to doseresponse data of dopamine in the presence of increasing concentrations of the alkylating agent phenoxybenzamine. For compounds that caused a limited rightward shift of the dopamine dose-response curve but no decrease in $\mathrm{E}_{\max }$, data were fit using an operational model of allosterism where $\log \beta$ was constrained to 0 to represent neutral cooperativity with dopamine efficacy. For compounds that produced an unlimited decrease in the maximal response of dopamine $\log \beta$ was constrained to -100 .

For each of the compounds the two equations (models) were then compared for their fit using an extrasum-of-squares $F$ test. All of the data points and values shown in the figures and tables are the mean \pm s.e.m. of at least three separate experiments performed in duplicate unless otherwise stated.

Molecular Docking Simulations. The $\mathrm{D}_{2} \mathrm{R}$ crystal structure (PDB ID 6C 38$)^{32}$ was prepared by the regularisation algorithm implemented in ICM-Pro molecular modeling software. ${ }^{40}$ Raclopride was docked into the orthosteric pocket of the $\mathrm{D}_{2} \mathrm{R}$ using an energy-based docking protocol implemented in the ICM-Pro software. ${ }^{40}$ The best energy binding pose predicted for raclopride in the $\mathrm{D}_{2} \mathrm{R}$ was found to be similar to the binding pose of closely related eticlopride in the co-crystallised complex with the $\mathrm{D}_{3} \mathrm{R}$. ${ }^{42}$ The $\mathrm{D}_{2} \mathrm{R}$-raclopride complex was further optimised using Biased Probability Monte Carlo (BPMC) optimisation of the surrounding residues in the proximity of $5 \AA$ of ligand. In the final $\mathrm{D}_{2} \mathrm{R}$-raclopride complex, the RMSD between common atoms of raclopride and the crystallographic pose of eticlopride did not exceed $0.5 \AA$.

Compound 1 and its thirty-three analogues were docked into the $\mathrm{D}_{2} \mathrm{R}$-raclopride complex using an energybased docking protocol implemented in the ICM-Pro software. ${ }^{40,41}$ Compounds were generated from 2D representations and their 3D geometry was optimised using MMFF-94 force field. The docking was performed in the rectangular box that comprised the whole extracellular part of the receptor above raclopride, including the extracellular loops. Docking simulations used BPMC optimisation of the compounds internal coordinates in the pre-calculated grid energy potentials of the receptor. The exhaustive sampling of the compound conformational space was done with the thoroughness parameter set to 10, and at least three independent 
docking runs performed for each compound. The final docking poses were selected based on optimal ligand receptor interactions and ICM binding scores.

For $\mathrm{D}_{3} \mathrm{R}$ docking, we used the previously published $\mathrm{D}_{3} \mathrm{R}$-eticlopride crystal structure (PDB ID: 3PBL) ${ }^{9}$, where raclopride was docked in place of eticlopride. Compound $\mathbf{1}$ and its eight analogues were then docked into $\mathrm{D}_{3} \mathrm{R}$-raclopride complex. Due to the hypothesised high flexibility of the $\mathrm{E} 90^{2.65}$ residue side chain, it was set up as "explicitly flexible group" during the docking. Further docking method was used as abovementioned.

\section{- ASSOCIATED CONTENT}

\section{Supporting Information}

Coordinates for computational models ( $\mathrm{D}_{2} \mathrm{R}$ PDB ID: 6C38) and molecular formula strings (CSV) have been included in Supporting Information. Authors will release the atomic coordinates and experimental data upon article publication.

\section{- AUTHOR INFORMATION}

\section{Corresponding Authors}

*J.R.L.: phone, +61 39903 9095; e-mail, rob.lane@ monash.edu

*B.C.: phone, +61 9903 9556; e-mail, ben.capuano@ monash.edu

\section{Author Contributions}

Notes The authors declare no competing financial interest.

\section{- ACKNOWLEDGMENTS}

This research was supported by a National Health and Medical Research Council (NHMRC) Project Grant Number APP1049564. 


\section{- ABBREVIATION LIST}

cAMP, cyclic adenosine monophosphate; $\mathrm{D}_{2} \mathrm{R}$, dopamine $\mathrm{D}_{2}$ receptor; $\mathrm{D}_{3} \mathrm{R}$, dopamine $\mathrm{D}_{3}$ receptor; dopamine, DA; GPCR, G protein-coupled receptor; FGA, first-generation antipsychotic; SGA, second-generation antipsychotic; EPS, extrapyramidal symptoms; NAM, negative allosteric modulator; VLS, virtual ligand screening; SAR, structure-activity relationship; $\mathrm{CHO}$, chinese hampster ovary; cAMP, cyclic adenosine monophosphate; BRET, bioluminescence resonance energy transfer; FBS, foetal bovine serum; HBSS, hank's balanced salt solution; SEM, standard error of mean; DMF, $N, N$-dimethylformamide, $\mathrm{POCl}_{3}$, phosphorus oxychloride; $i$-PrOH, isopropyl alcohol; EtOAc, ethyl acetate; DCM, dichloromethane; MWI, microwave irradiation; TRIDENT, tris[2-(2-methoxyethoxy)ethyl]amine.

\section{- REFERENCES}

1. Seeman, P. Targeting the dopamine D2 receptor in schizophrenia. Expert Opin. Ther. Targets 2006, $10,515-531$.

2. Davis, K. L.; Kahn, R. S.; Ko, G.; Davidson, M. Dopamine in schizophrenia: a review and reconceptualization. Am. J. Psychiatry 1991, 148, 1474-1486.

3. Boyd, K. N.; Mailman, R. B. Dopamine receptor signaling and current and future antipsychotic drugs. Handb. Exp. Pharmacol. 2012, 212, 53-86.

4. Newcomer, J. W. Second-generation (atypical) antipsychotics and metabolic effects: a comprehensive literature review. CNS Drugs 2005, 19, 1-93.

5. Rossi, M.; Fasciani, I.; Marampon, F.; Maggio, R.; Scarselli, M. The first negative allosteric modulator for dopamine D2 and D3 Receptors, SB269652 may lead to a new generation of antipsychotic drugs. Mol. Pharmacol. 2017, 91, 586-594.

6. Kenakin, T.; Miller, L. J. Seven transmembrane receptors as shapeshifting proteins: the impact of allosteric modulation and functional selectivity on new drug discovery. Pharmacol. Rev. 2010, 62, 265-304. 7. May, L. T.; Christopoulos, A. Allosteric modulators of G-protein-coupled receptors. Curr. Opin. Pharmacol. 2003, 3, 551-556. 
8. Lane, J. R.; Chubukov, P.; Liu, W.; Canals, M.; Cherezov, V.; Abagyan, R.; Stevens, R. C.; Katritch, V. Structure-based ligand discovery targeting orthosteric and allosteric pockets of dopamine receptors. Mol. Pharmacol. 2013, 84, 794-807.

9. $\quad$ Chien, E. Y.; Liu, W.; Zhao, Q.; Katritch, V.; Han, G. W.; Hanson, M. A.; Shi, L.; Newman, A. H.; Javitch, J. A.; Cherezov, V.; Stevens, R. C. Structure of the human dopamine D3 receptor in complex with a D2/D3 selective antagonist. Science 2010, 330, 1091-1095.

10. Silvano, E.; Millan, M. J.; Mannoury la Cour, C.; Han, Y.; Duan, L.; Griffin, S. A.; Luedtke, R. R.; Aloisi, G.; Rossi, M.; Zazzeroni, F.; Javitch, J. A.; Maggio, R. The tetrahydroisoquinoline derivative SB269,652 is an allosteric antagonist at dopamine D3 and D2 receptors. Mol. Pharmacol. 2010, 78, 925934.

11. Wood, M.; Ates, A.; Andre, V. M.; Michel, A.; Barnaby, R.; Gillard, M. In vitro and in vivo identification of novel positive allosteric modulators of the human dopamine D2 and D3 receptor. Mol. Pharmacol. 2016, 89, 303-312.

12. Kumar, V.; Moritz, A. E.; Keck, T. M.; Bonifazi, A.; Ellenberger, M. P.; Sibley, C. D.; Free, R. B.; Shi, L.; Lane, J. R.; Sibley, D. R.; Newman, A. H. Synthesis and pharmacological characterization of novel trans-cyclopropylmethyl-linked bivalent ligands that exhibit selectivity and allosteric pharmacology at the dopamine D3 receptor (D3R). J. Med. Chem. 2017, 60, 1478-1494.

13. Manglik, A.; Lin, H.; Aryal, D. K.; McCorvy, J. D.; Dengler, D.; Corder, G.; Levit, A.; Kling, R. C.; Bernat, V.; Hubner, H.; Huang, X. P.; Sassano, M. F.; Giguere, P. M.; Lober, S.; Da, D.; Scherrer, G.; Kobilka, B. K.; Gmeiner, P.; Roth, B. L.; Shoichet, B. K. Structure-based discovery of opioid analgesics with reduced side effects. Nature 2016, 537, 185-190.

14. Carlsson, J.; Coleman, R. G.; Setola, V.; Irwin, J. J.; Fan, H.; Schlessinger, A.; Sali, A.; Roth, B. L.; Shoichet, B. K. Ligand discovery from a dopamine D3 receptor homology model and crystal structure. Nat. Chem. Biol. 2011, 7, 769-778.

15. Sabnis, R. W.; Rangnekar, D. W.; Sonawane, N. D. 2-Aminothiophenes by the gewald reaction. $J$. Heterocyclic Chem. 1999, 36, 333-345. 
16. Bogolubsky, A. V.; Ryabukhin, S. V.; Stetsenko, S. V.; Chupryna, A. A.; Volochnyuk, D. M.; Tolmachev, A. A. Synthesis of thieno[2,3-d]pyrimidin-2-ylmethanamine combinatorial library with four diversity points. J. Comb. Chem. 2007, 9, 661-667.

17. Bozorov, K.; Zhao, J. Y.; Elmuradov, B.; Pataer, A.; Aisa, H. A. Recent developments regarding the use of thieno[2,3- $d]$ pyrimidin-4-one derivatives in medicinal chemistry, with a focus on their synthesis and anticancer properties. Eur. J. Med. Chem. 2015, 102, 552-573.

18. Wilding, B.; Faschauner, S.; Klempier, N. A practical synthesis of 5-functionalized thieno[2,3d]pyrimidines. Tetrahedron Lett. 2015, 56, 4486-4489.

19. Wu, C.-H.; Coumar, M. S.; Chu, C.-Y.; Lin, W.-H.; Chen, Y.-R.; Chen, C.-T.; Shiao, H.-Y.; Rafi, S.; Wang, S.-Y.; Hsu, H.; Chen, C.-H.; Chang, C.-Y.; Chang, T.-Y.; Lien, T.-W.; Fang, M.-Y.; Yeh, K.-C.; Chen, C.-P.; Yeh, T.-K.; Hsieh, S.-H.; Hsu, J. T. A.; Liao, C.-C.; Chao, Y.-S.; Hsieh, H.-P. Design and synthesis of tetrahydropyridothieno[2,3- $d]$ pyrimidine scaffold based epidermal growth factor receptor (EGFR) kinase inhibitors: the role of side chain chirality and michael acceptor group for maximal potency. J. Med. Chem. 2010, 53, 7316-7326.

20. Hesse, S.; Perspicace, E.; Kirsch, G. Microwave-assisted synthesis of 2-aminothiophene-3carboxylic acid derivatives, 3H-thieno[2,3- $d]$ pyrimidin-4-one and 4-chlorothieno[2,3-d]pyrimidine. Tetrahedron Lett. 2007, 48, 5261-5264.

21. Bugge, S.; Kaspersen, S. J.; Sundby, E.; Hoff, B. H. Route selection in the synthesis of C-4 and C-6 substituted thienopyrimidines. Tetrahedron 2012, 68, 9226-9233.

22. Jang, M.-Y.; Jonghe, S. D.; Belle, K. V.; Louat, T.; Waer, M.; Herdewijn, P. Synthesis, immunosuppressive activity and structure-activity relationship study of a new series of 4- $\mathrm{N}$-piperazinylthieno[2,3-d]pyrimidine analogues. Bioorg. Med. Chem. Lett. 2010, 20, 844-847.

23. Forero, J. S. B.; Carvalho, E. M. d.; J., J. J.; Silva, F. M. d. A new protocol for the synthesis of 2aminothiophenes through the Gewald reaction in solvent-free conditions. Heterocycl. Lett. 2011, 1, 1-67.

24. Baricordi, N.; Benetti, S.; Bertolasi, V.; De Risi, C.; Pollini, G. P.; Zamberlan, F.; Zanirato, V. 1,4Dithiane-2,5-diol as an efficient synthon for a straightforward synthesis of functionalized 
tetrahydrothiophenes via sulfa-Michael/aldol-type reactions with electrophilic alkenes. Tetrahedron 2012, $68,208-213$.

25. Lilienkampf, A.; Karkola, S.; Alho-Richmond, S.; Koskimies, P.; Johansson, N.; Huhtinen, K.; Vihko, K.; Wähälä, K. Synthesis and biological evaluation of $17 \beta$-hydroxysteroid dehydrogenase type 1 (17 $\beta$-HSD1) inhibitors based on a thieno[2,3-d]pyrimidin-4(3H)-one core. J. Med. Chem. 2009, 52, 66606671.

26. Shonberg, J.; Draper-Joyce, C.; Mistry, S. N.; Christopoulos, A.; Scammells, P. J.; Lane, J. R.; Capuano, B. Structure-activity study of $N$-((trans)-4-(2-(7-cyano-3,4-dihydroisoquinolin-2(1H)yl)ethyl)cyclohexyl)-1H-ind ole-2-carboxamide (SB269652), a bitopic ligand that acts as a negative allosteric modulator of the dopamine D2 receptor. J. Med. Chem. 2015, 58, 5287-5307.

27. Christopoulos, A.; Kenakin, T. G protein-coupled receptor allosterism and complexing. Pharmacol. Rev. 2002, 54, 323-374.

28. Christopoulos, A.; Changeux, J. P.; Catterall, W. A.; Fabbro, D.; Burris, T. P.; Cidlowski, J. A.; Olsen, R. W.; Peters, J. A.; Neubig, R. R.; Pin, J. P.; Sexton, P. M.; Kenakin, T. P.; Ehlert, F. J.; Spedding, M.; Langmead, C. J. International Union of Basic and Clinical Pharmacology. XC. multisite pharmacology: recommendations for the nomenclature of receptor allosterism and allosteric ligands. Pharmacol. Rev. 2014, 66, 918-947.

29. Jiang, L. I.; Collins, J.; Davis, R.; Lin, K. M.; DeCamp, D.; Roach, T.; Hsueh, R.; Rebres, R. A.; Ross, E. M.; Taussig, R.; Fraser, I.; Sternweis, P. C. Use of a cAMP BRET sensor to characterize a novel regulation of cAMP by the sphingosine 1-phosphate/G13 pathway. J. Biol. Chem. 2007, 282, 10576-10584. 30. Leach, K.; Sexton, P. M.; Christopoulos, A. Allosteric GPCR modulators: taking advantage of permissive receptor pharmacology. Trends Pharmacol. Sci. 2007, 28, 382-389.

31. Christopoulos, A. Assessing the distribution of parameters in models of ligand-receptor interaction: to log or not to log. Trends Pharmacol. Sci. 1998, 19, 351-357.

32. Wang, S.; Che, T.; Levit, A.; Shoichet, B. K.; Wacker, D.; Roth, B. L. Structure of the D2 dopamine receptor bound to the atypical antipsychotic drug risperidone. Nature 2018, 555, 269-273. 
33. Nirogi, R. V. S.; Kambhampati, R. S.; Kothmirkar, P.; Arepalli, S.; Pamuleti, N. R. G.; Shinde, A. K.; Dubey, P. K. Convenient and efficient synthesis of some novel fused thieno pyrimidines using gewald's reaction. Synth. Commun. 2011, 41, 2835-2851.

34. Rashmi, P.; Nargund, L. V.; Hazra, K.; Chandra, J. N. Thienopyrimidines as novel inhibitors of Mycobacterium tuberculosis: synthesis and in-vitro studies. Arch. Pharm. 2011, 344, 459-465.

35. Brindani, N.; Rassu, G.; Dell'Amico, L.; Zambrano, V.; Pinna, L.; Curti, C.; Sartori, A.; Battistini, L.; Casiraghi, G.; Pelosi, G.; Greco, D.; Zanardi, F. Organocatalytic, asymmetric eliminative [4+2] cycloaddition of allylidene malononitriles with enals: rapid entry to cyclohexadiene-embedding linear and angular polycycles. Angew. Chem. Int. Ed. 2015, 54, 7386-7390.

36. Frankel, M.; Mosher, H. S.; Whitmore, F. C. Addition reactions of 1-cyano-1,3-butadiene. J. Am. Chem. Soc. 1950, 72, 81-83.

37. Shibinskaya, M. O.; Kutuzova, N. A.; Mazepa, A. V.; Lyakhov, S. A.; Andronati, S. A.; Zubritsky, M. J.; Galat, V. F.; Lipkowski, J.; Kravtsov, V. C. Synthesis of 6-aminopropyl-6H-indolo[2,3-b]quinoxaline Derivatives. J. Heterocylic Chem. 2012, 49, 678-682.

38. Klein Herenbrink, C.; Sykes, D. A.; Donthamsetti, P.; Canals, M.; Coudrat, T.; Shonberg, J.; Scammells, P. J.; Capuano, B.; Sexton, P. M.; Charlton, S. J.; Javitch, J. A.; Christopoulos, A.; Lane, J. R. The role of kinetic context in apparent biased agonism at GPCRs. Nat. Commun. 2016, 7, 10842.

39. Motulsky, H. J. C. Fitting models to biological data using linear and nonlinear regression: a practical guide to curve fitting. In Graphpad Software Inc., San Diego CA.: 2003.

40. Neves, M. A. C.; Totrov, M.; Abagyan, R. Docking and scoring with ICM: the benchmarking results and strategies for improvement. J. Comput. Aided Mol. Des. 2012, 26, 675-686.

41. Abagyan, R., Orry, A., Rausch, E. \& Totrov, M. ICM Manual MolSoft LLC, La Jolla, CA, 2017. 


\section{Table of Contents graphic}

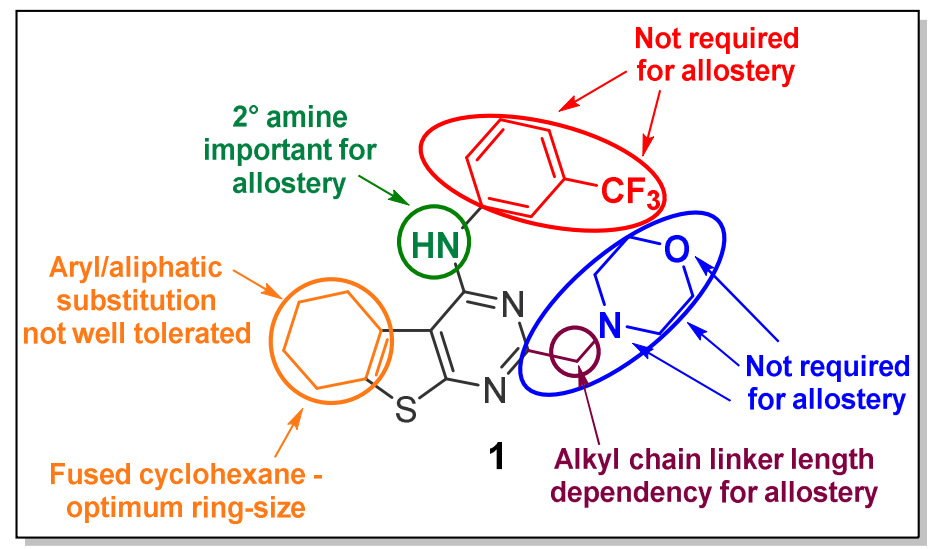

